\title{
Hydrogeology and Ground-Water Quality of Glacial-Drift Aquifers, Leech Lake Indian Reservation, North-Central Minnesota
}

By Richard J. Lindgren

U.S. Geological Survey

Water-Resources Investigations Report 95-4077

Prepared in cooperation with the

Leech Lake Indian Reservation Business Committee

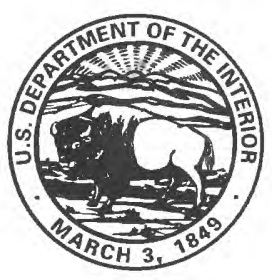

Mounds View, Minnesota 1996 


\section{U.S. DEPARTMENT OF THE INTERIOR \\ BRUCE BABBITT, Secretary \\ U.S. GEOLOGICAL SURVEY \\ Gordon P. Eaton, Director}

For additional information write to:

Copies of this report can be purchased from:

U.S. Geological Survey

Earth Science Information Center

District Chief

U.S. Geological Survey

Open-File Reports Section

2280 Woodale Drive

Box 25286, MS 517

Mounds View, MN 55112

Denver Federal Center

Denver, CO 80225 


\section{Contents}

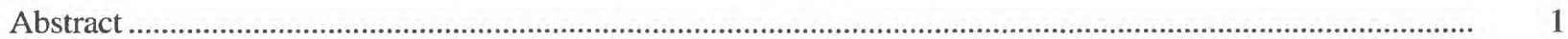

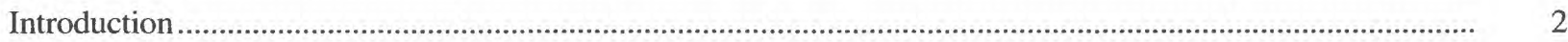

Purpose and scope

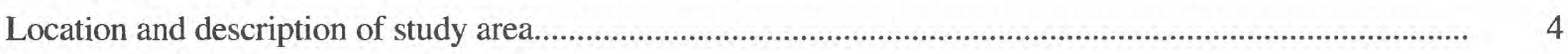

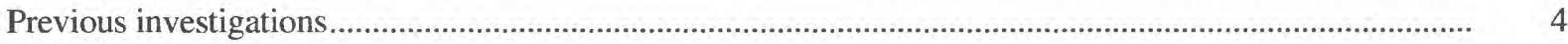

Methods of investigation .............................................................................................................

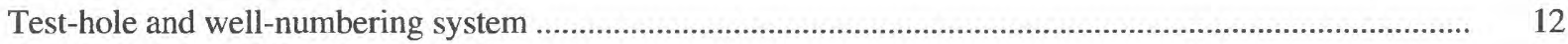

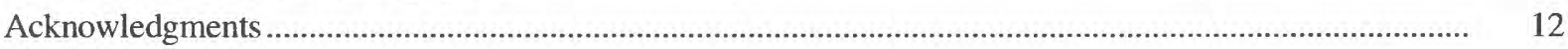

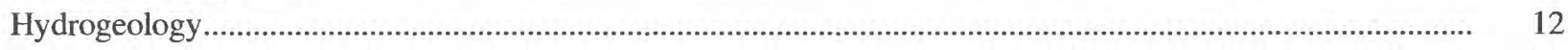

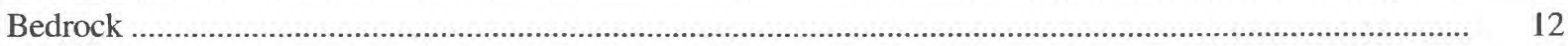

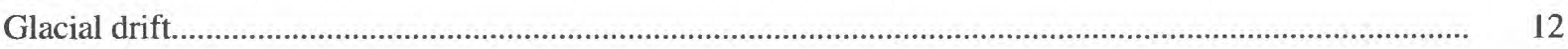

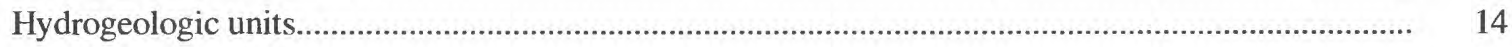

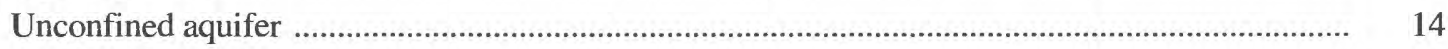

Uppermost confining unit ..................................................................................................... 20

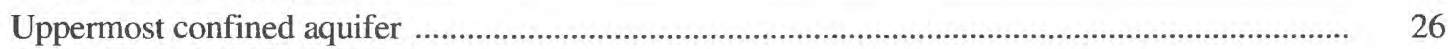

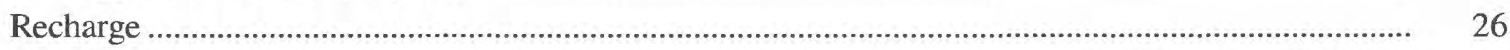

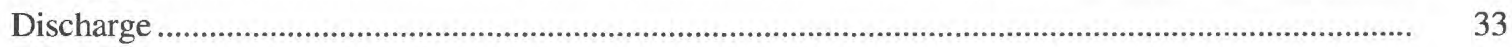

Ground-water discharge to streams, lakes, and wetlands .......................................................... 33

Ground-water evapotranspiration ............................................................................................. 36

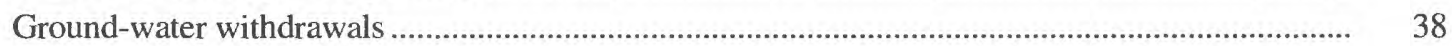

Conceptual model of ground-water flow ..................................................................................... 38

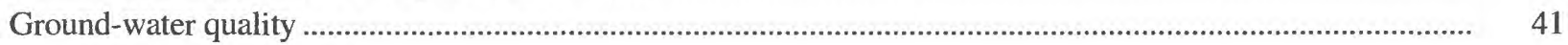

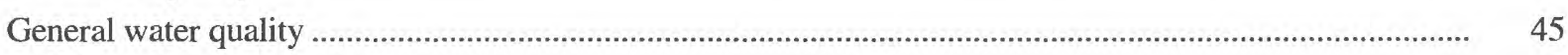

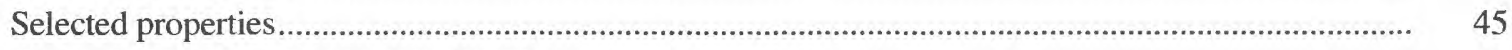

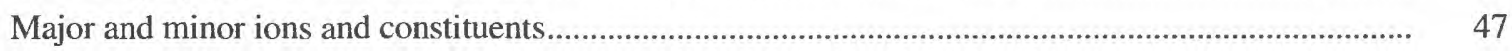

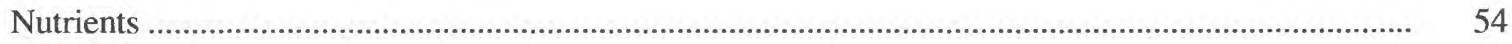

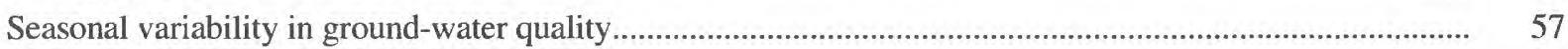

Ground-water quality related to land use …................................................................................... 57

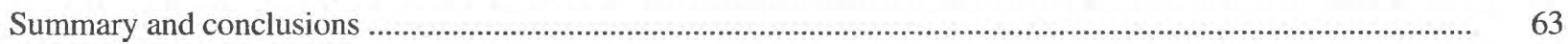

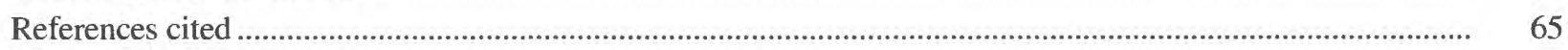

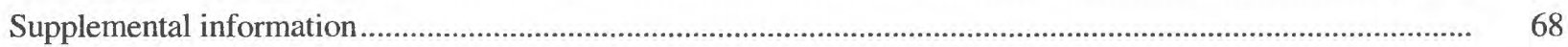

\section{Illustrations}

Figure 1-5. Map showing:

1. Location of study area, Leech Lake Indian Reservation, trace of hydrogeologic section, watershed divides, wells with hydrographs, and streamflow-measurement sites.

2. Locations of non-U.S. Geological Survey wells and study area............................................ 5

3. Locations of non-U.S. Geological Survey wells in the vicinity of Cass and

Leech Lakes

4. Locations of U.S. Geological Survey observation wells, test holes, and study area................ 8

5. Water-quality sampling locations in study area ................................................................ 10 


\section{Illustrations-continued}

6. Diagram showing test-hole and well-numbering system

7. Map showing Quaternary geology of the study area

8. Hydrogeologic section showing hydrogeologic units in the study area, Leech Lake Indian Reservation, Minnesota

9-19. Map showing:

9. Saturated thickness of the unconfined aquifer

10. Saturated thickness of the unconfined aquifer in the vicinity of Cass and Leech Lakes.

11. Transmissivity of the unconfined aquifer.

12. Theoretical maximum well yield of the unconfined aquifer

13. Thickness of the uppermost confining unit

14. Thickness of the uppermost confining unit in the vicinity of Cass and Leech Lakes

15. Altitude at the top of uppermost confined aquifer

16. Altitude at the top of uppermost confined aquifer in the vicinity of Cass and Leech Lakes.

17. Thickness of the uppermost confined aquifer

18. Transmissivity of the uppermost confined aquifer.

19. Theoretical maximum well yield of the uppermost confined aquifer

20. Hydrographs showing water levels in wells screened in the unconfined aquifer, 1988-91, Leech Lake Indian Reservation, Minnesota.

21. Hypothetical hydrograph showing method of estimating recharge during spring to the unconfined aquifer.

22. Hydrographs showing water levels in wells screened in the uppermost confined aquifer, 1990-91, Leech Lake Indian Reservation, Minnesota

23-25. Map showing:

23. Altitude of water table in the unconfined aquifer

24. Potentiometric surface of the uppermost confined aquifer

25. Potentiometric surface of the uppermost confined aquifer in the vicinity of Cass and Leech Lakes.

26. Hydrogeologic section showing isopotential lines and generalized direction of groundwater flow, Leech Lake Indian Reservation, Minnesota 


\section{Illustrations-continued}

27. Piper diagrams of chemical characteristics of water in the unconfined and uppermost

confined aquifers, Leech Lake Indian Reservation, Minnesota

28-31. Boxplots showing:

28. Concentrations of dissolved solids, specific conductance, hardness, and alkalinity in water from the unconfined and uppermost confined aquifers, Leech Lake Indian Reservation, Minnesota

29. Concentrations of dissolved calcium, dissolved sodium, dissolved potassium, and dissolved magnesium in water from the unconfined and uppermost confined aquifers, Leech Lake Indian Reservation, Minnesota

30. Concentrations of dissolved sulfate, dissolved chloride, dissolved nitrite plus nitrate nitrogen, and total phosphorus in water from the unconfined and uppermost confined aquifers, Leech Lake Indian Reservation, Minnesota .

31. Concentrations of dissolved organic carbon, dissolved boron, dissolved iron, and dissolved manganese in water from the unconfined and uppermost confined aquifers, Leech Lake Indian Reservation, Minnesota.

32. Diagram showing suitability of water from the unconfined and uppermost confined aquifers for irrigation in terms of sodium and salinity hazards, Leech Lake Indian Reservation, Minnesota

\section{Tables}

Table 1. Selected constituents and properties determined for sampled wells used to establish baseline conditions

2. Statistical summaries of water-quality data for wells screened in the unconfined and uppermost confined aquifers, Leech Lake Indian Reservation, Minnesota

3. U.S. Environmental Protection Agency recommended limits for selected constituents in ground water and number of wells sampled where water exceeds the limits, Leech Lake Indian Reservation, Minnesota.

4. Seasonal water-quality data for selected wells screened in the unconfined aquifer, Leech Lake Indian Reservation, Minnesota.

5. Water-quality data for selected wells sampled for minor elements screened in the unconfined aquifer, Leech Lake Indian Reservation, Minnesota

6. Water-quality data for selected wells sampled for herbicides screened in the unconfined aquifer, Leech Lake Indian Reservation, Minnesota

7. Constituents determined for selected wells sampled for U.S. Environmental Protection Agency priority pollutants

8. Selected data from commerical driller's logs of wells in the study area, Leech Lake Indian Reservation, Minnesota

9. Baseline water-quality data for wells screened in the unconfined aquifer, Leech Lake Indian Reservation, Minnesota. 


\section{Tables-continued}

10. Baseline water-quality data for wells screened in the uppermost confined aquifer, Leech Lake Indian Reservation, Minnesota.

\section{Conversion Factors, Vertical Datum, and Abbreviated Water Quality Units}

$\begin{array}{lc}\text { Multiply Inch-Pound Unit } & \text { By } \\ \text { inch (in.) } & 25.4 \\ \text { foot (ft) } & .3048 \\ \text { mile (mi) } & 1.609 \\ \text { foot per day (ft/d) } & .3048 \\ & .0003528 \\ \text { foot per mile (ft/mi) } & .1894 \\ \text { cubic foot per second }\left(\mathrm{ft}^{3} / \mathrm{s}\right) & 28.32 \\ \text { foot squared per day }\left(\mathrm{ft}^{2} / \mathrm{d}\right) & .09290 \\ \text { gallon per day }(\mathrm{gal} / \mathrm{d}) & .003785 \\ \text { gallon per minute }(\mathrm{gal} / \mathrm{min}) & .06309 \\ \text { million gallon per day }(\mathrm{Mgal} / \mathrm{d}) & .04381 \\ \text { square mile }\left(\mathrm{mi}^{2}\right) & 2.590\end{array}$

To Obtain Metric Unit

millimeter

meter

kilometer

meter per day centimeter per second

meter per kilometer

liter per second

meter squared per day

cubic meter per day

liter per second

cubic meter per second

square kilometer

Chemical concentrations are given in metric units. Chemical concentrations of substances in water are given in milligrams per liter $(\mathrm{mg} / \mathrm{L})$ or micrograms per liter $(\mu \mathrm{g} / \mathrm{L})$. Milligrams per liter is a unit expressing the concentration of chemical constituents in solution as weight (milligrams) of solute per unit volume (liter) of water. One thousand micrograms per liter is equivalent to one milligram per liter. For concentrations less than $7,000 \mathrm{mg} / \mathrm{L}$, the numerical value is the same as for concentrations in parts per million.

Sea level In this report "sea level" refers to the National Geodetic Vertical Datum of 1929-a geodetic datum derived from a general adjustment of the first-order level nets of both the United States and Canada, formerly called "Sea Level Datum of 1929". 


\section{Glossary}

The geologic and hydrologic terms pertinent to this report are defined as follows:

Aquifer - a formation, group of formations, or part of a formation that contains sufficient saturated permeable material to yield significant quantities of water to wells or springs.

Base flow-sustained streamflow, consists mainly of ground-water discharge to a stream.

Confined aquifer-an aquifer bounded above by confining units. An aquifer containing confined ground water. Synonymous with buried aquifer.

Confining unit - a body of material with low vertical permeability stratigraphically adjacent to one or more aquifers. Replaces the terms "aquiclude", "aquitard", and "aquifuge".

Dissolved - Pertains to the constituents in a representative water sample that pass through a $0.45 \mu \mathrm{m}$ (micrometer) membrane filter. The "dissolved" constituents are determined from subsamples of the filtrate. This convenient operational definition is used by Federal agencies that collect water data.

Drawdown - The vertical distance between the static (nonpumping) hydraulic head and hydraulic head caused by pumping.

Drift - A general term applied to all material (clay, sand, gravel, and boulders) transported and deposited by glacial ice or melt water.

Evapotranspiration-Water discharge to the atmosphere by evaporation from water surfaces and moist soil and by plant transpiration.

Ground water-That part of subsurface water that is in the saturated zone.

Head, hydraulic - The height, above a standard datum, of the surface of a column of water that can be supported by the static pressure at a given point.

Hydraulic conductivity - Capacity of porous material to transmit water under pressure. It is the rate of flow of water passing through a unit section of area under a unit hydraulic gradient.

Hydraulic gradient - The change in hydraulic head per unit distance of flow in a given direction. Synonymous with potentiometric gradient.

Outwash-Washed, sorted, and stratified drift deposited by water from melting ice.

Permeability - A measure of the relative ease with which a porous medium can transmit a fluid under a potential gradient.

Potentiometric surface - Surface that represents the static head of water in an aquifer; assuming no appreciable variation of head with depth in the aquifer, it is defined by the levels to which water will rise in tightly cased wells from a given point in an aquifer.

Saturated zone-Zone in which all voids are ideally filled with water. The water table is the upper limit of this zone. Water in the saturated zone is under pressure equal to or greater than atmospheric.

Specific capacity - Rate of discharge of water from a well divided by the drawdown of water level within the well.

Specific yield - The ratio of the volume of water that an aquifer material will yield by gravity drainage to the volume of the aquifer material. 


\section{Glossary-Continued}

Storage coefficient-The volume of water an aquifer releases from or takes into storage per unit surface area of the aquifer per unit change in head. In an unconfined aquifer, it is virtually equal to the specific yield.

Surficial aquifer-The saturated zone between the water table and the first underlying confining unit; synonymous with unconfined aquifer.

Till—Unsorted, unstratified drift deposited directly by glacial ice.

Transmissivity-The rate at which water of the prevailing kinematic viscosity is transmitted through a unit width of an aquifer under a unit hydraulic gradient.

Unconfined aquifer-An aquifer that has a water table; the saturated zone between the water table and the first underlying confining unit; synonymous with surficial aquifer.

Water table-That surface in an unconfined ground-water body at which the water pressure is atmospheric.

Generally, this is the upper potentiometric surface of the zone of saturation. 


\title{
Hydrogeology and Ground-Water Quality of Glacial-Drift Aquifers, Leech Lake Indian Reservation, North-Central Minnesota
}

\author{
By Richard J. Lindgren
}

\begin{abstract}
Among the duties of the water managers of the Leech Lake Indian Reservation in north-central Minnesota are the development and protection of the water resources of the Reservation. The U.S. Geological Survey, in cooperation with the Leech Lake Indian Reservation Business Committee, conducted a three and one half-year study (1988-91) of the ground-water resources of the Leech Lake Indian Reservation. The objectives of this study were to describe the availability and quality of ground water contained in glacial-drift aquifers underlying the Reservation.

Aquifers and confining units are present throughout the entire thickness of the glacial drift in the study area, which includes the Leech Lake Indian Reservation and adjacent parts of Beltrami, Hubbard, Itasca, and Cass Counties in north-central Minnesota, an area of approximately 2,145 square miles. An unconfined aquifer underlies most of the central and north-central parts of the study area. The saturated thickness of the aquifer ranges from 0 to about 105 feet. Horizontal hydraulic conductivity, estimated from 19 slug tests, ranges from 0.6 to 31 feet per day. The transmissivity of the aquifer ranges from 19 to more than 20,000 feet squared per day and is greatest in an area from west of Cass Lake to Lake Winnibigoshish. Theoretical maximum well yields range from less than 10 to about 2,000 gallons per minute. The unconfined and uppermost confined aquifers are physically and hydraulically separated by a fine-grained confining unit, consisting of till or lake deposits, that ranges in thickness from 3 to 254 feet.
\end{abstract}

The thickness of the uppermost confined aquifer ranges from 5 to about 53 feet. On the basis of specific-capacity data, the transmissivity of the aquifer ranges from less than 100 feet squared per day in the northeastern and southeastern parts of the study area to about 21,000 feet squared per day near Cass Lake. Theoretical maximum well yields range from less than 10 to about 2,600 gallons per minute.

Recharge to the ground-water system is predominantly from precipitation that infiltrates to the saturated zone. An analysis of four hydrographs for observation wells screened in the unconfined aquifer indicated spring recharge amounts during 1989 of 1-4 inches.

Discharge from the ground-water system occurs by leakage to streams, lakes, and wetlands, evapotranspiration, withdrawals by wells, and underflow to the southeast within the Mississippi River Valley. Streamflow measurements indicate that ground-water discharge to the Mississippi River is greater in the western part of the study area between Cass Lake and Lake Winnibigoshish than in the eastern part downstream from Lake Winnibigoshish.

The general regional direction of ground-water flow in the unconfined and uppermost confined aquifers is to the east and southeast. Ground-water flow is also toward the Mississippi River and the three large lakes in the study area, Lake Winnibigoshish and Cass and Leech Lakes.

Water moves through the ground-water system predominantly horizontally in the aquifers, whereas vertical components of flow are significant in confining units. Downward leakage of water occurs in highland areas where ground water flows downward from overlying till to the uppermost confined aquifer. Water moves vertically upward from deep to shallow aquifers in areas of regional discharge, the Mississippi River, Cass Lake, Lake Winnibigoshish, and Leech Lake.

Waters from both the unconfined and uppermost confined aquifers generally are suitable for domestic consumption, crop irrigation, and most other uses. Concentrations of iron and manganese in water from both aquifers frequently exceed levels that may impart an undesirable taste or odor to water.

Calcium and bicarbonate are the predominant ions in water from both the unconfined and uppermost confined aquifers. Water from both the unconfined and uppermost confined aquifers is hard to very hard, averaging 187 and 247 milligrams per liter as calcium carbonate, respectively. 
Differences in the mean concentrations of constituents in waters from the unconfined and uppermost confined aquifers vary. The mean concentrations of chloride, manganese, dissolved organic carbon, sulfate, and dissolved iron were greater for water from the unconfined aquifer than for water from the uppermost confined aquifer. Conversely, the mean concentrations of calcium, potassium, silica, sodium, fluoride, and boron were greater for water from the uppermost confined aquifer than for water from the unconfined aquifer. These higher concentrations of naturally occurring constituents in waters from the uppermost confined aquifer may occur because of the longer flow paths and longer residence times of water in the uppermost confined aquifer as compared to the unconfined aquifer.

Nutrients include nitrogen and phosphorus species. The mean concentrations of dissolved nitrogen $\left(\mathrm{NO}_{2}+\mathrm{NO}_{3}\right.$, dissolved) and total phosphorus were about 5 and 1.5 times greater for water from the unconfined aquifer than for water from the uppermost confined aquifer, respectively. None of the water samples had concentrations of dissolved nitrogen greater than the maximum contaminant level established by the U.S. Environmental Protection Agency (10 milligrams per liter) and only one water sample had a concentration greater than 3 milligrams per liter.

Water collected from wells completed in the unconfined aquifer in residential and recreational land-use areas had concentrations of arsenic, cadmium, chromium, copper, lead, mercury, and cyanide equal to or less than 6 micrograms per liter. Concentrations of organic-acid herbicides in water from three wells screened in the unconfined aquifer in managed-forest land-use areas were all below detection levels. Concentrations of U.S. Environmental Protection Agency priority pollutants in water from three wells screened in the unconfined aquifer and from one well screened in the uppermost confined aquifer were also all below detection levels.

\section{Introduction}

Studies of water resources on Indian reservations are underway throughout the United States. The impetus for these studies was a 1978 Federal mandate to the Bureau of Indian Affairs to review water-rights claims in reservations throughout the United States. Current information about the water resources of the reservations is generally insufficient to conduct this review of water-rights claims. The Bureau of Indian Affairs mandate sets forth a plan to gather, organize, and present information about the water resources of Indian reservations through a series of appraisal-level studies. The objectives of these studies include an inventory of the water resources and assessment of water use for each of the reservations. The reports produced from these studies are sources of information for tribal officials who have water-resource management responsibilities.

The U.S. Geological Survey, in cooperation with the Leech Lake Indian Reservation Business Committee, conducted a three and one half-year study (1988-91) of the ground-water resources of the Leech Lake Indian Reservation. The study was designed to provide the data and analyses needed to define the availability and quality of ground-water resources on the Reservation. Only ground water was studied because the Leech Lake Indian Reservation has a program to evaluate surfacewater resources of the Reservation. Residents of this Reservation depend on ground water as their principal source of water for drinking and household uses. Reservation water managers are interested in future development of these resources and protecting the quality of ground water.

\section{Purpose and Scope}

This report describes the presence, availability, and quality of ground-water resources of the Leech Lake Indian Reservation (hereinafter referred to as the Reservation) and adjacent areas. The report objectives are to (1) describe the availability of water from unconfined and confined glacial-drift aquifers, (2) define baseline quality of ground water for use in future assessments of long-term trends, (3) describe seasonal changes in water quality, and (4) relate ground-water quality to land-use practices. The study area (fig. 1) includes areas adjacent to the Reservation necessary to interpret the available information and define the ground-water system within the boundaries of the Reservation. The unconfined and confined glacial-drift aquifers will hereinafter be referred to as the unconfined and confined aquifers, respectively.

The unconfined and uppermost confined aquifers are the only aquifers considered in detail in this report. Other aquifers exist below these aquifers but data are insufficient to define their extent or hydraulic characteristics. 


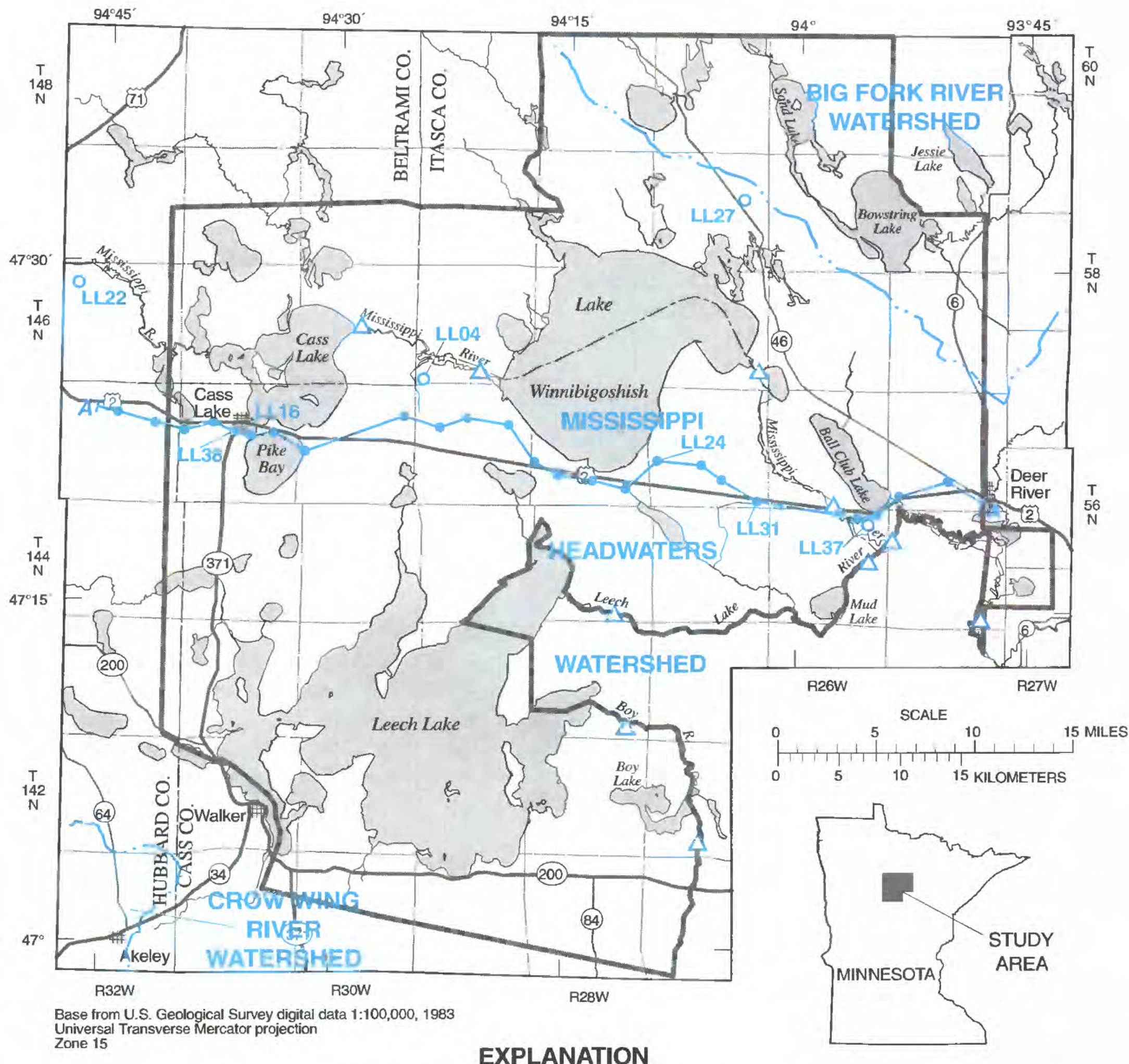

Leech Lake Indian Reservation boundary

$A \longmapsto$ Trace of hydrogeologic section

Watershed divide

$\triangle \quad$ Streamflow measurement site

- Wells on hydrogeologic section--Label refers to wells with hydrographs shown on figures 20 and 22

oLL27 Well not on hydrogeologic section--Label refers to wells with hydrographs shown on figures 20 and 22

Figure 1. Location of study area, Leech Lake Indian Reservation, trace of hydrogeologic section, watershed divides, wells with hydrographs and streamflow-measurement sites. 


\section{Location and Description of Study Area}

The study area covers approximately $2,145 \mathrm{mi}^{2}$ in north-central Minnesota and includes parts of Beltrami, Hubbard, Itasca, and Cass Counties (fig. 1).

Information from previous studies (Oakes and Bidwell, 1968; Lindholm and others, 1976) indicates that the surficial geology of the Reservation consists of glacial till, glacial outwash and scattered peatlands. Most ground water is obtained from unconfined and confined sand and gravel aquifers in glacial drift. The drift contains confined sand and gravel aquifers that may be as much as $\mathbf{5 0} \mathrm{ft}$ thick (Oakes and Bidwell, 1968). The thickness of the drift ranges from 50 to $500 \mathrm{ft}$ and overlies crystalline bedrock, which has not been developed for water supply (Oakes and Bidwell, 1968).

Most of the study area lies within the Mississippi headwaters watershed. It is drained by the Mississippi River in the central part and the Boy River in the southeastern part. The northeastern part of the study area lies within the Big Fork River watershed. The extreme southwestern part of the study area lies within the Crow Wing River watershed. Annual precipitation ranges from 23 to 25.5 in. (Baker and Kuehnast, 1978), with most occurring as rain from May to September. Potential annual evapotranspiration is about 22 in. (calculated using the Thornthwaite method) and annual runoff is about 7 to 8 in. (Baker and others, 1979, p. 6 and 8).

Land use in the study area is a mixture of several types. The predominant land uses are forestry and recreation. Forested areas consist of second or thirdgrowth stands of trees that are primarily harvested for paper pulp and wood products. Several large lakes, including Leech and Cass Lakes and Lake Winnibigoshish and numerous smaller lakes are present in the area. Residential and urban areas are primarily concentrated at and around the towns of Cass Lake (population 923 in 1990), Walker (950), Deer River (838), Bena (147), and Ball Club (60). Resort areas are prevalent along the shores of Lake Winnibigoshish and Cass and Leech Lakes. Commercial areas are not extensive and primarily exist as localized areas of light industry, transportation, and commerce.

\section{Previous Investigations}

A number of previous investigations have described the general glacial history of Minnesota, including Wright and Ruhe (1965) and Wright (1972). Wright and others (1973) and Wright (1973) describe the glacial history and glacial geology of the Superior and Des Moines lobes of Wisconsin age in the area.
A hydrologic atlas by Oakes and Bidwell (1968) summarizes the climate, hydrogeology, surface-water resources, and water quality of the Mississippi River headwaters watershed, which includes most of the study area. A hydrologic atlas by Lindholm and others (1976) describes the water resources of the Big Fork River watershed, which includes the northeastern part of the study area. A hydrologic atlas by Lindholm and others (1972) describes the water resources of the Crow Wing River watershed, which includes the extreme southwestern corner of the study area.

\section{Methods of Investigation}

Field work for this study was conducted during 198891. Hydrogeologic maps were prepared using reported data from wells and test holes obtained from files of the Minnesota Geological Survey and the U.S. Geological Survey, and geologic logs from 54 test holes drilled for this study (figs. 2, 3, and 4). The location of wells having driller's logs was confirmed by locating the wells in the field or by confirming the location of wells from county plat books. Location, geologic, and hydrologic information from the logs were entered into a computer data base. Data points were assigned a Minnesota Geological Survey well number, latitude, and longitude. The computer data base was used to prepare maps showing the thickness, extent, and hydrologic properties of the unconfined and uppermost confined aquifers and of the uppermost confining unit. Well logs and test-hole logs used to prepare all maps are available from the U.S. Geological Survey, Minnesota District.

The wells and test holes are not uniformly distributed over the study area. Much of the data from domesticwell logs is concentrated in small areas in and near towns and in resort areas along the shores of Lake Winnibigoshish, and Cass and Leech Lakes. The density of domestic-well logs is particularly high in the west-central part of the study area near the towns of Cass Lake and Walker and the western shorelines of Cass and Leech Lakes. Figures with maps showing subregions of the study area are used in this report to more clearly present information in the west-central part of the study area where the wells and test holes are concentrated (fig. 3). The northern subregion is an area of approximately $170 \mathrm{mi}^{2}$, and includes Cass Lake and Pike Bay. The southern subregion is an area of approximately $170 \mathrm{mi}^{2}$, and includes Steamboat Bay.

Nineteen test holes (fig. 4) were completed as observation wells to determine spatial and temporal changes in water levels in the unconfined aquifer and to collect water samples for chemical analysis. Data from these wells, coupled with water-level data from well 


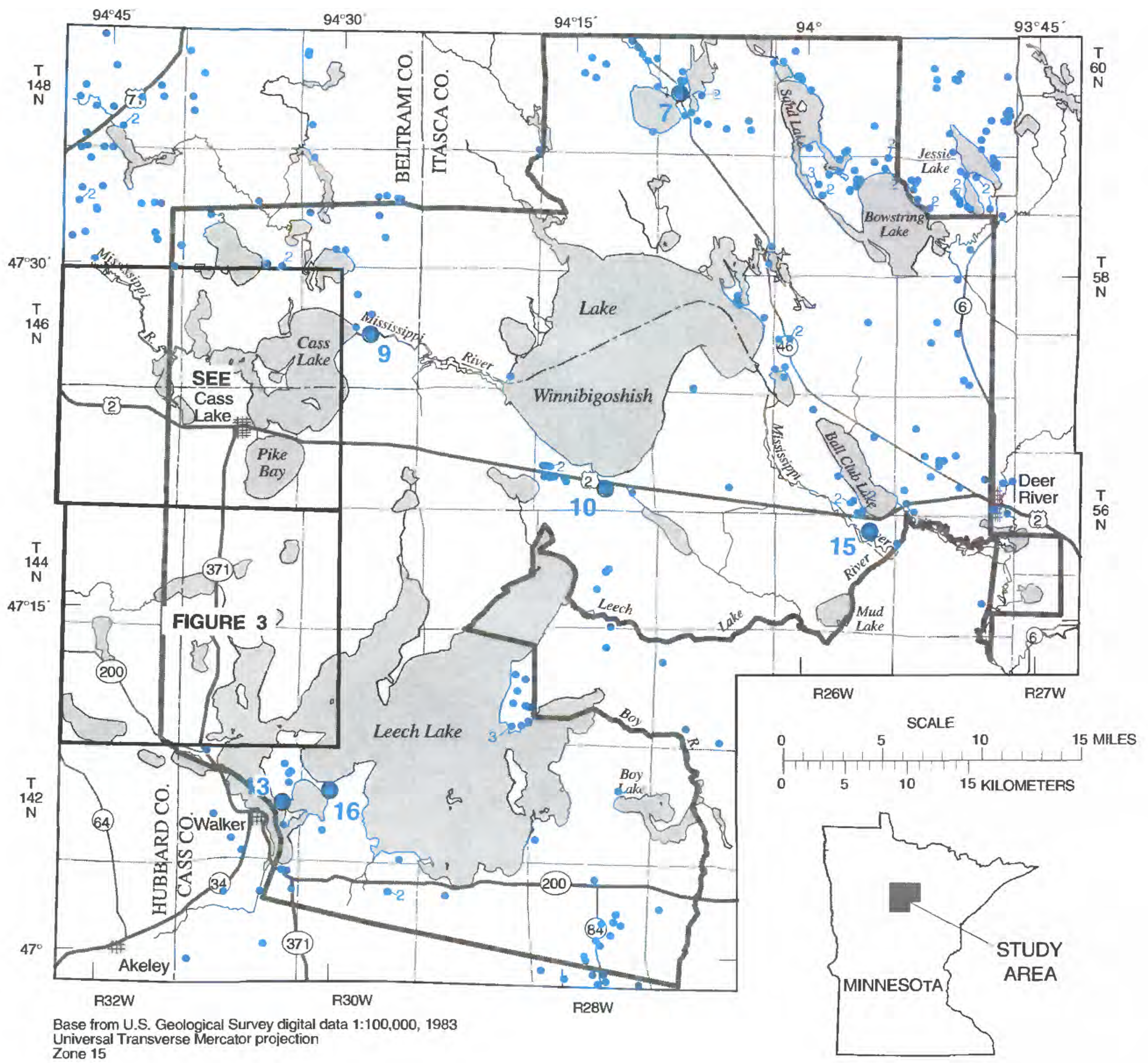

EXPLANATION

Leech Lake Indian Reservation boundary

$0^{7}$ Cluster of closely-spaced well sites--Number indicates number of wells in cluster

- Well site--Number indicates number of wells at site

Figure 2. Locations of non-U.S. Geological Survey wells and study area. 


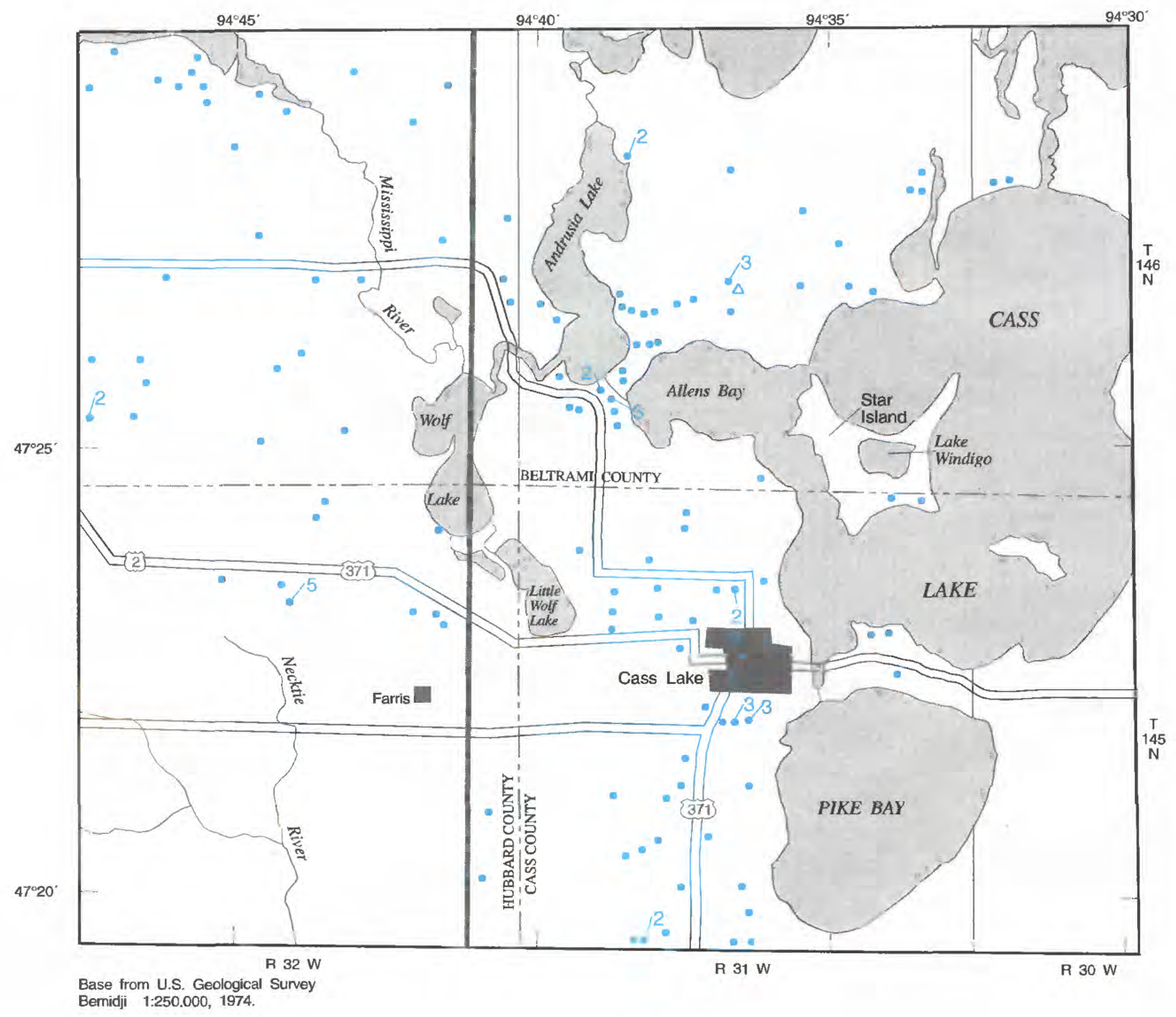

EXPLANATION

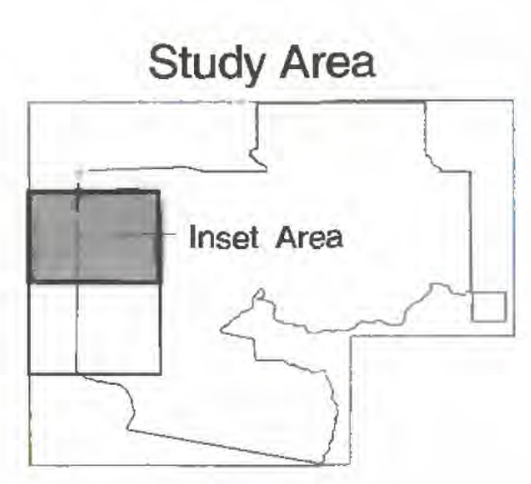

Leech Lake Indian Reservation boundary

- Well site--Number indicates number of wells at site

4. Test hole

Figure 3. Locations of non-U.S. Geological Survey 

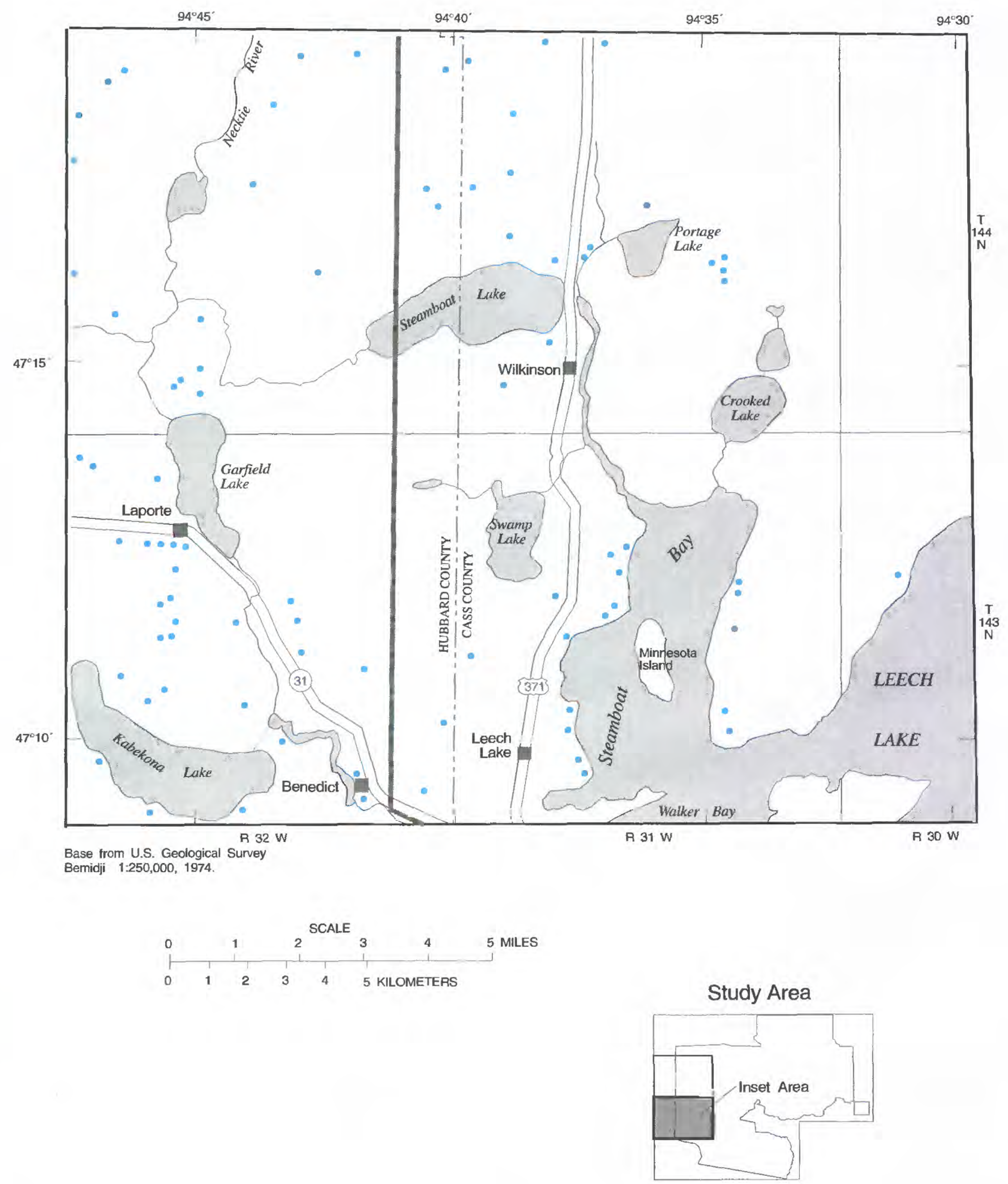

wells in the vicinity of Cass and Leech Lakes. 


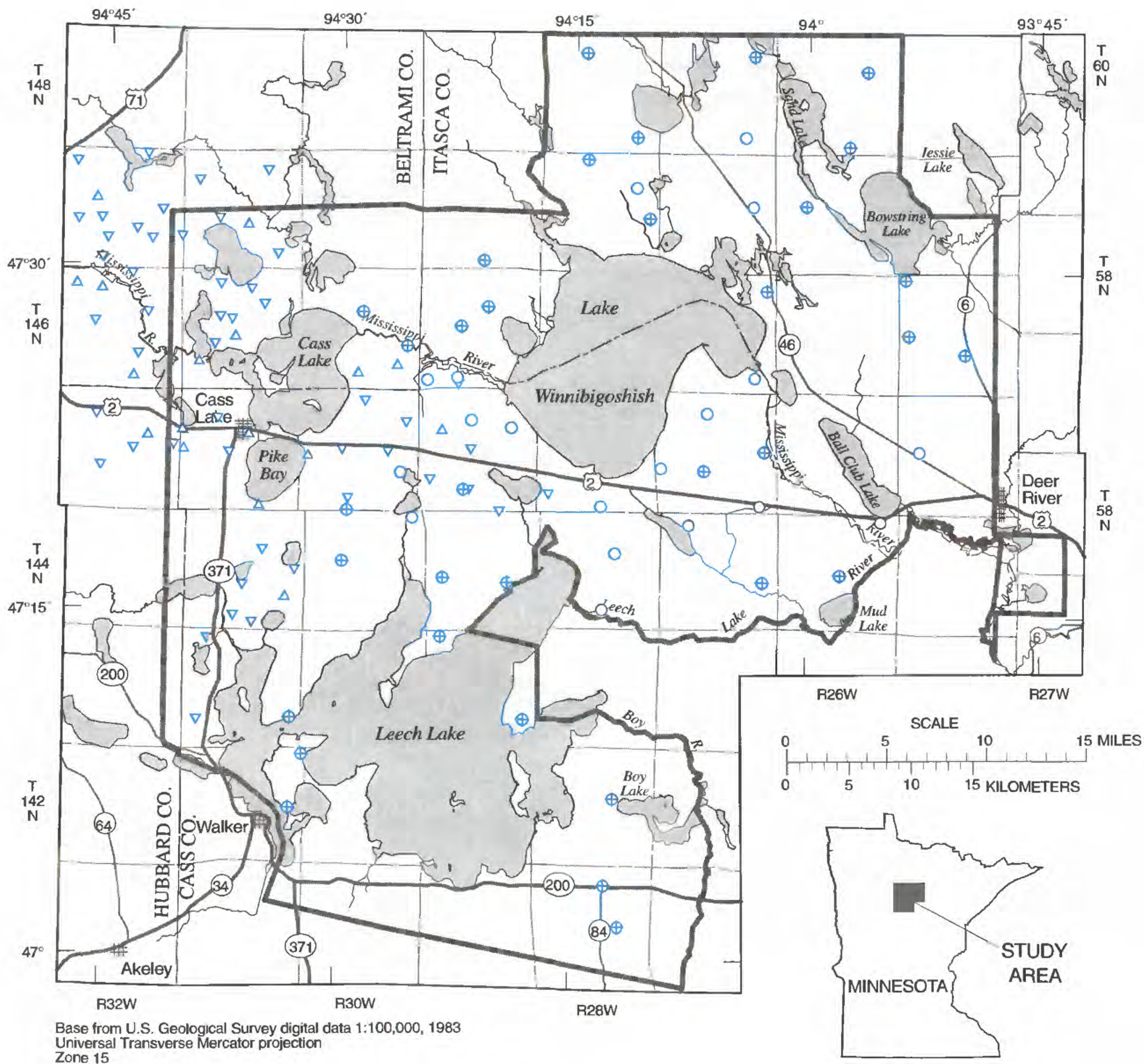

EXPLANATION

Leech Lake Indian Reservation boundary

$\triangle \quad$ Observation well installed for previous study

$\nabla \quad$ Test hole drilled for previous study

- Observation well installed in test hole drilled for this study

$\oplus \quad$ Test hole drilled for this study

Figure 4. Locations of U.S. Geological Survey observation wells, test holes, and study area. 
logs, were used to produce potentiometric-surface maps of the unconfined and uppermost confined aquifers.

Horizontal hydraulic conductivities for the unconfined aquifer were estimated from slug tests conducted at 19 observation wells. Slug tests were conducted at 9 wells installed for a previous study and at 10 wells installed for this study. The slug tests were conducted and the results analyzed using methods described by Bouwer and Rice (1976) and Bouwer (1989).

Transmissivity was estimated from specific-capacity information available from well logs for 7 locations in the unconfined aquifer and for $\mathbf{5 7}$ locations in the uppermost confined aquifer. The specific capacity of a well is the rate of discharge of water from the well divided by the drawdown of water level within the well. The value of transmissivity estimated from specificcapacity information was assumed to apply only to the screened zone of the aquifer. To apply this value to the entire aquifer, the transmissivity is divided by the length of the well screen (to determine the hydraulic conductivity per unit of length), and the result is multiplied by the entire thickness of the aquifer (Heath, 1983, p. 60-61).

The theoretical maximum yields of wells in the unconfined and uppermost confined aquifers were estimated using a chart developed by Meyer (1963) which relates well diameter, specific capacity, the transmissivity, and storage coefficient to well yield. The relation shows that for confined aquifers (storage coefficients less than about 0.005 ), large differences in storage coefficients correspond to relatively small differences in specific capacity; therefore, inaccurate estimation of storage coefficient is not a serious limiting factor in estimating theoretical well yields. The chart developed by Meyer assumes that the wells are 100 percent efficient, the effective diameter of the well is approximately the same as the physical diameter of the well, the well is screened through the entire thickness of the aquifer, and the well is pumped continuously for 24 hours (confined aquifer) or until steady-state conditions occurred (unconfined aquifer). The chart also assumes, for unconfined aquifers, that the water-level drawdown is not a substantial fraction of the original saturated thickness.

The theoretical maximum well yield at a site with specific-capacity data can be estimated by multiplying the specific capacity by the available drawdown. In computing the theoretical maximum yields, available drawdown was assumed to be (1) depth to water minus depth to screen for the unconfined aquifer, and (2) depth to water minus depth to the top of the aquifer for the uppermost confined aquifer. The theoretical maximum well yield for the unconfined aquifer was computed by (1) determining the specific capacity at a site using the chart by Meyer (1963), and (2) multiplying the specific capacity by the available drawdown. The chart developed by Meyer shows that for transmissivities of approximately 270 to $13,000 \mathrm{ft}^{2} / \mathrm{d}$ the ratio of transmissivity $\left(\mathrm{ft}^{2} / \mathrm{d}\right.$ ) to specific capacity ( $\mathrm{gal} / \mathrm{min}$ per foot of drawdown) is about 320 to 1 for confined aquifers. The ratio is larger for greater transmissivities. Therefore, for confined aquifers with transmissivities of 270 to $13,000 \mathrm{ft}^{2} / \mathrm{d}$, the specific capacity can be approximated by dividing the transmissivity by 320 .

Water samples to determine baseline water quality were collected from 48 wells during July and August 1989 and during August 1990. Thirty one of the wells were screened in the unconfined aquifer and 17 wells were screened in the uppermost confined aquifer (fig. 5). All selected wells were sampled for an identical group of major common constituents (table 1). Additional samples were collected from 6 wells screened in the unconfined aquifer during September 1989 and during February and May 1990 to determine seasonal changes in water quality. Water samples were collected from 10 wells screened in the unconfined aquifer during August 1989 to assess the quality of the ground water in relation to land use. Land-use types are forestry, recreational, and residential. Seven wells were sampled for minor elements and 3 wells were sampled for herbicides. Water samples were collected from 4 wells during March and May 1991 to check for the presence of contaminants specified by the U.S. Environmental Protection Agency (1986) as priority pollutants; three of these wells were screened in the unconfined aquifer and one well was screened in the uppermost confined aquifer. The sampling procedures used generally were the same as those recommended by Have and Tornes (M.R. Have and L.H. Tornes, U.S. Geological Survey, Minnesota, written commun., 1985).

All samples were analyzed at the U.S. Geological Survey Laboratory in Arvada, Colorado. Inorganic constituents were analyzed by procedures outlined in Fishman and Friedman (1985). Volatile organics and pesticides were analyzed according to procedures in Wershaw and others (1983). 


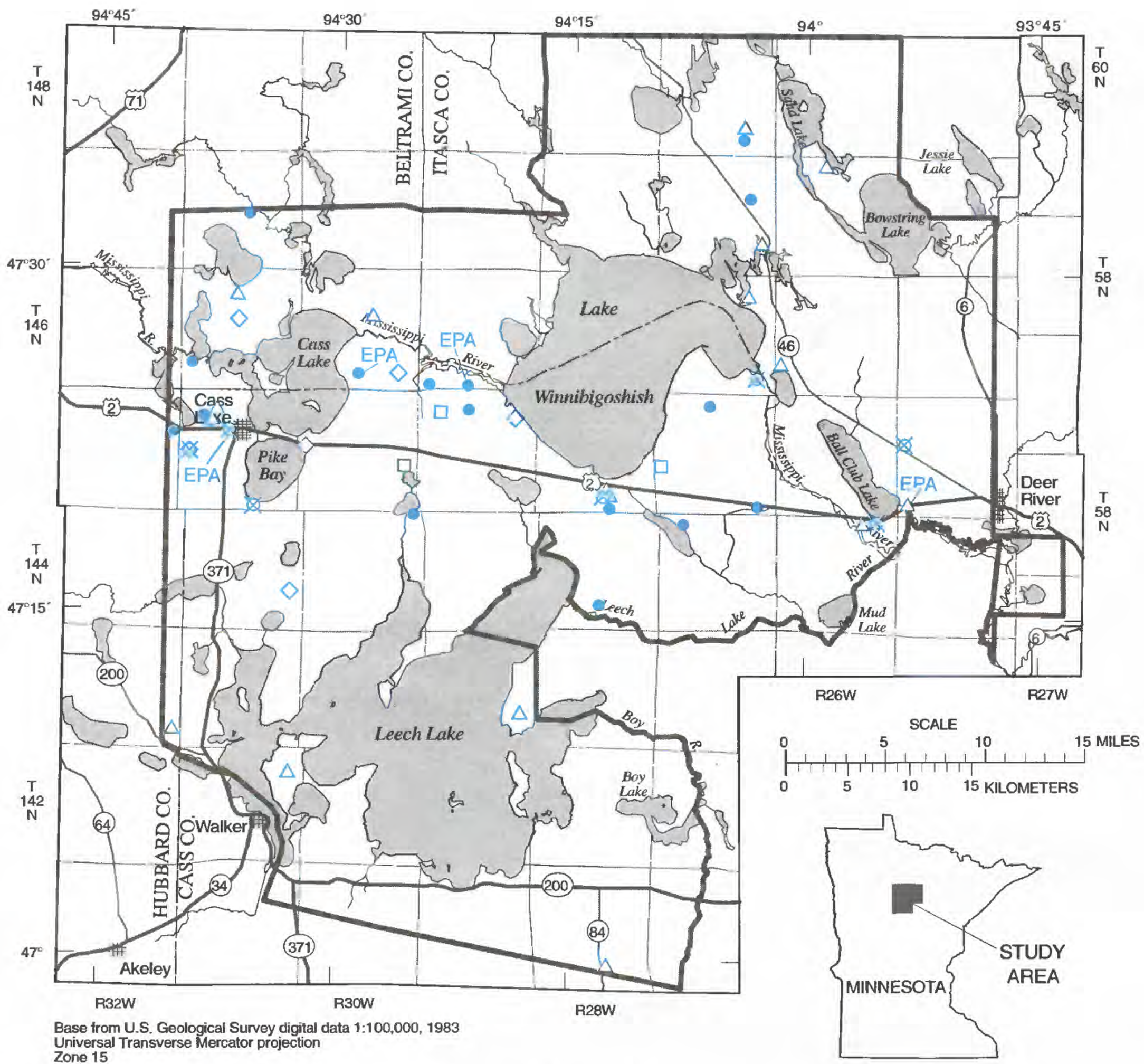

EXPLANATION

Leech Lake Indian Reservation boundary

- Well screened in unconfined aquifer--EPA indicates well also was sampled for USEPA priority pollutants

$\triangle \quad$ Well screened in uppermost confined aquifer--EPA indicates well also was sampled for USEPA priority pollutants

$\diamond \quad$ Well sampled seasonally--Screened in unconfined aquifer

Well sampled for minor elements--Screened in unconfined aquifer.

EPA indicates well also was sampled for USEPA priority pollutants

Well sampled for herbicides--Screened in unconfined aquifer

Figure 5. Water-quality sampling locations in study area. 
Table 1.--Selected constituents and properties determined for sampled wells used to establish baseline conditions

[Reporting level is the lowest measured concentration of a constituent that may be reliably reported. The reporting level is set somewhat higher than the detection level. $\mathrm{mg} / \mathrm{L}$, milligrams per liter; $\mu \mathrm{g} / \mathrm{L}$, micrograms per liter; $\mu \mathrm{S} / \mathrm{cm}$, microsiemens per centimeter at 25 degrees Celsius; field, value determined at the sampling site; lab, value determined in a laboratory; --, not determined]

\begin{tabular}{|c|c|}
\hline Property or constituent & Reporting level \\
\hline \multicolumn{2}{|l|}{ Miscellaneous constituents and properties } \\
\hline Temperature (degrees Celsius) & -- \\
\hline Specific conductance, field $(\mu \mathrm{S} / \mathrm{cm})$ & - \\
\hline $\mathrm{pH}$, field (standard units) & - \\
\hline Alkalinity, field, (mg/L as $\left.\mathrm{CaCO}_{3}\right)$ & 1 \\
\hline Organic carbon, dissolved (mg/L as $\mathrm{C}$ ) & .1 \\
\hline Specific conductance, lab $(\mu \mathrm{S} / \mathrm{cm})$ & - \\
\hline $\mathrm{pH}$, lab (standard units) & - \\
\hline Alkalinity, lab (mg/L as $\left.\mathrm{CaCO}_{3}\right)$ & .1 \\
\hline Dissolved solids, calculated, sum of constituents ( $\mathrm{mg} / \mathrm{L}$ ) & 1 \\
\hline Hardness $\left(\mathrm{mg} / \mathrm{L}\right.$ as $\mathrm{CaCO}_{3}$ ) & - \\
\hline \multicolumn{2}{|l|}{ Nutrients } \\
\hline Nitrogen, nitrite plus nitrate ( $\mathrm{mg} / \mathrm{L}$ as $\mathrm{N}$ ) & .10 \\
\hline Nitrogen, ammonia, dissolved (mg/L as $\mathrm{N}$ ) & .01 \\
\hline Total phosphorus, (mg/L as $\mathrm{P}$ ) & .01 \\
\hline Phosphorus, dissolved orthophosphate (mg/L as $\mathrm{P}$ ) & .01 \\
\hline \multicolumn{2}{|l|}{ Major inorganic constituents } \\
\hline Calcium, dissolved ( $\mathrm{mg} / \mathrm{L}$ as $\mathrm{Ca})$ & .1 \\
\hline Magnesium, dissolved (mg/L as $\mathrm{Mg}$ ) & .1 \\
\hline Sodium, dissolved (mg/L as $\mathrm{Na}$ ) & .1 \\
\hline Potassium, dissolved (mg/L as $\mathrm{K}$ ) & .1 \\
\hline Sulfate, dissolved (mg/L as $\left.\mathrm{SO}_{4}\right)$ & .2 \\
\hline Chloride, dissolved (mg/L as $\mathrm{Cl}$ ) & .1 \\
\hline \multicolumn{2}{|l|}{ Minor inorganic constituents } \\
\hline Fluoride, dissolved (mg/L as F) & .1 \\
\hline Silica, dissolved ( $\mathrm{mg} / \mathrm{L}$ as $\left.\mathrm{SiO}_{4}\right)$ & .1 \\
\hline Boron, dissolved ( $\mu \mathrm{g} / \mathrm{L}$ as $\mathrm{B})$ & 10 \\
\hline Iron, dissolved ( $\mu \mathrm{g} / \mathrm{L}$ as Fe) & 1 \\
\hline Manganese, dissolved ( $\mu \mathrm{g} / \mathrm{L}$ as $\mathrm{Mn})$ & 1 \\
\hline
\end{tabular}




\section{Test-Hole and Well-Numbering System}

Two systems of numbering wells and test holes were used for this study. The first system used was the Minnesota Geological Survey unique-well number system that associates a well with a latitude and longitude. The second system of numbering wells and test holes is based on the U.S. Bureau of Land Management's system of land subdivision (township, range, and section). Figure 6 illustrates the numbering system. The first numeral of a test hole or well number indicates the township, the second the range, and the third the section in which the well or test hole is located. Uppercase letters after the section number indicate the location within the section; the first letter denotes the 160-acre tract, the second the 40 acre tract, the third the 10 acre tract, and the fourth the 2.5 acre tract. The letters A, B, C, and D are assigned in a counterclockwise direction, beginning in the northeast corner in each tract. Within a given 2.5 acre tract successive well numbers beginning with 01 are added as suffixes. The number of uppercase letters indicates the accuracy of the location number. For example, the number 145.28.07CCBA01 indicates the first test hole or well located in the NE1/4, NW1/4, SW1/4, SW1/4, Sec. 7, T.145 N., R.28 W.

\section{Acknowledgments}

The author is grateful to land owners who permitted the drilling of test holes and the installation of observation wells, to well owners who permitted sampling of their wells and measurement of water levels, and to employees of the Reservation who assisted in the well-log inventory.

\section{Hydrogeology}

Precambrian crystalline rocks directly underlie glacial drift throughout the study area. The glacial drift includes aquifers, composed of sand and gravel, and confining units, composed of clay and till. Groundwater flow through the drift is controlled by recharge to and discharge from the aquifers and the hydraulic properties of the aquifers and confining units.

\section{Bedrock}

Igneous and metamorphic rocks, primarily granite, gneiss, and schist, constitute the Precambrian rocks whose character and areal distribution has been inferred from gravity and magnetic data (Sims, 1970). These crystalline rocks typically have low porosities and low permeability, with water generally present only in fractures and in weathered zones near the upper surfaces of the formations. These rocks can be productive aquifers where fracturing or weathering have increased hydraulic conductivity. Bedrock aquifers have not been developed for water supplies within the study area. The bedrock surface is irregular due to preglacial erosion by streams and erosion from glacial ice and meltwater during the Wisconsin and prior glaciations.

\section{Glacial Drift}

At least three major ice lobes of late-Wisconsin age advanced over the study area (Wright, 1972). The Des Moines lobe, including the St. Louis sublobe, advanced over the study area from the northwest. The Wadena lobe advanced from the north-northwest. The Rainy lobe, including the Brainerd sublobe, advanced from the north-northeast. These ice lobes advanced and retreated separately as ice was preferentially directed by less resistant bedrock (Wright, 1972; Wright and Ruhe, 1965). The Itasca moraine complex, associated with Wadena lobe deposition, comprises the highlands in the southwestern portion of the study area. Till deposited by the Wadena lobe is noncalcareous, brown, and siltyclay in texture, but tends to contain abundant sand in the area of the Itasca moraine. Contemporaneous deposits of the Brainerd sublobe are present in the eastern and southeastern parts of the study area. Ground and end moraines associated with the Brainerd sublobe are overlain by deposits of the St. Louis sublobe (of the Des Moines lobe) in the northeastern part of the study area. Till associated with the St. Louis sublobe of the Des Moines lobe generally is yellowish-brown, calcareous, and silty to sandy in texture. The ground and stagnation moraines associated with the St. Louis sublobe are aproned by outwash sands in the central part of the study area.

Topography in areas where till is exposed at the land surface (moraines) generally is rolling and irregular. The land surface generally is flat to gently rolling in areas of surficial outwash (sand plains).

Quaternary glacial deposits or Holocene peat deposits cover the entire study area. These deposits consist primarily of till, outwash, and glacial-lake deposits. Glacial drift, ranging in thickness from 50 to $500 \mathrm{ft}$, was deposited at the base and edges of successive advances, stagnations, and retreats of glaciers. According to Hobbs and Goebel (1982), glacial drift in the study area includes morainal deposits and outwash. Ground moraine was deposited at the base of glaciers and is associated with glacial advances. End moraines (linear ridges) were deposited at the margins of the glaciers and are associated with active (flowing) ice margins. Moraines contain poorly sorted mixtures of materials ranging in size from clay to boulders with some discontinuous sand deposits. Outwash is sorted and deposited by meltwater beyond the front edge of the glacier, frequently resulting in extensive sand and gravel 


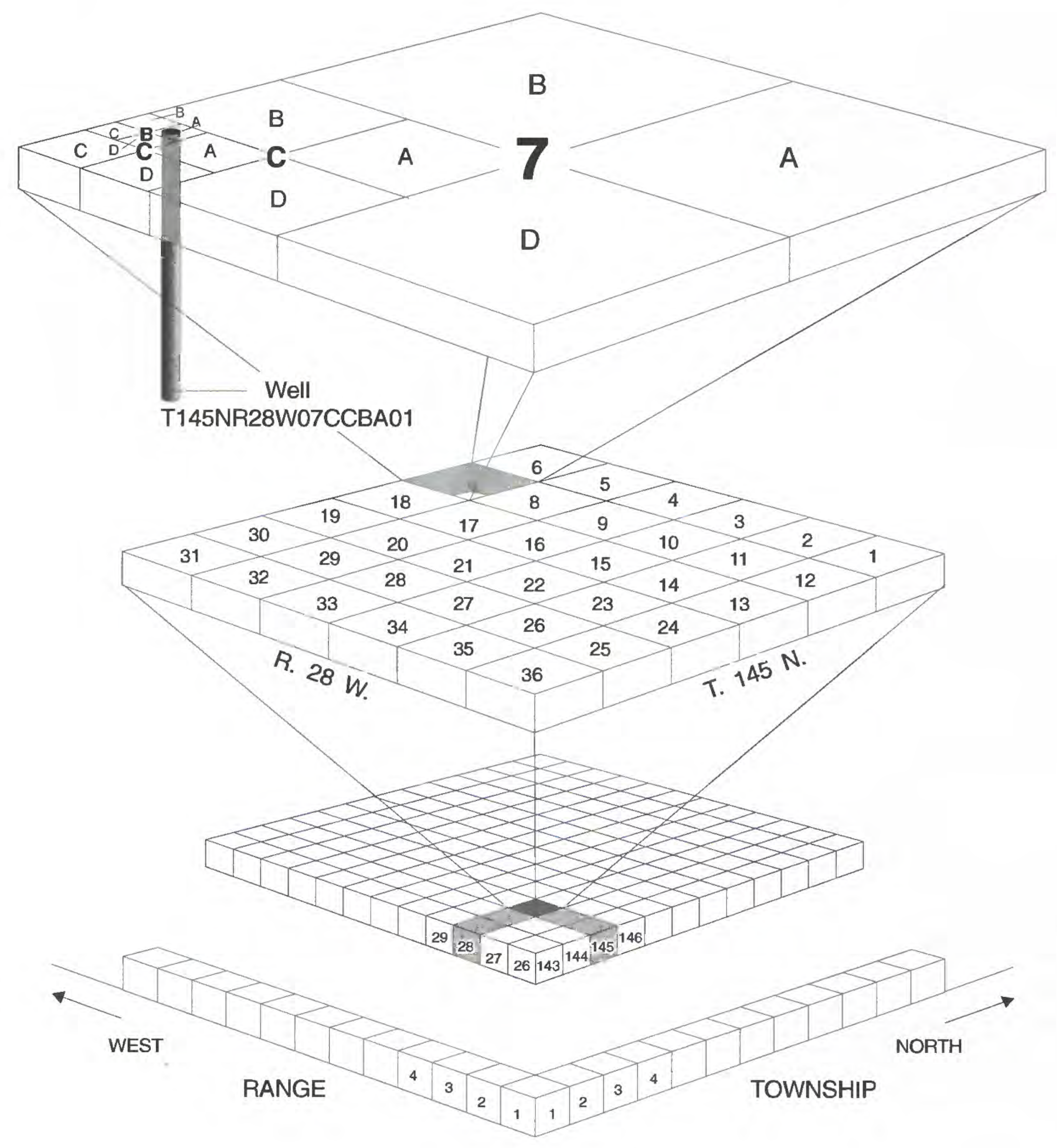

Figure 6. Test-hole and well-numbering system. 
deposits (sand plains). Some sand and gravel deposits were covered by till during subsequent glacial advances. These buried sand and gravel deposits are present throughout the study area. Glacial-lake deposits underlying the study area include peat; silt, sand, and clay; and modified till. The surficial (Quaternary) geology of the study area (fig. 7) was mapped by Oakes and Bidwell (1968), Lindholm and others (1972), and Lindholm and others (1976).

\section{Hydrogeologic units}

Aquifers and confining units are present throughout the entire thickness of the glacial drift in the study area. Because detailed data related to deeper hydrogeologic units (below the uppermost confined aquifer) are not available, these units are not considered in detail in this report. The uppermost confined aquifers and confining units identified from well logs were assumed to be continuous and to represent unified hydrogeologic units throughout the study area; however, data are scant, and the degree of physical and hydraulic continuity between these units is not known. Three hydrogeologic units were defined for the purpose of this study and are discussed in detail in this report: (1) unconfined aquifer, (2) uppermost confining unit, and (3) uppermost confined aquifer (fig. 8).

No well logs penetrate the uppermost confined aquifer along much of the western part of the cross section shown in figure 8 . The aquifer is inferred to be present along this part of the cross section, but is not necessarily present at the depths below land surface shown on the cross section. The uppermost confined aquifer is probably present, but at a depth above or below that shown on the cross section. Also, the uppermost confined aquifer in the western part of the cross section is shown as being physically continuous, but is probably physically discontinuous.

Unconfined and confined aquifers have hydrologically differing characteristics. Unconfined aquifers have an unsaturated zone above the water table. They tend to be highly productive in yielding water to wells. Unconfined aquifers can be rapidly recharged by infiltration from precipitation and tend to be susceptible to contamination from activities at land surface. Confined aquifers are fully saturated (hydraulic head is above the top of the aquifer) and are isolated from land surface by one or more confining units. Wells screened in confined aquifers tend to have lower specific capacities than wells screened in unconfined aquifers. Confined aquifers are recharged by leakage through overlying or underlying confining units, and therefore are comparatively well protected from contamination by activities that occur at land surface. They also can have a recharge area exposed at land surface.

\section{Unconfined aquifer}

The unconfined aquifer, which consists of glacial outwash and lake sediments, underlies most of the central and north-central parts of the study area (fig. 9). A north-south trending part of the aquifer, with large saturated thicknesses, extends from Pike Bay (Cass Lake) to Steamboat Bay (Leech Lake) (fig. 10). Several less extensive and isolated unconfined aquifers are present outside the boundaries of the main outwash deposit. The total area underlain by the unconfined aquifers is approximately $655 \mathrm{mi}^{2}$, with the main outwash deposit underlying approximately $560 \mathrm{mi}^{2}$. The unconfined aquifer generally consists of sand and fine gravel in the western part of the study area and fine to medium sand in the eastern part.

The top of the saturated portion of the unconfined aquifer is the water table and the base of the aquifer is the top of the uppermost confining unit. Depth to the water table below land surface ranges from 0 to about $60 \mathrm{ft}$. Depth to the water table is shallowest in the western and central parts of the study area where large surface-water bodies are present. The saturated thickness of the unconfined aquifer ranges from 0 to about $105 \mathrm{ft}$. Figures 9 and 10 show the saturated thickness of the unconfined aquifer. The greatest saturated thicknesses occur in the north-south trending part of the aquifer between Pike Bay and Steamboat Bay. For most of the rest of the aquifer's area, aquifer thickness ranges from about 15 to $30 \mathrm{ft}$, exceeding $20 \mathrm{ft}$ in an area of about $210 \mathrm{mi}^{2}$. In some areas outside the mapped extent of the aquifer, sand is present at the land surface but is unsaturated.

Except in the Cass Lake area, the unconfined aquifer is not used extensively as a source of water. Based on published values of horizontal hydraulic conductivity for similar deposits of sand and gravel underlying similar areas (Helgesen, 1977, p. 15) and the results of a ground-water-flow-model analysis for the BemidjiBagley area (Stark and others, 1991, p. 22) to the west of the study area, the horizontal hydraulic conductivity of the unconfined aquifer probably ranges from 250 to $750 \mathrm{ft} / \mathrm{d}$. On the basis of estimates of hydraulic conductivity derived from specific-capacity information, Stark and others (1991, p. 22) reported the transmissivity of the aquifer ranges from less than 70 $\mathrm{ft}^{2} / \mathrm{d}$ to greater than $8,900 \mathrm{ft}^{2} / \mathrm{d}$ (horizontal hydraulic conductivities from $1 \mathrm{ft} / \mathrm{d}$ to $200 \mathrm{ft} / \mathrm{d}$ ). Estimates of horizontal hydraulic conductivity derived from 19 slug tests conducted for this study range from $0.6 \mathrm{ft} / \mathrm{d}$ to 31 $\mathrm{ft} / \mathrm{d}$. Estimated hydraulic conductivities are greatest in 


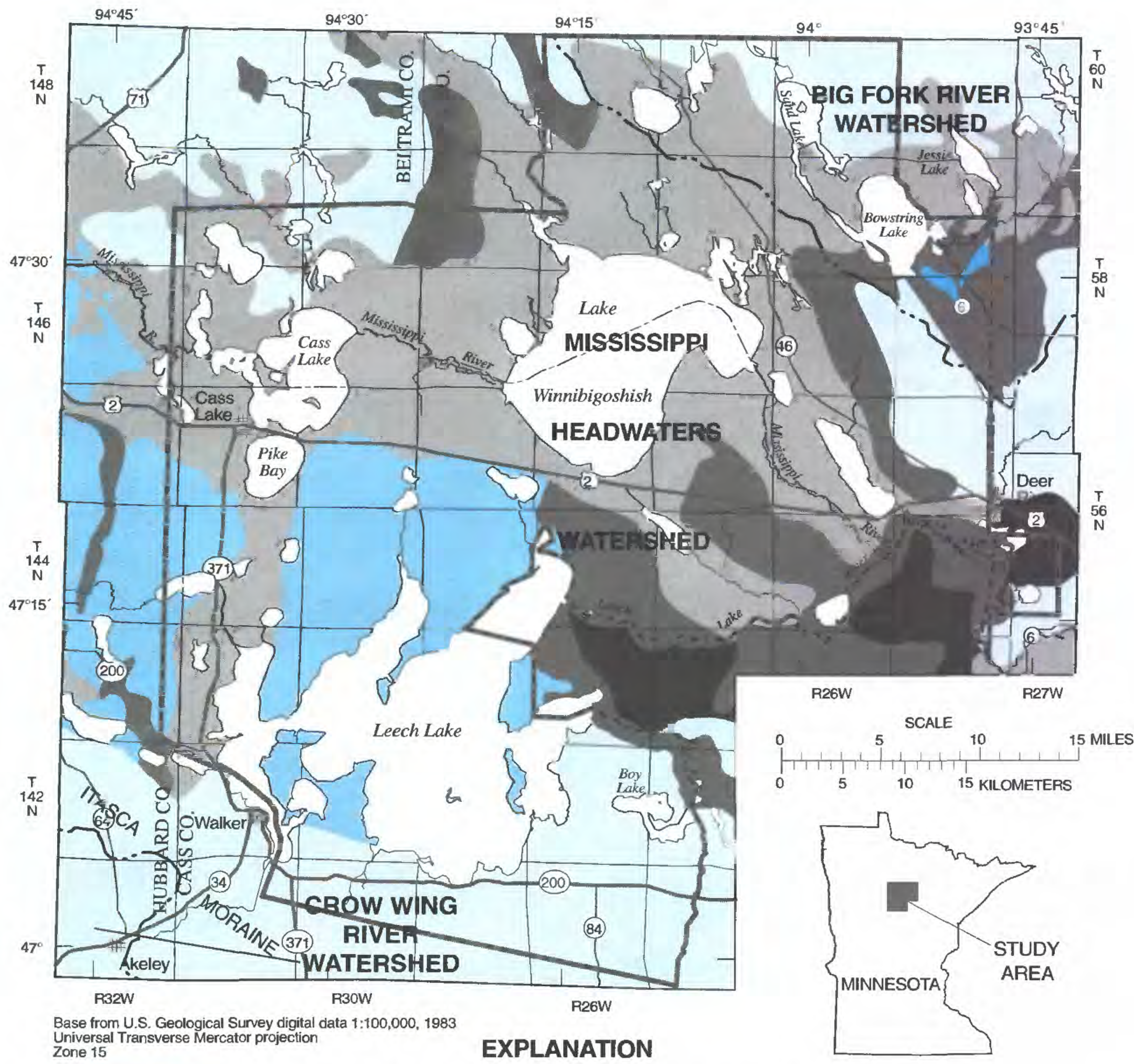

Till plain (Ground moraine)--Rolling uplands with some lakes

End moraine--Rolling and hilly topography with numerous lakes and potholes

Outwash sand--Distribution underlies present and former drainage ways.

Generally corresponds to distribution of surficial sand aquifers.

Glacial lake peat deposit--Flat topography or pothole fillings

Glacial lake silt, sand, and clay--Flat topography

Glacial lake modified till--Flat to gently rolling topography

Leech Lake Indian Reservation boundary

-Watershed divide

Figure 7. Quaternary geology of the study area (modified from Oakes and Bidwell (1968), Lindholm and others (1972), and Lindholm and others (1976)). 


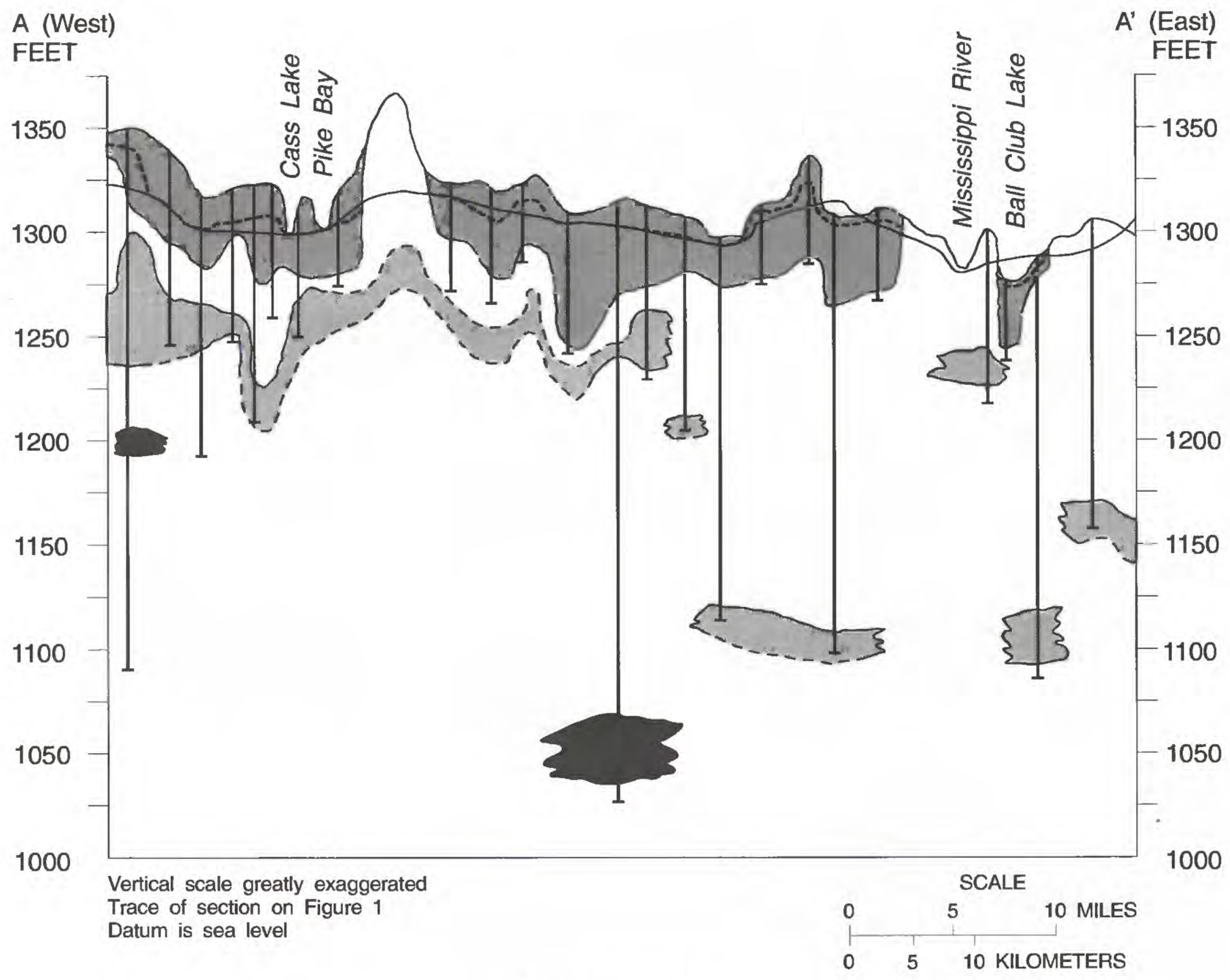

EXPLANATION

Unconfined aquifer

Uppermost confined aquifer (dashed where inferred). The uppermost confined aquifer is considered as a single hydrogeologic unit in this report. However, the aquifer probably is physically discontinuous in some areas and may consist of several aquifers separated by units of low hydraulic conductivity.

Confined aquifers below uppermost confined aquifer

Confining units, composed of clay and till

Potentiometric surface of unconfined aquifer

Potentiometric surface of uppermost confined aquifer

1 Well or test hole

Figure 8. Hydrogeologic units in the study area, Leech Lake Indian Reservation, Minnesota. 


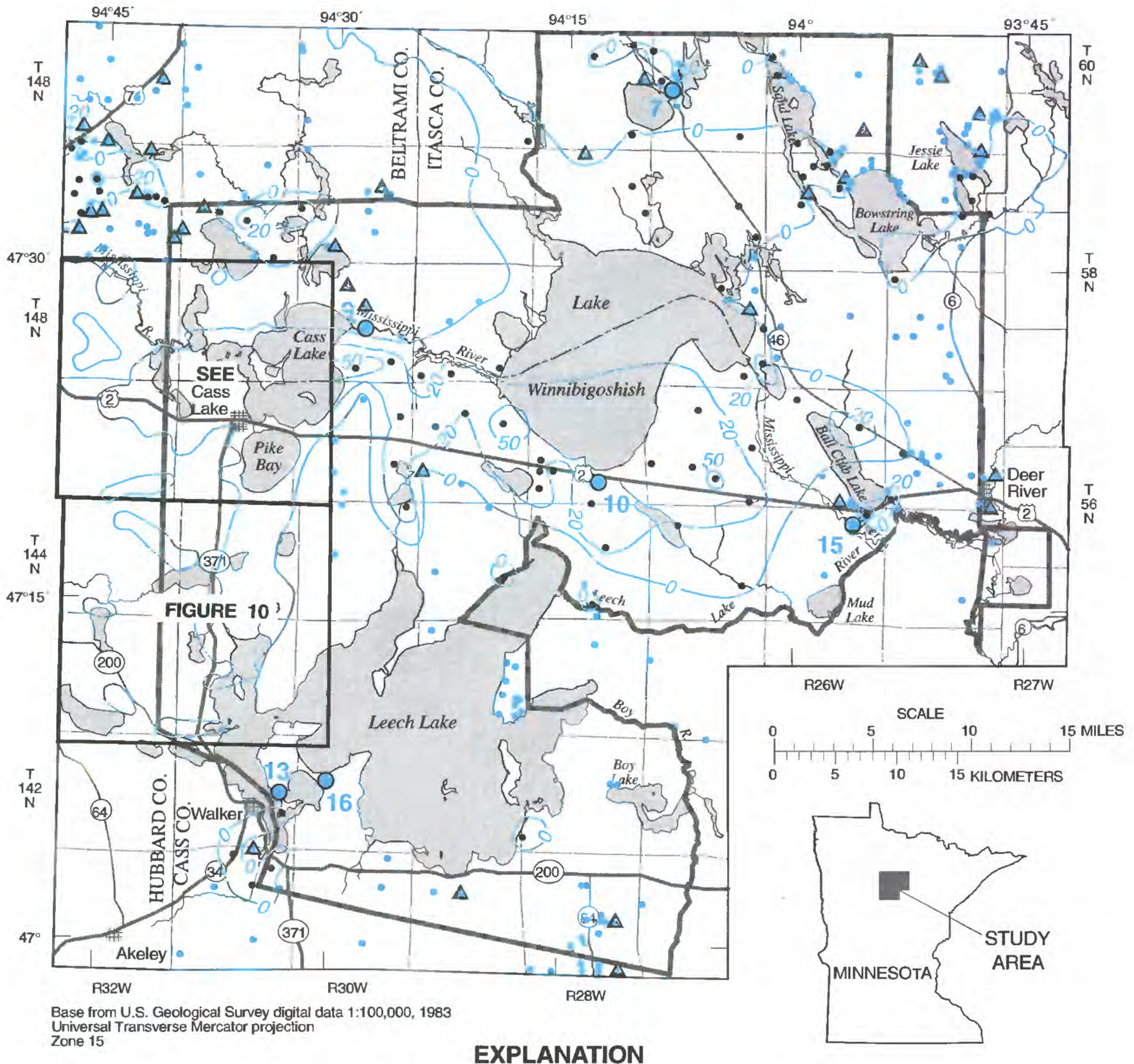

Leech Lake Indian Reservation boundary

Line of equal saturated thickness of unconfined aquifer--Interval in feet, is variable.

Dashed where inferred.

$0^{9} \quad$ Cluster of closely-spaced well sites--Number indicates number of wells in cluster

Well site or test hole:

- Unconfined aquifer present

- Clay or till present at land surface

$\Delta \quad$ Unsaturated sand overlies uppermost confining unit

Figure 9. Saturated thickness of the unconfined aquifer. 


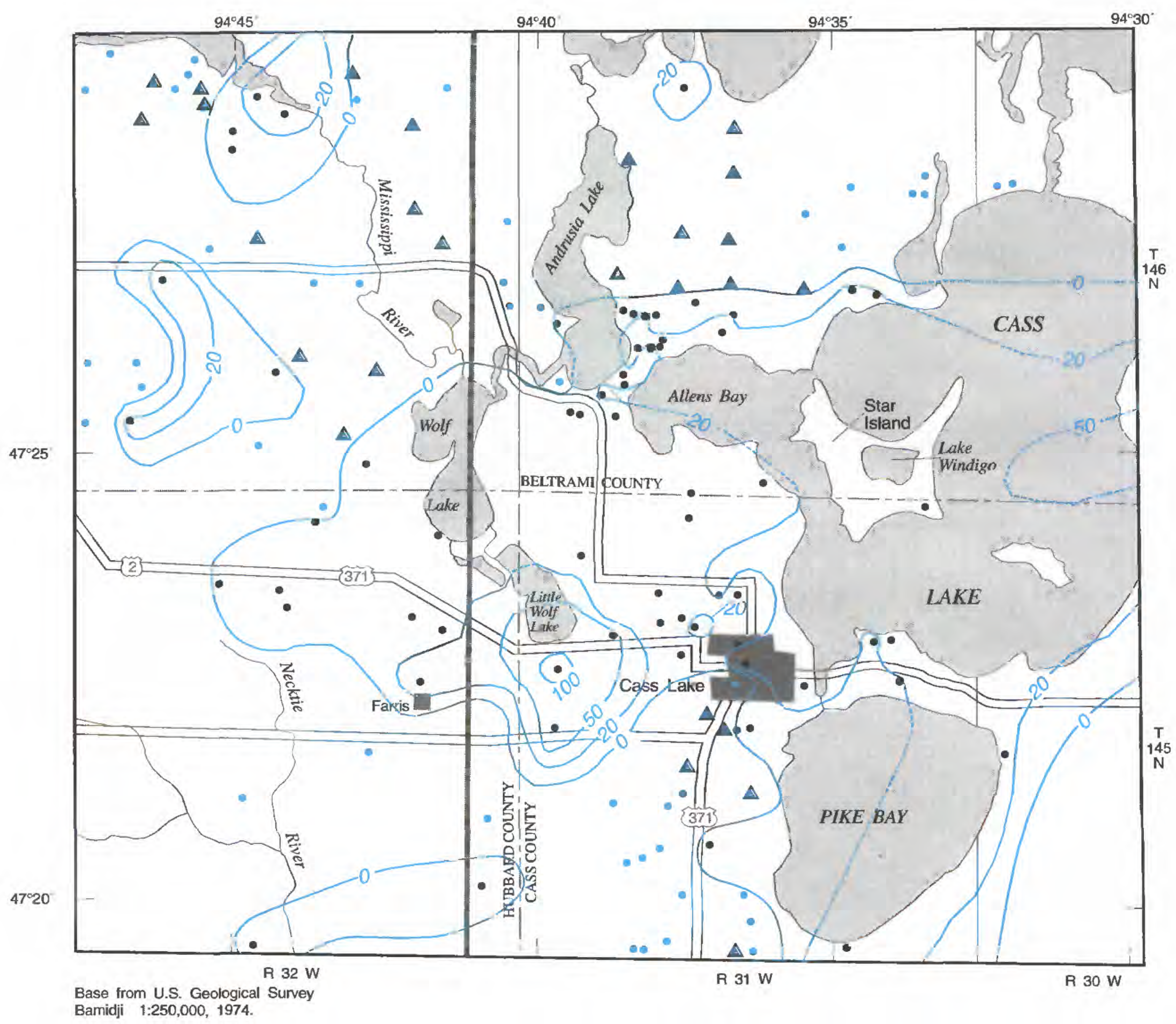

EXPLANATION

Leech Lake Indian Reservation boundary

Line of equal saturated thickness of unconfined aquifer--Interval in feet, is variable. Dashed where inferred.

Well site or test hole:

- Unconfined aquifer present

- Clay or till present at land surface

A Unsaturated sand overlies uppermost confining unit

Figure 10. Saturated thickness of the unconfined 

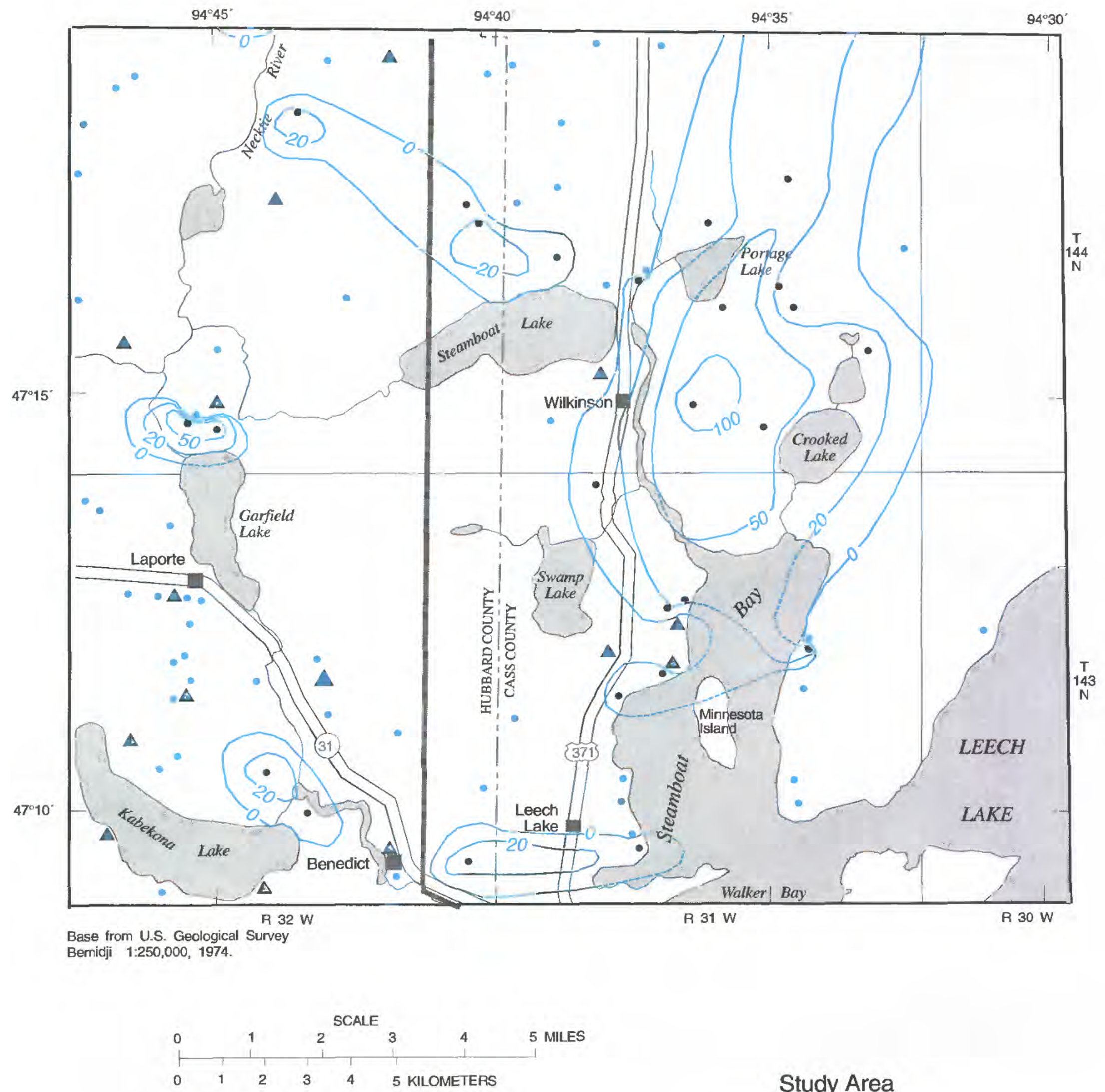

\section{Study Area}

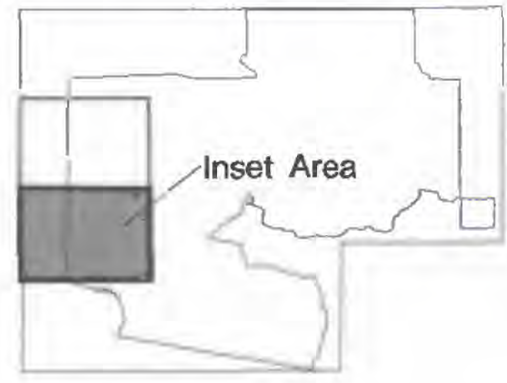

aquifer in the vicinity of Cass and Leech Lakes. 
the area from west of Cass Lake to Lake

Winnibigoshish. The corresponding range in transmissivity is from 19 to $1,960 \mathrm{ft}^{2} / \mathrm{d}$. Figure 11 shows the transmissivity of the unconfined aquifer.

The transmissivity of the aquifer in the study area ranges from $19 \mathrm{ft}^{2} / \mathrm{d}$ to more than $20,000 \mathrm{ft}^{2} / \mathrm{d}$, based on transmissivities derived from 19 slug tests and from specific-capacity information for 7 wells. The transmissivity of the aquifer is greatest in the area from west of Cass Lake to Lake Winnibigoshish. Specificcapacity information was obtained from data reported on driller's logs. These logs often report no drawdown in pumping wells during development. Specificcapacity data based on this information may reflect inadequate measurements. Disregarding data reporting no drawdown may have resulted in excluding data from the most transmissive portions of the aquifer.

Additional drilling and aquifer tests would be required to better refine estimates of the hydraulic properties of the aquifer.

Horizontal hydraulic conductivities and transmissivities estimated from slug tests are often lower than the corresponding values estimated from specific-capacity data. Slug test results are representative of the aquifer material in the immediate vicinity of the borehole, whereas specific-capacity or aquifer-test data are representative of the aquifer material in a larger area surrounding the borehole. The often lower estimated transmissivity values derived from slug tests may indicate an envelope of fine-grained aquifer material in the immediate vicinity of the boreholes, due to well-construction and welldevelopment methods. In this report, estimated transmissivities derived from specific-capacity or aquifer-test data are considered to be more representative of the aquifer as a whole.

Reported well yields are generally less than 250 $\mathrm{gal} / \mathrm{min}$, but may be $2,000 \mathrm{gal} / \mathrm{min}$ in some areas. The limited thickness of the aquifer over most of the area limits the potential productivity of the aquifer as a source of ground water to wells.

Theoretical maximum well yields, computed from specific capacity values, range from about 30 to more than $1,600 \mathrm{gal} / \mathrm{min}$ in the unconfined aquifer. Theoretical maximum well yields, derived from the results of slug tests for 19 wells and from specificcapacity information for 7 wells, range from less than 10 to about $2,000 \mathrm{gal} / \mathrm{min}$. Theoretical maximum well yields generally exceed $100 \mathrm{gal} / \mathrm{min}$ in the area of Cass Lake to Lake Winnibigoshish and are generally less than $100 \mathrm{gal} / \mathrm{min}$ for the rest of the study area (fig. 12).

Local deviation from theoretical maximum yields are caused by local variations in aquifer hydraulic properties, recharge, proximity of the well to other pumping wells, effects of hydrologic boundaries (for example, rivers or the edge of the aquifer), well diameter and efficiency, and duration of pumping. The theoretical maximum well yields given for this study are intended to show only general conditions and relative differences in water-yielding capability. Well yields for the unconfined aquifer may be significantly lower than shown on the map in areas where drawdown significantly reduces the saturated thickness of the unconfined aquifer. The map (fig. 12) cannot be used for accurate projection of well yields at a given location.

The areas of greatest theoretical maximum yield coincide with areas of greatest transmissivity. Highcapacity wells generally are best located in these areas.

\section{Uppermost confining unit}

The unconfined and uppermost confined aquifers are physically and hydraulically separated by a fine-grained confining unit consisting of till or lake deposits. The thickness and hydraulic properties of this confining unit vary spatially. The degree to which the confining unit isolates flow in the two aquifers is a function of the spatial variability of these properties. Figures 13 and 14 show the thickness of the uppermost confining unit. The thickness of the confining unit ranges from 3 to 254 feet in the study area. In areas where the unconfined aquifer is absent, the uppermost confining unit extends from the land surface to the top of the uppermost confined aquifer. The thickness of the confining unit is greatest near Jessie Lake in the northeastern part of the study area and southeast of Lake Winnibigoshish and generally is least in the western part of the study area.

Although no field tests were made for this study, the horizontal hydraulic conductivity of till in the study area can be estimated based on the results of previous work in other areas. A value of $1 \mathrm{ft} / \mathrm{d}$ for the horizontal hydraulic conductivity of alluvial clay was given by Lohman (1972, p. 53). A value of about $0.5 \mathrm{ft} / \mathrm{d}$ is at the upper limit for horizontal hydraulic conductivity values for till given by Heath (1983, p. 13). Stark and others (1991, p. 23) reported that ground-water-flow model analysis indicated values from 0.1 to $1.0 \mathrm{ft} / \mathrm{d}$ are reasonable values of horizontal hydraulic conductivity for the uppermost confining unit in the Bemidji-Bagley area. 


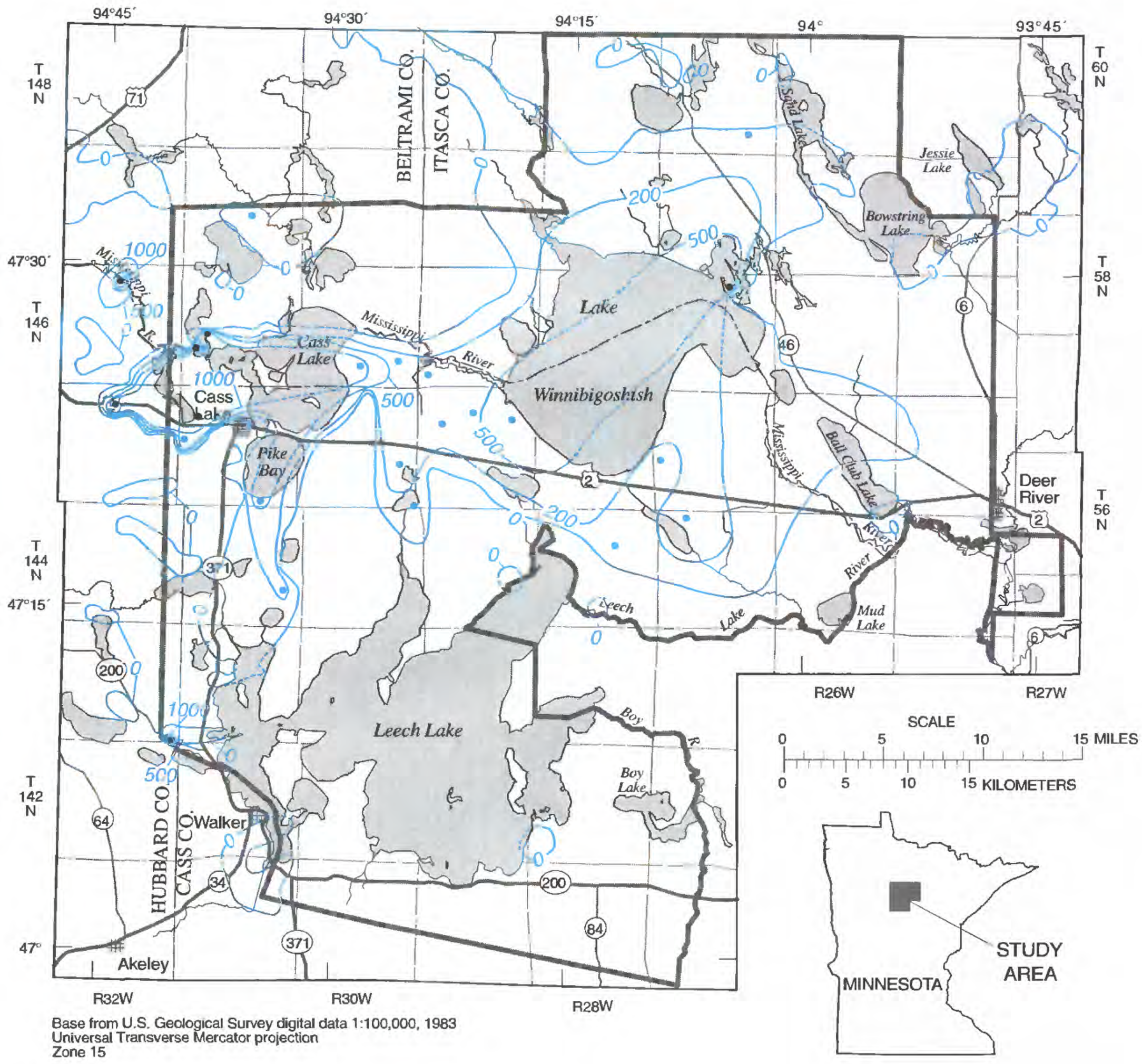

EXPLANATION

- Leech Lake Indian Reservation boundary Line of equal transmissivity of unconfined aquifer--Interval, in feet squared per day, is variable. Dashed where inferred.

- Well log used for control--Blue circle is transmissivity derived from slug test data. Black circle is transmissivity derived from specific-capacity data.

Figure 11. Transmissivity of the unconfined aquifer. 


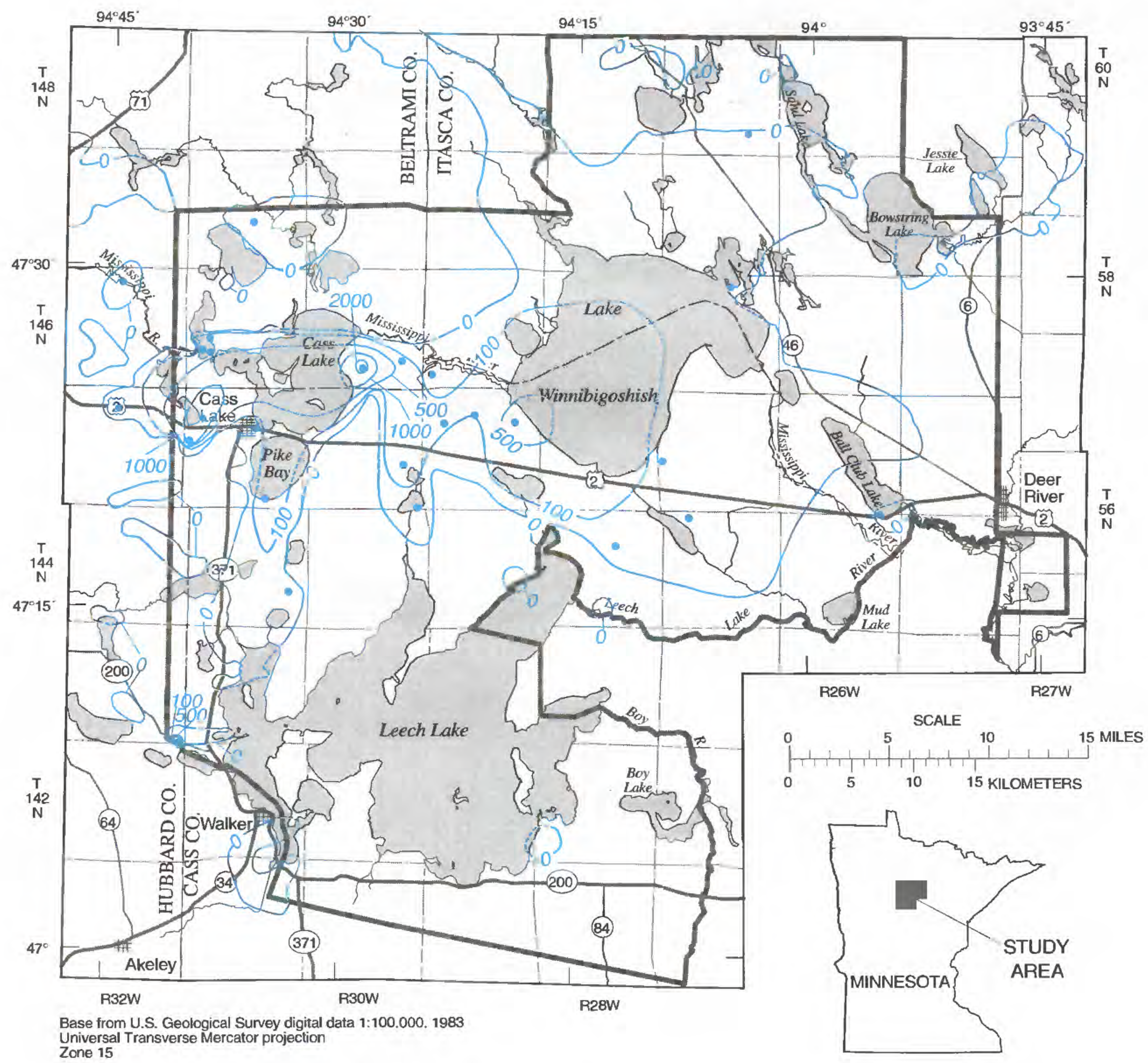

EXPLANATION

Leech Lake Indian Reservation boundary

- 100 - Line of equal theoretical maximum well yield of unconfined aquifer--Interval, in gallons per minute, is variable. Dashed where inferred.

- Well log used for control

Figure 12. Theoretical maximum well yield of the unconfined aquifer. 


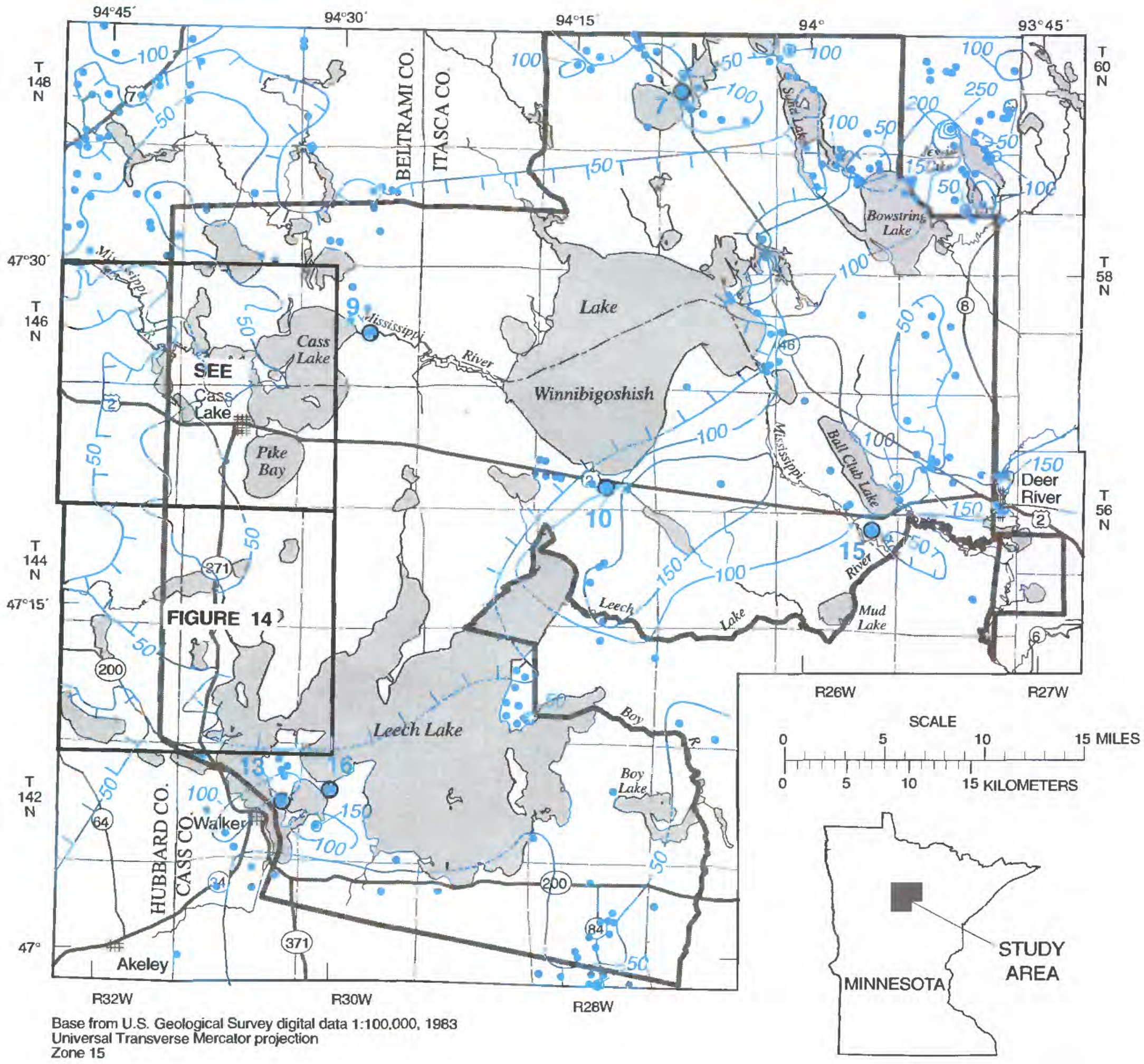

EXPLANATION

Leech Lake Indian Reservation boundary

- 100 - Line of equal thickness of uppermost confining unit--Hachures indicate thickness less than 50 . Interval 50 feet. Dashed where inferred.

- 16 Cluster of closely-spaced well sites--Number indicates number of wells in cluster

- Well log used for control

Figure 13. Thickness of the uppermost confining unit. 


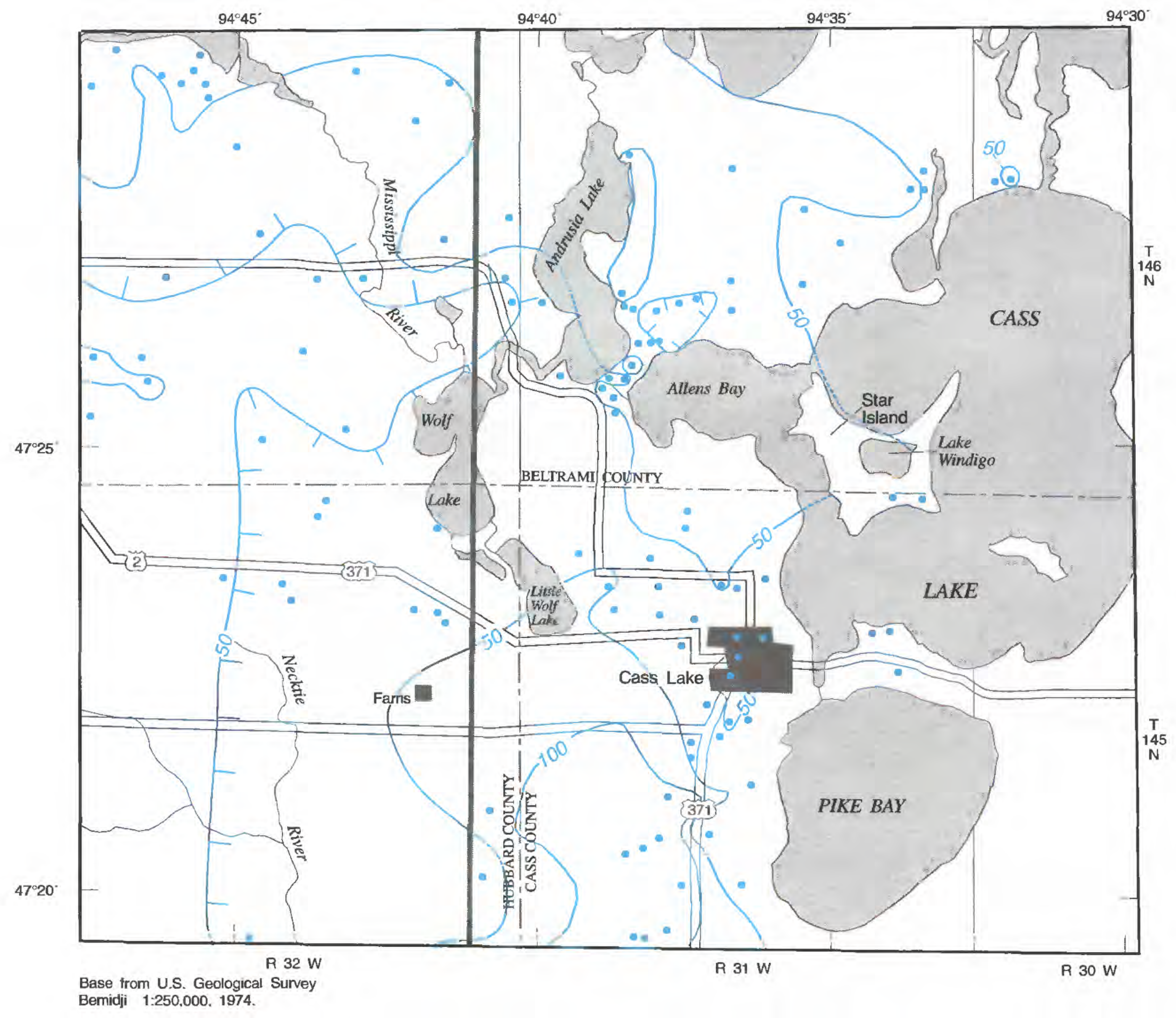

EXPLANATION

Leech Lake Indian Reservation boundary

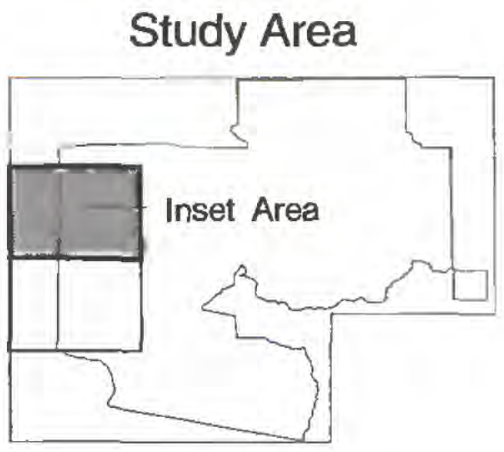

Figure 14. Thickness of the uppermost confining 

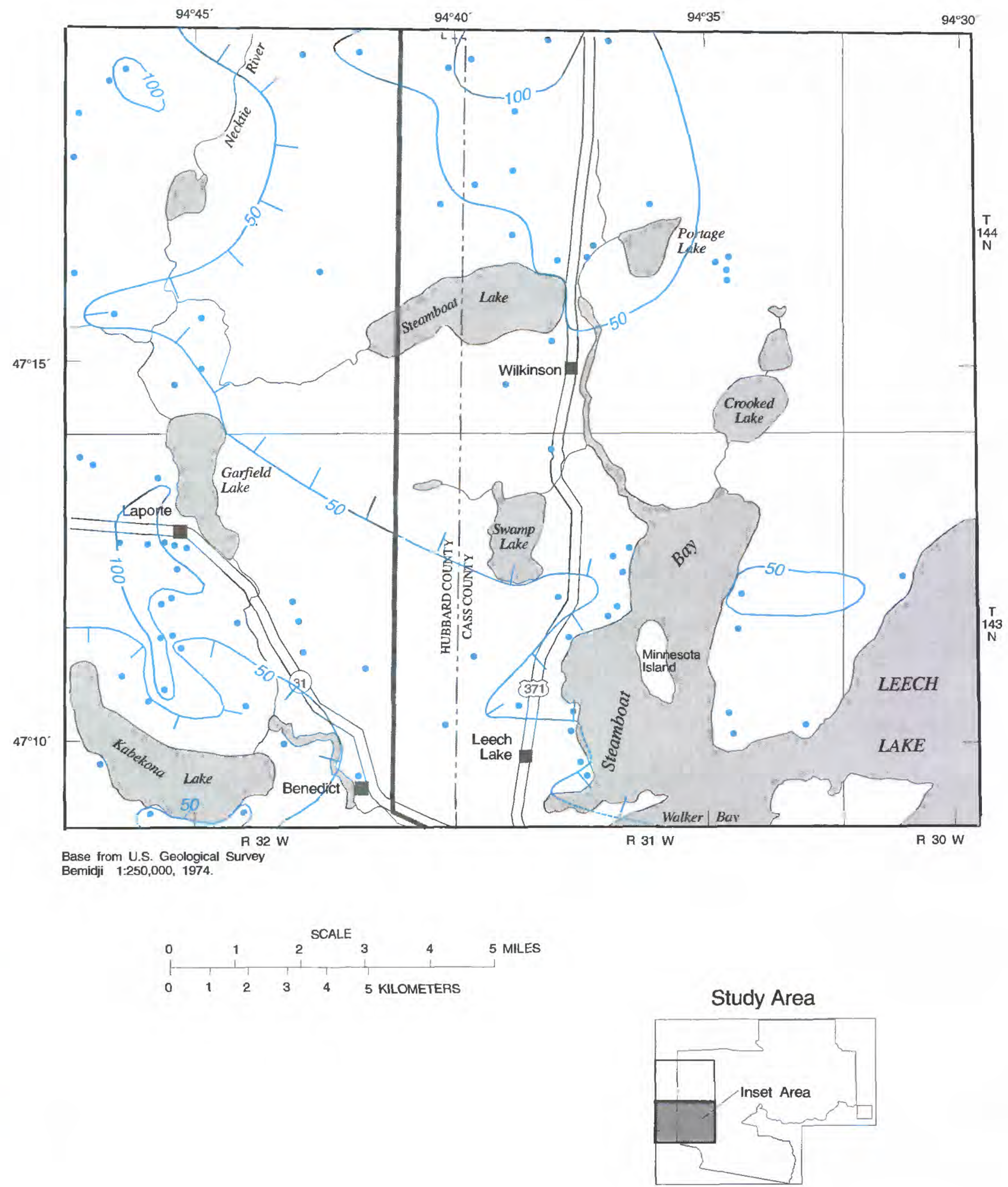

unit in the vicinity of Cass and Leech Lakes. 
Vertical flow of water between the unconfined and the uppermost confined aquifers depends on (1) the thickness and vertical hydraulic conductivity of the confining unit, and (2) the differences in hydraulic head of the aquifers above and below the confining unit. The vertical hydraulic conductivity of till and glacial-lake deposits generally is much lower than the hydraulic conductivity of sand and gravel deposits. On the basis of analysis of 12 aquifer tests, Delin (1986, p. 12) estimated the mean vertical hydraulic conductivity of till in the area of Morris, Minn., to be $2.5 \times 10^{-2} \mathrm{ft} / \mathrm{d}$. This value is similar to the value of $1.8 \times 10^{-2} \mathrm{ft} / \mathrm{d}$ for the vertical hydraulic conductivity of till in the Detroit Lakes area of Minnesota (Miller, 1982, p. 39). These values of vertical hydraulic conductivity of till are higher than those reported for other parts of the glaciated northern United States and reflect the sandrich characteristic of till in many parts of Minnesota. Permeameter tests conducted by Prudic (1982, p. 200) indicate that the vertical hydraulic conductivity of till in New York ranges from $3.1 \times 10^{-5}$ to $4.3 \times 10^{-4} \mathrm{ft} / \mathrm{d}$. Although significant volumes of water flow between the unconfined and confined aquifers on a regional scale in the study area, the confining unit serves as an effective barrier to the rapid exchange of ground water between the aquifers.

\section{Uppermost confined aquifer}

Confined aquifers within the glacial drift consist of buried deposits of sand and gravel that are bounded above by confining units of till or lake deposits. Numerous confined aquifers probably exist with depth in the study area but little information is available about confined aquifers below the uppermost confined aquifer; therefore, only the uppermost confined aquifer, the primary source of ground water to wells in the study area, is discussed. The thickness and extent of the uppermost confined aquifer was determined from logs of domestic wells, which generally do not penetrate the entire thickness of the aquifer. In some cases, wells were screened in deeper aquifers that underlie the uppermost confined aquifer. A lack of domestic-well $\operatorname{logs}$ that penetrate the entire thickness of the aquifer introduces uncertainty in the mapping of aquifer thickness in many areas.

The uppermost confined aquifer is considered as a single hydrogeologic unit in this report. The aquifer probabily is physically discontinuous in some areas and may consist of several aquifers separated by units of low hydraulic conductivity. Data are not sufficient to map those discontinuities at the scale of this project.

The altitude at the top of the uppermost confined aquifer ranges from about $1,110 \mathrm{ft}$ southeast of Lake
Winnibigoshish to $1,350 \mathrm{ft}$ above sea level in the northwestern part of the study area. Figures 15 and 16 show the altitude at the top of the uppermost confined aquifer. The top of the aquifer generally slopes from the boundaries of the study area toward the three large lakes (Cass Lake, Leech Lake, and Lake Winnibigoshish) and toward the Mississippi River in the eastern part of the area. The thickness of the aquifer ranges from 5 to about $53 \mathrm{ft}$. The thickness generally is greatest in the southeastern part of the study area and least in the northcentral and eastern parts (fig. 17). The well-log locations included on figure 17 are locations where the well boring penetrated at least $10 \mathrm{ft}$ of the aquifer.

The horizontal hydraulic conductivity of the uppermost confined aquifer ranges from 250 to $750 \mathrm{ft} / \mathrm{d}$, on the basis of published values of horizontal hydraulic conductivity for sand and gravel deposits from similar studies (Heigesen, 1977, p. 13), and from the results of a ground-water-flow model analysis for the BemidjiBagley area (Stark and others, 1991, p. 34). On the basis of specific-capacity data from domestic well logs, the transmissivity of the aquifer ranges from less than $100 \mathrm{ft}^{2} / \mathrm{d}$ in the northeastern and southeastern parts of the study area to about $21,000 \mathrm{ft}^{2} / \mathrm{d}$ near Cass Lake. The transmissivity of the aquifer exceeds $5,000 \mathrm{ft}^{2} / \mathrm{d}$ in the northwestern and southwestern parts of the study area and ranges from about 1,000 to $3,000 \mathrm{ft}^{2} / \mathrm{d}$ for much of the rest of the area. Figure 18 shows the transmissivity of the uppermost confined aquifer.

Well yields of about $2,600 \mathrm{gal} / \mathrm{min}$ are reported in some locations. The scant thickness of the aquifer over parts of the study area limits the potential of the aquifer as a source of ground water to wells. Theoretical maximum well yields, computed from specific capacity values, range from less than 10 to about $2,600 \mathrm{gal} / \mathrm{min}$ in the uppermost confined aquifer. Theoretical maximum well yields exceed $400 \mathrm{gal} / \mathrm{min}$ in the Cass Lake and Leech Lake areas and generally are less than $400 \mathrm{gal} / \mathrm{min}$ elsewhere in the study area (fig. 19).

\section{Recharge}

Recharge to the ground-water system (unconfined aquifer, uppermost confining unit, and uppermost confined aquifer) predominantly is from precipitation that infiltrates to the saturated zone. Other sources of recharge to the ground-water system in the study area are leakage from lakes and streams locally, and underflow from the west, north, and south. Recharge to the aquifers from infiltration of precipitation is greatest and most rapid in areas where the sand and gravel comprising the unconfined aquifer is present at the land surface. Recharge and hydraulic heads (water levels) in the unconfined aquifer tend to follow a short-term cyclic 


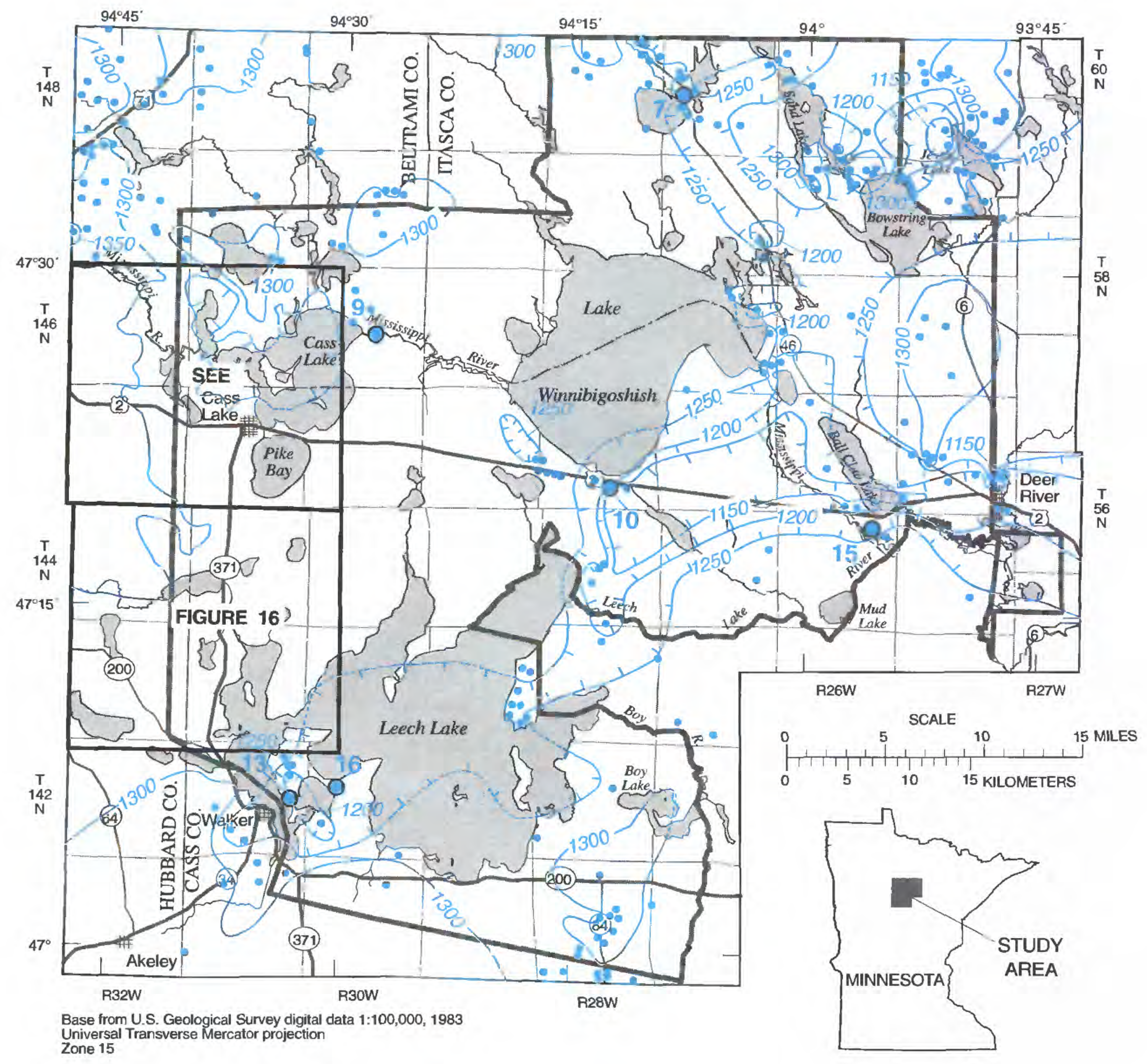

EXPLANATION

Leech Lake Indian Reservation boundary

- 1300 - Structure contour--Shows altitude of top of uppermost confined aquifer. Hachures indicate depression. Interval 50 feet. Datum is sea level. Dashed where inferred

- 16 Cluster of closely-spaced well sites--Number indicates number of wells in cluster

- Well log used for control

Figure 15. Altitude at the top of uppermost confined aquifer. 


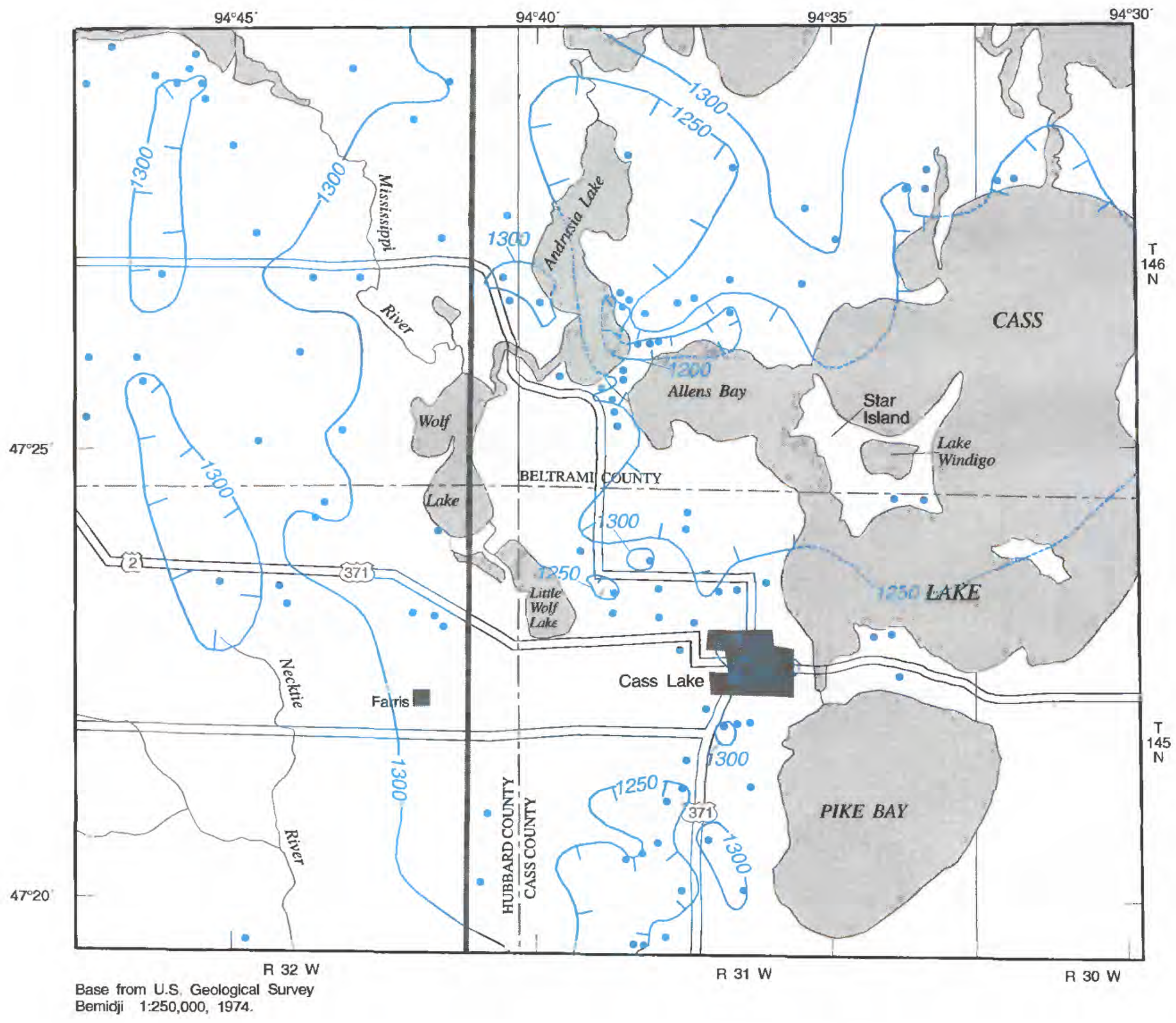

EXPLANATION

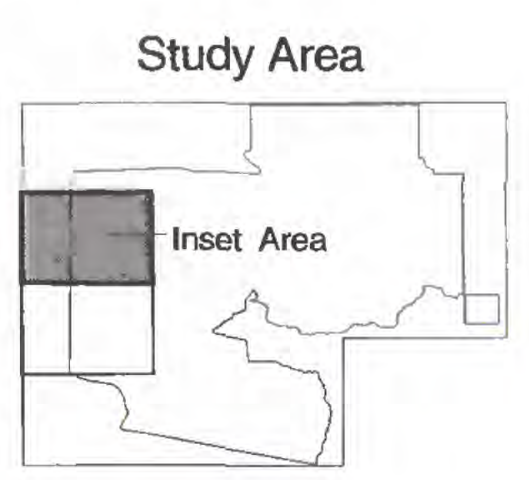

Leech Lake Indian Reservation boundary

-1300 - Structure contour--Shows altitude of top of uppermost confined aquifer. Hachures indicate depression. Interval 50 feet. Datum is sea level. Dashed where inferred.

- Well log used for control

Figure 16. Altitude at the top of uppermost confined 

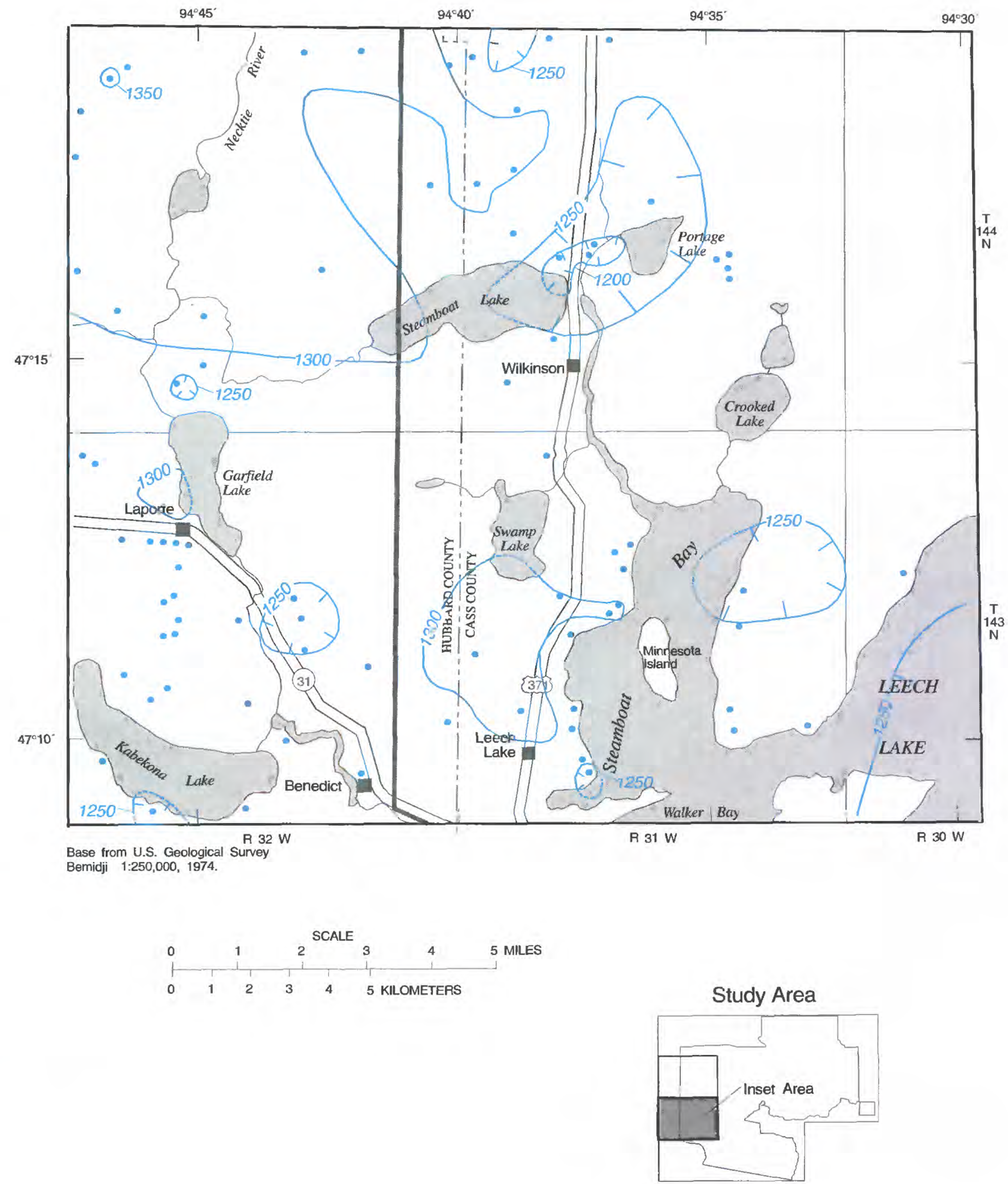

aquifer in the vicinity of Cass and Leech Lakes. 


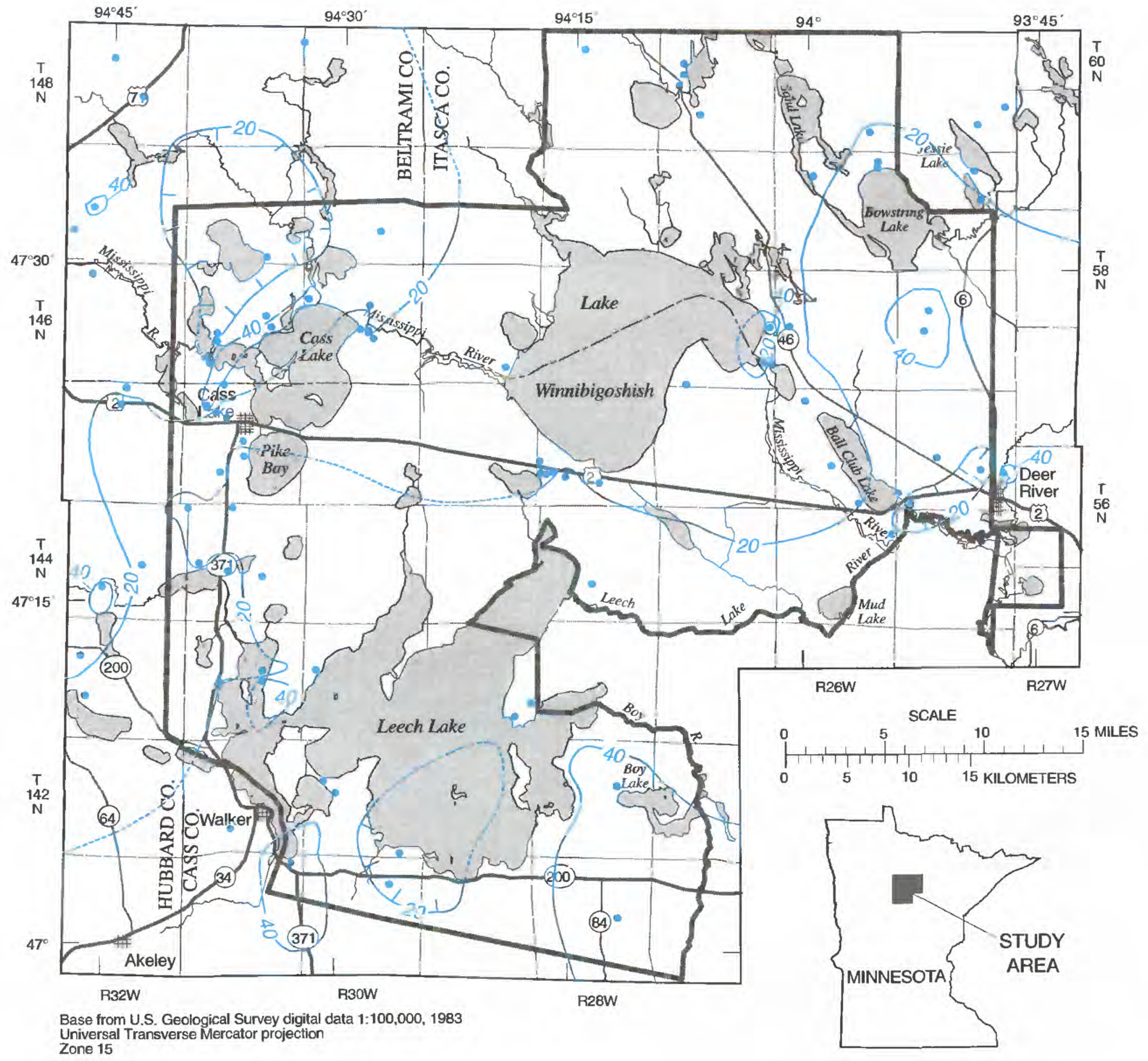

EXPLANATION

Leech Lake Indian Reservation boundary

Line of equal thickness of uppermost confined aquifer--Hachures indicates thickness less than 20. Interval 20 feet. Dashed where inferred.

- Well log used for control

Figure 17. Thickness of the uppermost confined aquifer. 


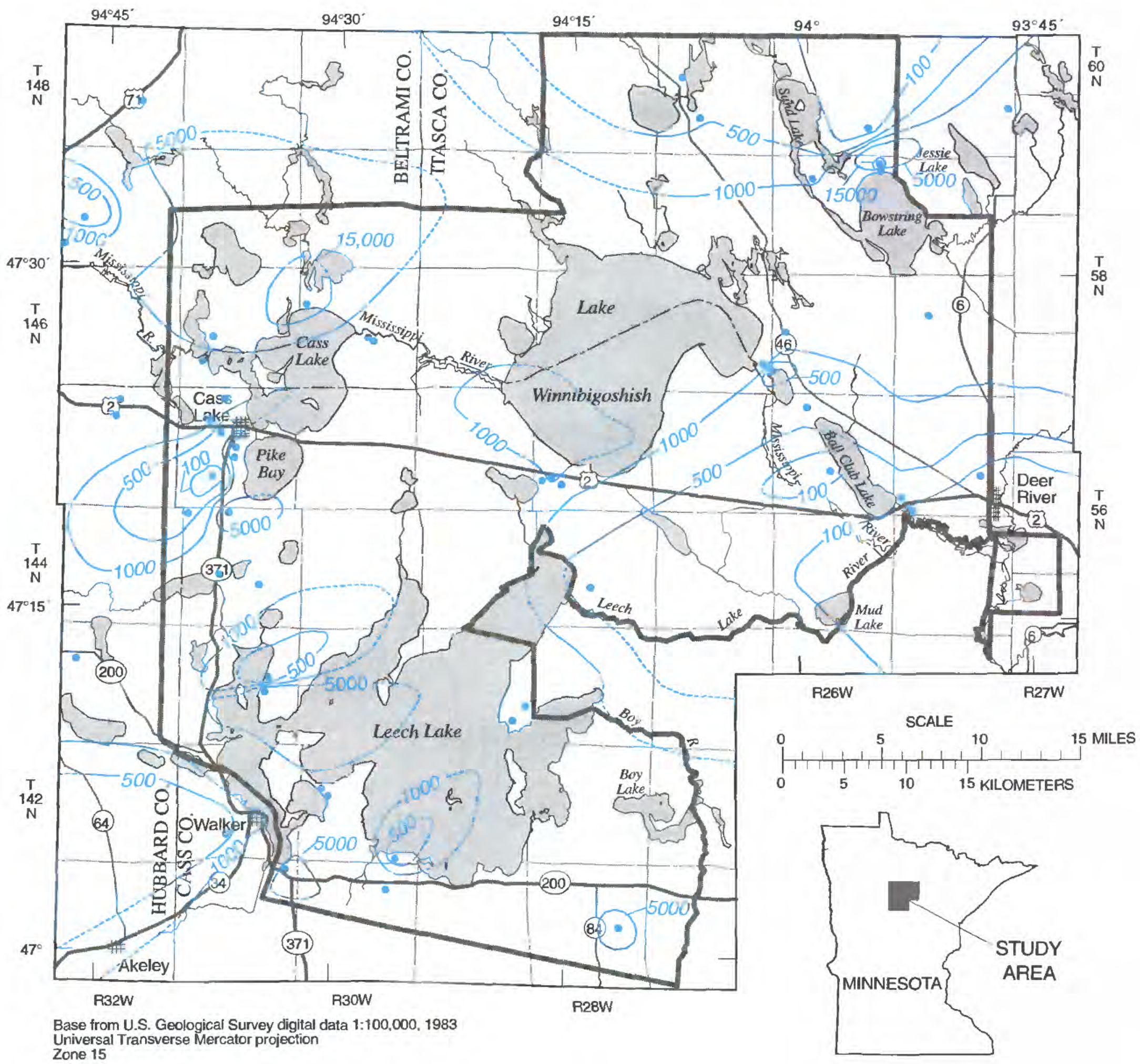

EXPLANATION

Leech Lake Indian Reservation boundary

- 500 - Line of equal transmissivity of uppermost confined aquifer--Interval is variable, in feet squared per day. Dashed where inferred

- Well log used for control

Figure 18. Transmissivity of the uppermost confined aquifer. 


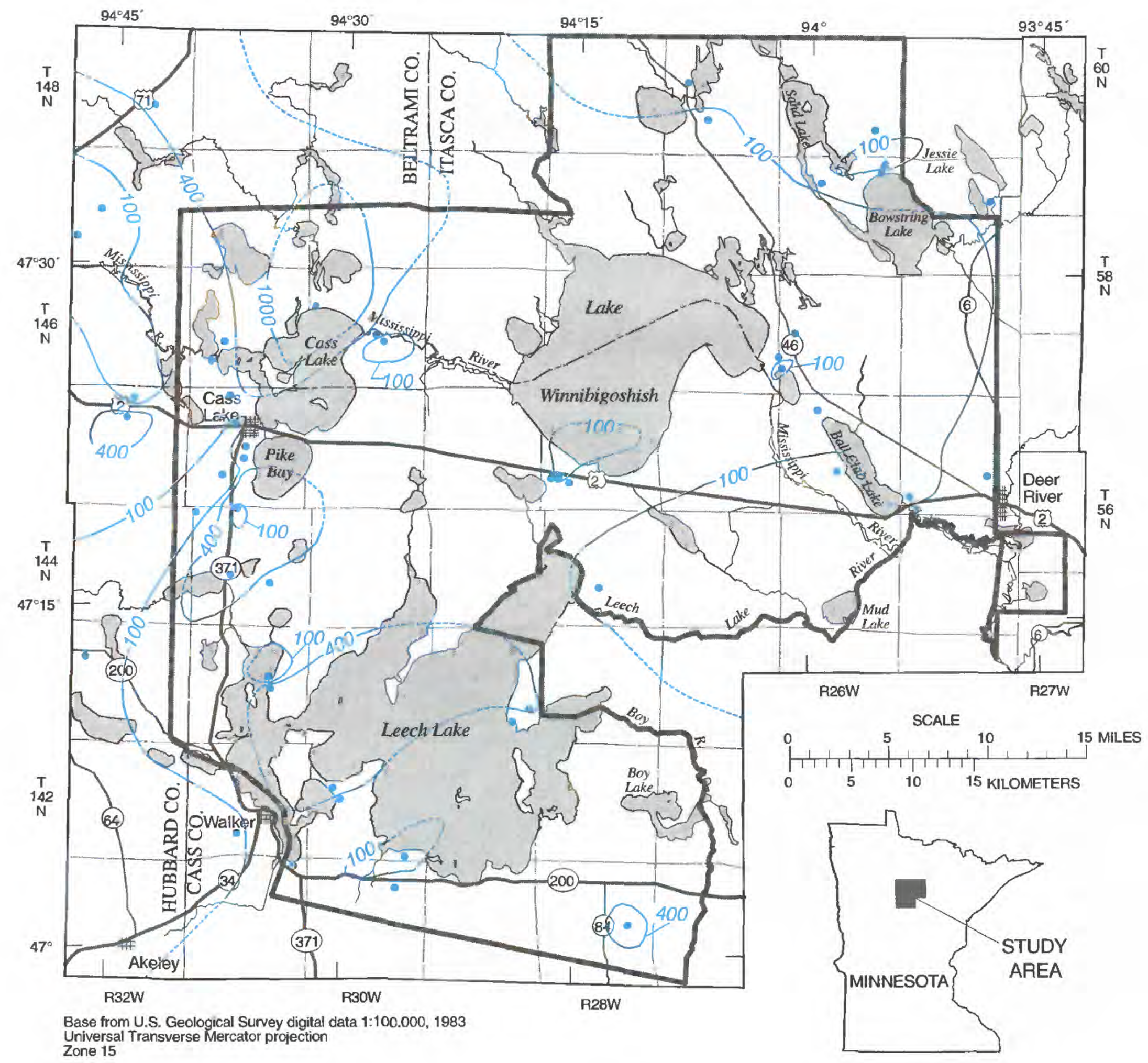

EXPLANATION

Leech Lake Indian Reservation boundary

Line of equal theoretical maximum well yield of uppermost confined aquifer--Interval is variable, in gallons per minute. Dashed were inferred

- Well log used for control

Figure 19. Theoretical maximum well yield of the uppermost confined aquifer. 
pattern of seasonal fluctuations. Hydraulic heads in the unconfined aquifer generally are highest in the spring, during maximum recharge from snowmelt and rainfall; decline during the summer, when evapotranspiration losses are high and the amount of precipitation and infiltration to the water table is less; tend to level out, but continue downward, during the fall; are lowest during winter, when potential recharge from precipitation is stored at the land surface as snow; and rise again in the spring. Variations in the amount and timing of precipitation and subsequent recharge to the aquifer may result in deviations from this generalized pattern of fluctuations. Autumn rainfall, for example, may result in substantial recharge to the ground-water system and rises in hydraulic heads. Figure 20 illustrates seasonal water-level fluctuations in wells screened in the unconfined aquifer in the study area.

Recharge can be estimated from water-level measurements in observation wells (Rasmussen and Andreasen, 1959). This method assumes that all waterlevel rises in the well result from recharge to the aquifer. The water-level rise calculated by this method is based on a line projecting the recession line of the hydrograph to the date at which the peak occurred. A generic example is shown in figure 21 . The estimated annual recharge equals the difference between the peak stages and the projected water-level declines, multiplied by the specific yield of the unconfined aquifer, for all recharge events during the year. Stark and others (1991, p. 45) estimated that areal recharge, computed for 1986-87 using a hydrograph from an observation well completed in the unconfined aquifer at Bemidji, was 4 in./yr (inches per year). Stark and others (1991, p. 45) also reported that results from model simulations indicated that a recharge rate of 4-8 in./yr produced the best matches between model-simulated and measured water levels in wells. An analysis of four hydrographs for observation wells screened in the unconfined aquifer in the study area indicated spring recharge amounts during 1989 of 1-4 in.

Recharge to the ground-water system also occurs where till or lake clays are present at land surface. In highland morainal areas ground water flows vertically downward through till to the uppermost confined aquifer. Recharge rate generally is less in these areas because till has much lower hydraulic conductivity than sand. Stark and others (1991, p. 45) reported recharge rates in the Bemidji-Bagley area of 4-8 in./yr in areas where Wadena lobe till is exposed, and 0-4 in./yr in areas where Des Moines lobe till is exposed.

Figure 22 shows water-level fluctuations in two wells screened in the uppermost confined aquifer in the study area. The general seasonal pattern of water-level fluctuations observed in the unconfined and uppermost confined aquifers is similar. The water-level fluctuations in the uppermost confined aquifer generally are of lesser magnitude and may be delayed in time, however, as compared to fluctuations in the unconfined aquifer. The differences in the magnitude and timing of fluctuations are caused by the presence of the low permeability confining units overlying the uppermost confined aquifer. Differences in water-level fluctuations in the unconfined and uppermost confined aquifers also may be due to less interaction with surface-water bodies for the uppermost confined aquifer. Hydraulic heads in the unconfined aquifer may closely approximate changes in the water-surface elevation of surface-water bodies where the surface and ground water are hydraulically connected.

\section{Discharge}

Discharge from the ground-water system occurs by leakage to streams, lakes, and wetlands, evapotranspiration. withdrawals by wells, and underflow to the southeast within the Mississippi River Valley.

\section{Ground-water discharge to streams, lakes, and wetlands}

Ground-water discharge mostly occurs by leakage to streams, lakes, and wetlands. The Mississippi River, Leech Lake River, Boy River, Cass Lake, Leech Lake, and Lake Winnibigoshish are major ground-water discharge areas. Streamflow measurements were made on the Boy, Mississippi, and Leech Lake Rivers during January 1990 and February 1991 to estimate groundwater discharge to the rivers (base flow) (fig. 1).

Measured net streamflow gains in the Mississippi River in 1991 were (1) $64 \mathrm{ft}^{3} / \mathrm{s}$ in a 9.1 mile reach between Cass Lake and Lake Winnibigoshish $\left(7.0 \mathrm{ft}^{3} / \mathrm{s} / \mathrm{mi}\right)$ (cubic feet per second per mile), (2) $36 \mathrm{ft}^{3} / \mathrm{s}$ in a 10.8 mile reach between the Lake Winnibigoshish outlet and Highway $2\left(3.3 \mathrm{ft}^{3} / \mathrm{s} / \mathrm{mi}\right)$, and (3) $26 \mathrm{ft}^{3} / \mathrm{s}$ in a $6.0 \mathrm{mi}$ reach between Highway 2 and immediately below the confluence of the Mississippi and Leech Lake Rivers $\left(4.3 \mathrm{ft}^{3} / \mathrm{s} / \mathrm{mi}\right)$. The measurements indicate that groundwater discharge to the Mississippi River is greater in the western part of the study area between Cass Lake and Lake Winnibigoshish than in the eastern part downstream from Lake Winnibigoshish. The measured net streamflow gain in the Leech Lake River in 1991 was $7 \mathrm{ft}^{3} / \mathrm{s}$ in a 19.2 mile reach from Federal Dam to about one mile above the confluence of the Mississippi 


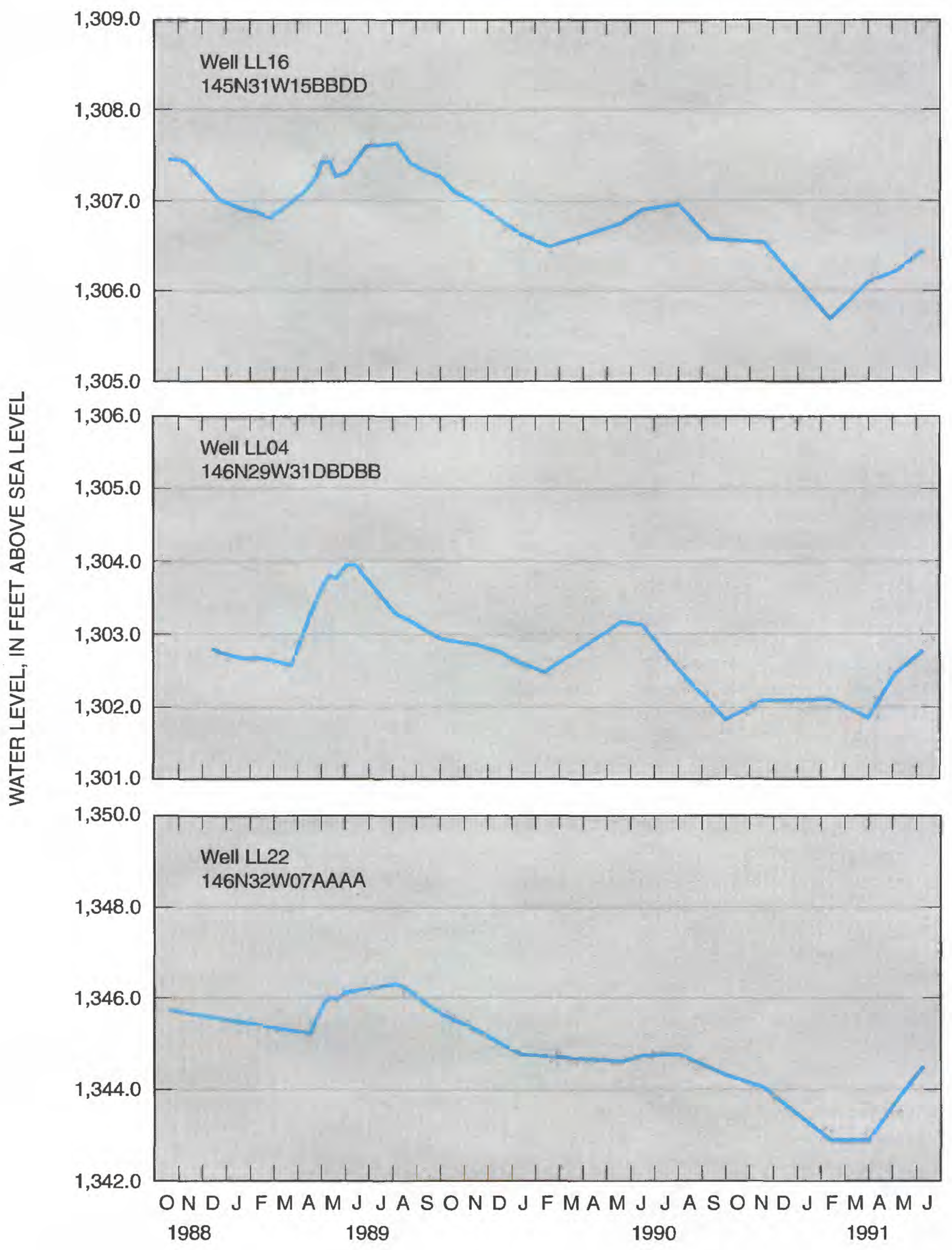

Figure 20. Water levels in wells screened in the unconfined aquifer, 1988-91, 


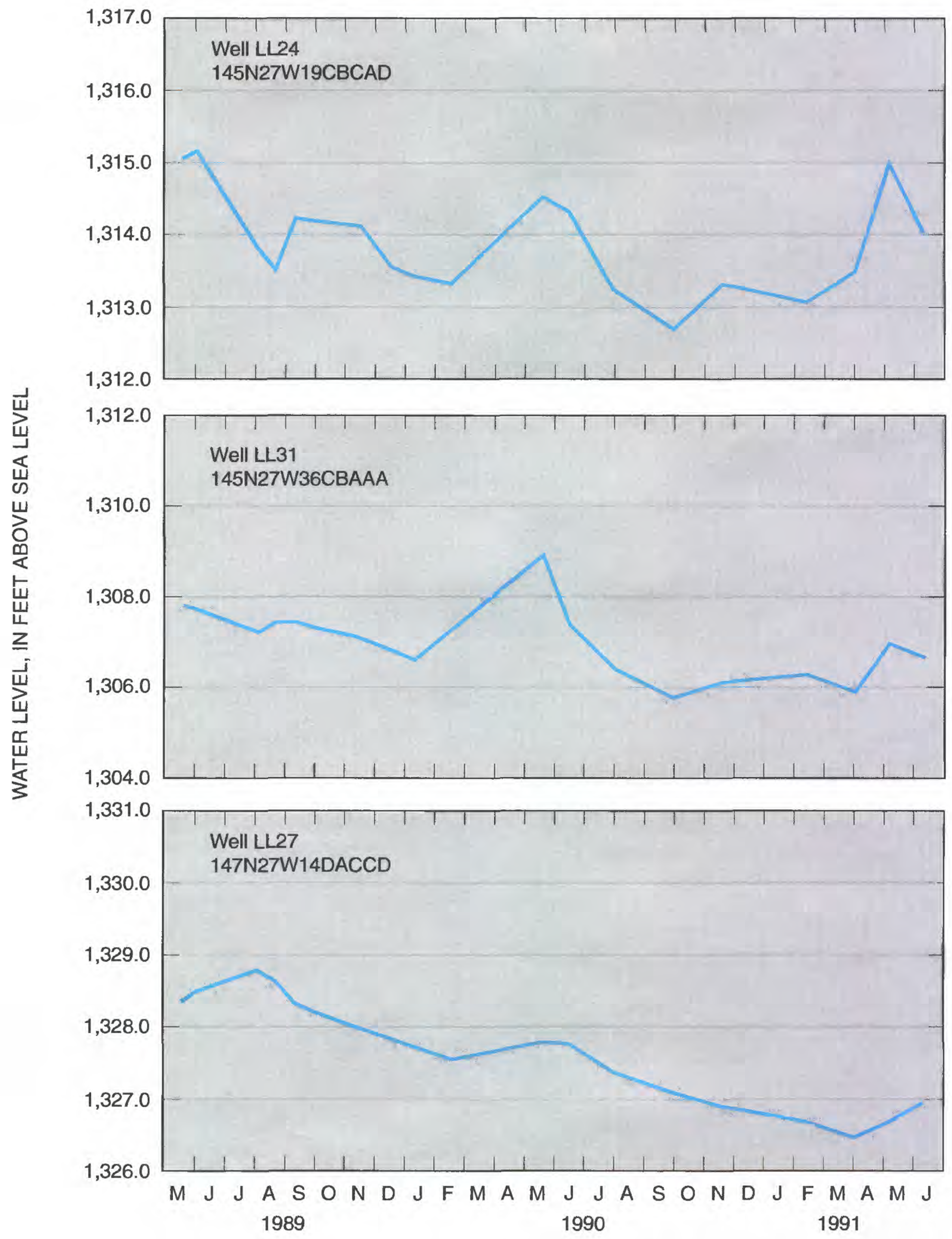

Leech Lake Indian Reservation, Minnesota (location of wells shown in figure 1). 


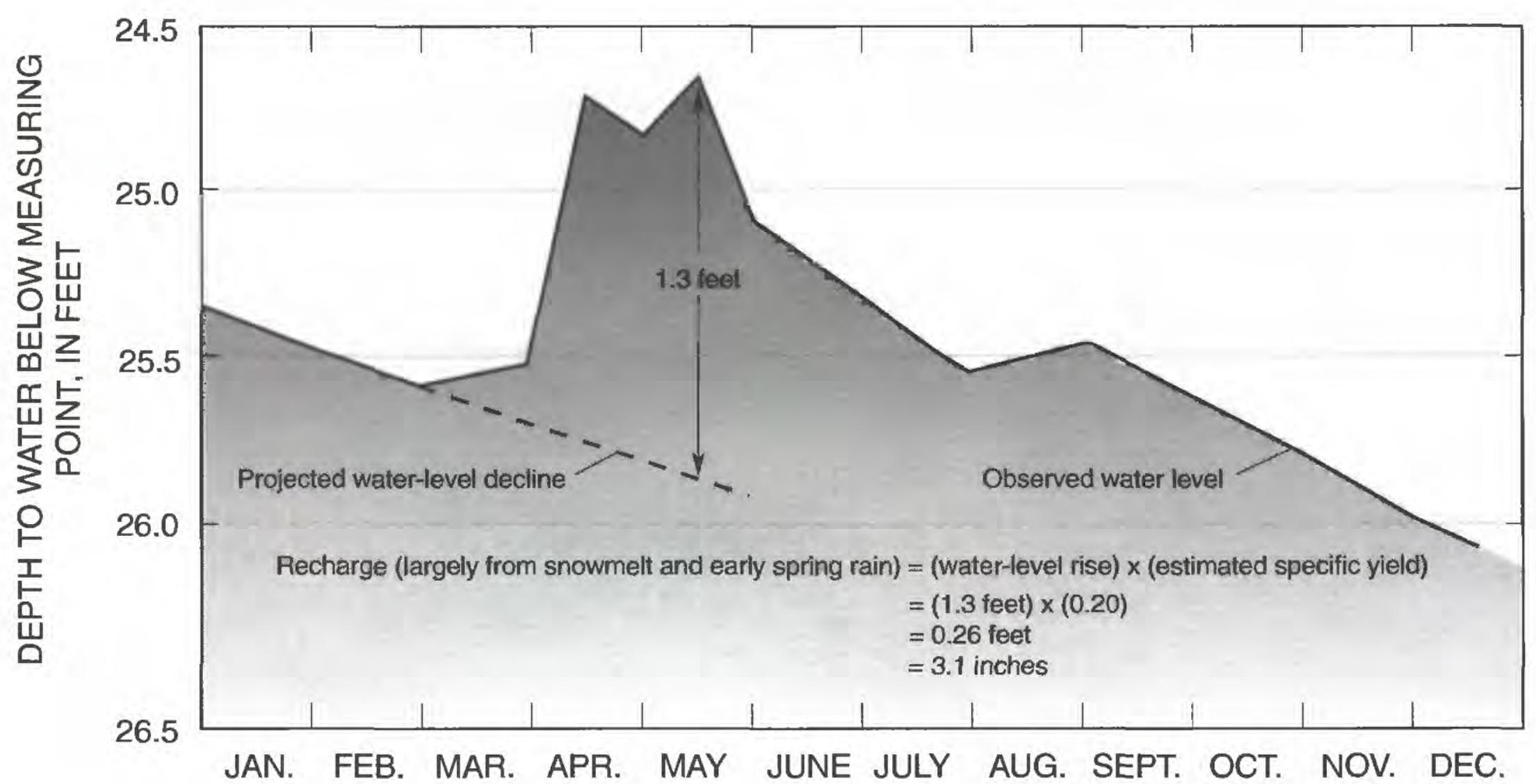

\section{Figure 21. Hypothetical hydrograph showing method of estimating recharge during spring to the unconfined aquifer.}

and Leech Lake Rivers $\left(0.4 \mathrm{ft}^{3} / \mathrm{s} / \mathrm{mi}\right)$. The measured net streamflow gain in the Boy River in 1991 was $11 \mathrm{ft}^{3} / \mathrm{s}$ in a 9.4 mile reach from above Boy Lake to above Leech Lake $\left(1.2 \mathrm{ft}^{3} / \mathrm{s} / \mathrm{mi}\right)$. The measured net streamflow gains for the Leech Lake and Boy Rivers may be partially attributable to a net change in inflow to and outflow from Mud Lake and Boy Lake, respectively. The much greater gains per mile for the Mississippi River (3.3 to $7.0 \mathrm{ft}^{3} / \mathrm{s}$ ) compared to the Leech Lake and Boy Rivers $\left(0.4\right.$ to $\left.1.2 \mathrm{ft}^{3} / \mathrm{s}\right)$ indicate that the discharge of water from the ground-water system to the river is greater for the Mississippi River than for the Leech Lake and Boy Rivers. Discharge to these rivers depends on the thickness of the riverbed material, vertical hydraulic conductivity of the riverbed material, and hydraulichead differences between the aquifer and the river. In general, ground-water discharge to rivers in the study area exceeds leakage from rivers to ground water. The Mississippi River, however, may serve as a source of water to the ground-water system in the extreme southeastern part of the study area. Streamflow measurements in 1991 indicated a net loss of $28 \mathrm{ft}^{3} / \mathrm{s}$ in a $20.1 \mathrm{mile}\left(1.4 \mathrm{ft}^{3} / \mathrm{s} / \mathrm{mi}\right)$ reach from immediately below the confluence of the Mississippi and Leech Lake Rivers to about 2 mi north of the point where the river flows out of the study area to the south.

Cass Lake, Leech Lake, and Lake Winnibigoshish primarily are ground-water discharge areas. These lakes also may be sources of recharge to the ground-water system near their outlets to the Mississippi (Cass Lake and Lake Winnibigoshish) and Leech Lake Rivers (Leech Lake). Flow of water out of the lakes into the underlying drift near their outlets may be due to the reservoir dams that raise the lake levels (and increase the vertical hydraulic gradient) near the outlets. Minipiezometer measurements conducted on Lake Winnibigoshish indicated downward vertical hydraulic gradients near the lake outlet and generally upward vertical hydraulic gradients for the rest of the lake near the shore.

\section{Ground-water evapotranspiration}

Ground water discharges by direct evaporation from the water table where the water table is at or near the land surface, such as in wetland areas. Ground water discharges by transpiration from vegetation where the water table is above the root zone or within reach of 


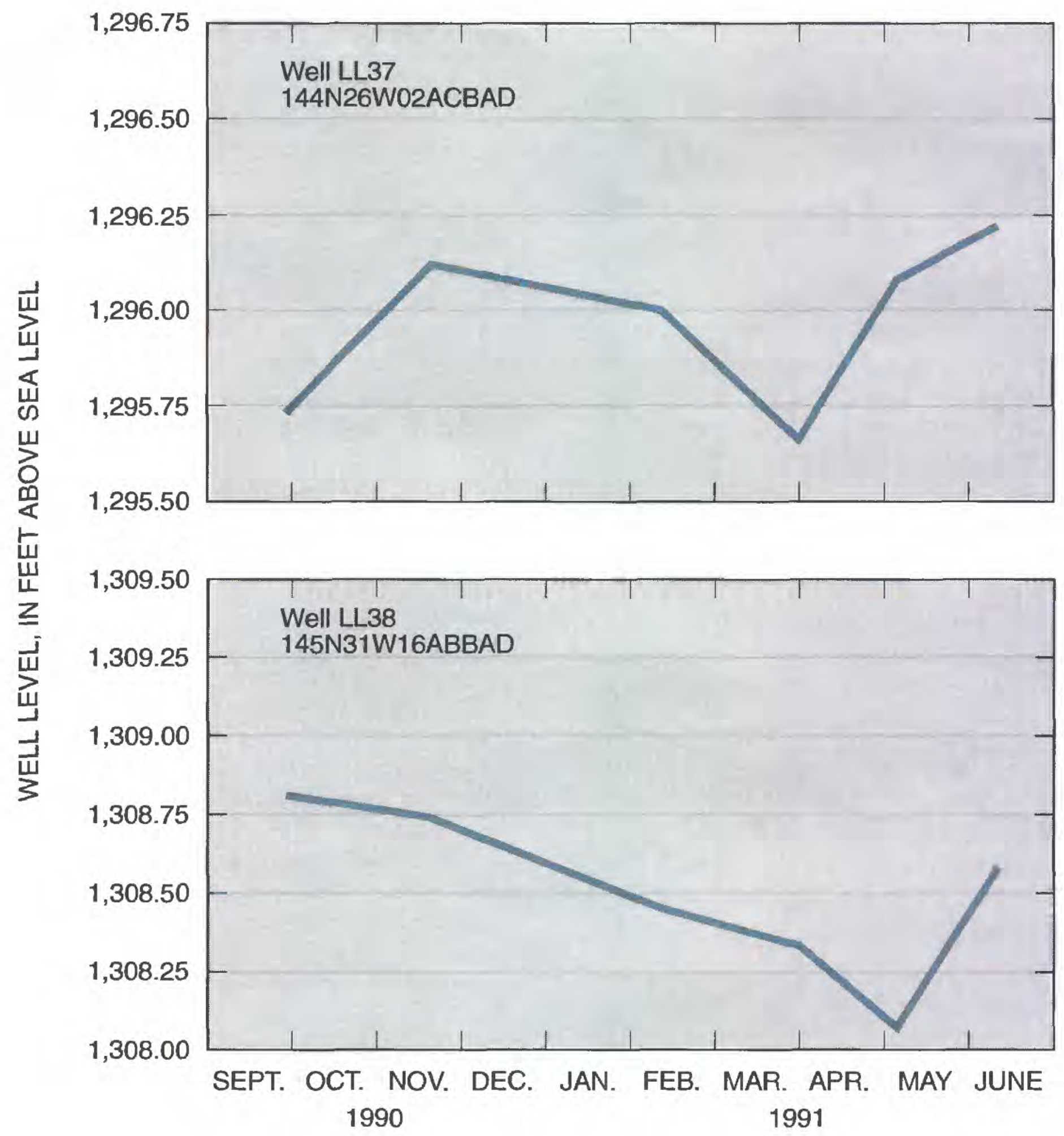

Figure 22. Water levels in wells screened in the uppermost confined aquifer, 1990-91, Leech Lake Indian Reservation, Minnesota (location of wells shown in figure 1).

roots through capillary action. Ground-water evapotranspiration is a function of the depth of the water table below land surface. As the depth to the water table increases, fewer plants have roots that extend deep enough to extract water from the water table and the evapotranspiration rate decreases. Ground-water evapotranspiration is maximum where the water table is at land surface and decreases to zero where the water table is below the root-zone depth. The maximum rootzone depth for vegetation in the study area is about 5-10 ft. The amount of ground-water loss to evapotranspiration also depends on solar energy supplied, air temperature, and humidity of the air. The rate of evapotranspiration is assumed to be a maximum of about 24 in./yr (70 percent of mean annual pan evaporation) where water levels are at land surface (Baker and others, 1979, p. 9).

Large quantities of water are discharged from the ground-water system by evapotranspiration during the summer. These losses decrease rapidly in the fall and are near zero in the winter. This seasonal variation in ground-water loss to evapotranspiration is approximately the same from year to year, provided the vegetation does not change significantly. Ground-water losses to evapotranspiration are probably greatest in the 
western and central parts of the study area where large surface-water bodies are present and depth to ground water is shallow.

\section{Ground-water withdrawals}

Ground water is withdrawn in the study area for municipal, domestic, and commercial purposes. Cass Lake (fig. 1) is the only municipality that uses ground water, with withdrawals totaling $38.8 \mathrm{Mgal}$ (million gallons) in 1989. The largest domestic user, a lodge, withdrew $0.8 \mathrm{Mgal}$ during 1989 . A paper mill reported the largest commercial use of ground water $(67.4 \mathrm{Mgal})$ in 1989. The primary use of this water was for pollution confinement. A State wayside rest area reported estimated withdrawals of $0.6 \mathrm{Mgal}$ in 1989 .

\section{Conceptual model of ground-water flow}

The general pattern of flow in the ground-water system in the study area may be summarized as follows:

(1) Water enters the ground-water system by infiltration of precipitation and underflow from the west, north, and south.

(2) The predominant regional direction of groundwater flow is to the east and southeast, generally toward the Mississippi River, with a smaller area of flow toward Leech Lake in the southern part of the study area.

(3) Water moves predominantly horizontally through the aquifers, whereas vertical components of flow are significant in confining units.

(4) Water discharges by leakage to surface-water bodies and underflow to the southeast within the Mississippi River Valley.

Ground water moves into and out of the study area primarily where confined aquifers extend beyond the boundaries of the study area. The main continuous body of the unconfined aquifer (fig. 9) does not extend beyond the boundaries of the study area, except for a narrow band along the northwestern boundary. Some underflow into the study area through the unconfined aquifer may be where isolated surficial sand units are present at the boundaries.

The general direction of ground-water flow in the unconfined aquifer is similar to the general direction of surface-water drainage. Ground-water flow in the aquifer is toward the Mississippi River and the three large lakes in the study area, Lake Winnibigoshish and Cass and Leech Lakes (fig. 23). These lakes and the Mississippi River are major discharge points for the unconfined and uppermost confined aquifers in the study area. Ground-water divides, which separate ground-water-flow systems discharging to the lakes and the Mississippi River, are approximately coincidental with surface-water (topographic) divides between the surface-water bodies. Locally, flow in the unconfined aquifer is toward numerous small streams, wetlands, and lakes and may vary significantly from the regional direction of ground-water flow shown in figure 23.

Hydraulic gradient is the change in hydraulic head per unit distance of flow and, in conjunction with hydraulic conductivity, determines the rate of movement of ground water. The horizontal hydraulic gradient in the unconfined aquifer, as inferred from the spacing of the water-table altitude contours, is about $10-20 \mathrm{ft} / \mathrm{mi}$ (feet per mile) west and east of Cass Lake, north and southeast of Lake Winnibigoshish, and near Ball Club Lake. The horizontal hydraulic gradient is less than 10 $\mathrm{ft} / \mathrm{mi}$ for the remainder of the study area. Altitude of the hydraulic head in the unconfined aquifer ranges from about 1,275 ft near Ball Club Lake to about $1,350 \mathrm{ft}$ northwest of Cass Lake and northeast of Lake Winnibigoshish.

The direction of ground-water flow in the uppermost confined aquifer is toward the Mississippi River and toward the three large lakes in the study area, Lake Winnibigoshish and Cass and Leech Lakes (figs. 24 and 25). These are the major discharge points for the aquifer in the study area. Ground water flows from the aquifer through the uppermost confining unit and then discharges to rivers and lakes. These areas of discharge are identified based on inferences made from potentiometric-surface maps. Ground-water divides, which separate ground-water flow discharging to the Mississippi River and large lakes, are approximately coincidental with surface-water (topographic) divides between the surface-water bodies. The flow of ground water in the uppermost confined aquifer is less affected by small streams, wetlands, and small lakes than the flow of water in the unconfined aquifer.

The horizontal hydraulic gradient in the uppermost confined aquifer is about $70 \mathrm{ft} / \mathrm{mi}$ in the southwestern part of the study area and $50 \mathrm{ft} / \mathrm{mi}$ near Ball Club Lake. The gradient is about $4-8 \mathrm{ft} / \mathrm{mi}$ for the rest of the area. Altitude of the hydraulic head in the aquifer ranges from about 1,280 ft near Ball Club Lake to greater than 1,400 $\mathrm{ft}$ southwest of Leech Lake. Hydraulic heads in the aquifer southeast of Ball Club Lake are above landsurface altitude and wells screened in the aquifer in this area will flow (fig. 24).

Flow in aquifers is predominantly horizontal, whereas flow in confining units has significant vertical components, due to differences in grain size and hydraulic conductivities of the materials comprising the units. The hydraulic conductivity of an aquifer is much 


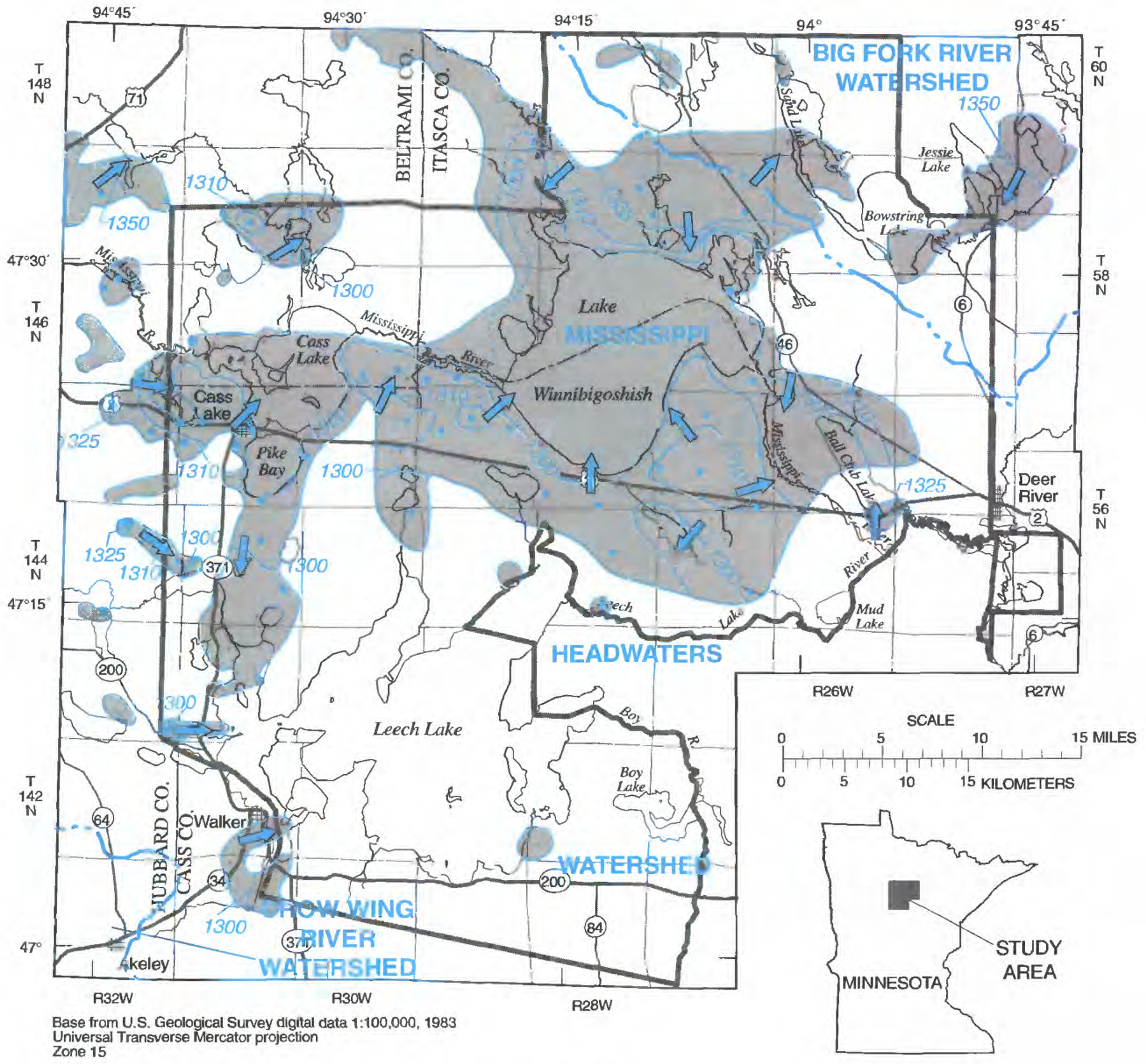

EXPLANATION

Extent of unconfined aquifer

Leech Lake Indian Reservation boundary

Watershed divide--Generally coincides with ground-water divide

- 1300 - Water table contour--Shows altitude of water table in unconfined aquifer. Interval is variable. Datum is sea level. Dashed where inferred

$\Rightarrow$ Generalized direction of ground-water flow

Well used for control

Figure 23. Altitude of water table in the unconfined aquifer. 


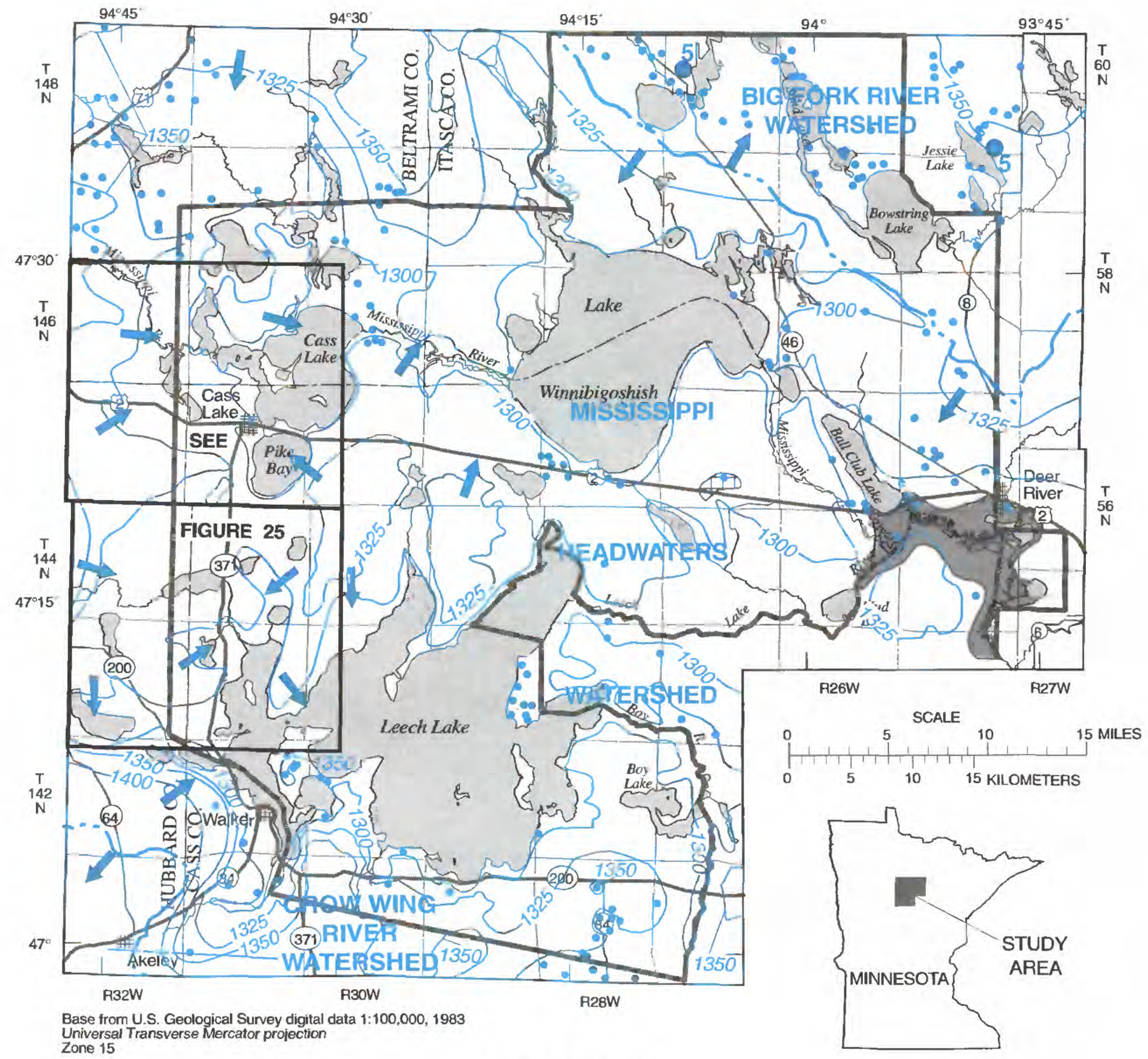

EXPLANATION

Area where potentiometric heads are above land surface

Leech Lake Indian Reservation boundary

Watershed divide--Generally coincides with ground-water divide

- 1300 - Potentiometric contour--Shows altitude at which water level would have stood in tightly cased wells open to the uppermost confined aquifer. Interval 25 feet. Datum is sea level.

$\Rightarrow$ Generalized direction of ground-water flow

Cluster of closely-spaced well sites--Number indicates number of wells in cluster

Well used for control

Figure 24. Potentiometric surface of the uppermost confined aquifer (modified from Oakes and Bidwell, 1968). 
greater than a confining unit and therefore offers less resistance to flow.

In areas underlain by both the unconfined and uppermost confined aquifers, altitudes of the potentiometric surfaces are similar, suggesting that there is little vertical leakage between the two aquifers. In highland (morainal) areas surrounding the unconfined aquifer, the water table in the till is generally higher than the potentiometric surface of the uppermost confined aquifer, suggesting a component of downward flow. Stark and others (1991, p. 35) report that in the BemidjiBagley area the water table in the till is as much as $11 \mathrm{ft}$ higher than the potentiometric surface of the uppermost confined aquifer. Near areas of discharge, such as large lakes and rivers, the potentiometric surface of the uppermost confined aquifer generally is higher than the potentiometric surface of the unconfined aquifer, suggesting a component of upward flow. The available water-level data indicates that in the Mississippi River Valley near Ball Club Lake, in the southeastern part of the study area, hydraulic heads in the uppermost confined aquifer are as much as $15 \mathrm{ft}$ higher than hydraulic heads in the unconfined aquifer. Downward leakage of water occurs in highland areas where ground water flows vertically through overlying till to the uppermost confined aquifer. Water moves vertically upward from deep to shallow aquifers in areas of regional discharge such as the Mississippi River, Cass Lake, Lake Winnibigoshish, and Leech Lake.

Horizontal and vertical directions of flow in the aquifer system may be illustrated using hydrogeologic sections and isopotential lines (figs. 8 and 26). The section is oriented along a principal ground-water flow path that represents flow from highland recharge to discharge at major lakes and the Mississippi River. Figure 8 illustrates (1) the downward vertical hydraulic gradient in highland areas, with the potentiometric surface of the unconfined aquifer being higher than that of the uppermost confined aquifer (recharge area), (2) the similar potentiometric surfaces for the unconfined and uppermost confined aquifers in lowland areas near Cass Lake and Lake Winnibigoshish (located about $1 \mathrm{mi}$ to the north of the section in the central part of the section), and (3) the relatively large upward vertical hydraulic gradient in the Mississippi River Valley in the southeastern part of the study area (near Ball Club Lake), with the potentiometric surface of the uppermost confined aquifer being higher than that of the unconfined aquifer (discharge area).

Figure 26 shows isopotential lines (lines of equal hydraulic head) and directions of flow along the hydrogeologic section. Flowpaths are perpendicular to the isopotential lines. Ground-water flow is predominantly horizontal in aquifers, whereas vertical components of flow are substantial in confining units. Vertical differences in hydraulic head within the unconfined and uppermost confined aquifers generally are small, as indicated by vertical isopotential lines, and flow is primarily horizontal. In contrast, vertical head changes within the uppermost confining unit are generally significant, with isopotential lines deviating from vertical, indicating a vertical component of flow. The vertical component would be more prominent if the vertical scale of the hydrogeologic section were not greatly exaggerated.

The flowpaths in figure 26 also illustrate discharge areas along the trace of the hydrogeologic section. Localized ground-water divides are present in the unconfined aquifer between Cass Lake and Lake Winnibigoshish (located about $1 \mathrm{mi}$ to the north of the section in the central part of the section). These localized ground-water divides in the unconfined aquifer do not significantly influence flowpaths in the uppermost confined aquifer. Ground water in the uppermost confined aquifer shown in the western part of the section discharges to Cass Lake and Lake Winnibigoshish. Ground water in the uppermost confined aquifer shown in the eastern part of the section discharges to the Mississippi River and Ball Club Lake.

\section{Ground-Water Quality}

The chemical nature of water is determined by the type and quantity of substances dissolved in it. Chemical constituents dissolved in ground water are derived mainly from materials (soil, glacial drift, and rock) through which water flows. Ground-water quality varies in response to changes in residence time, length of flow path, temperature, precipitation, and chemical reactions with minerals and aquifer materials. Groundwater quality can also be influenced by chemicals introduced to ground-water systems by human activity such as direct discharges of chemicals to the groundwater system or nonpoint sources of chemicals related to land-use activities. Chemical constituents that are present naturally in ground water can, in some instances, be the same as those introduced from human activities. Chloride is derived naturally from chloridebearing minerals but can also be introduced to groundwater systems from human and animal wastes and by leaching from de-icing chemicals. Other chemicals, particularly man-made organic chemicals such as pesticides, herbicides, and solvents, have no naturally occurring source and can be solely attributed to human activities. 


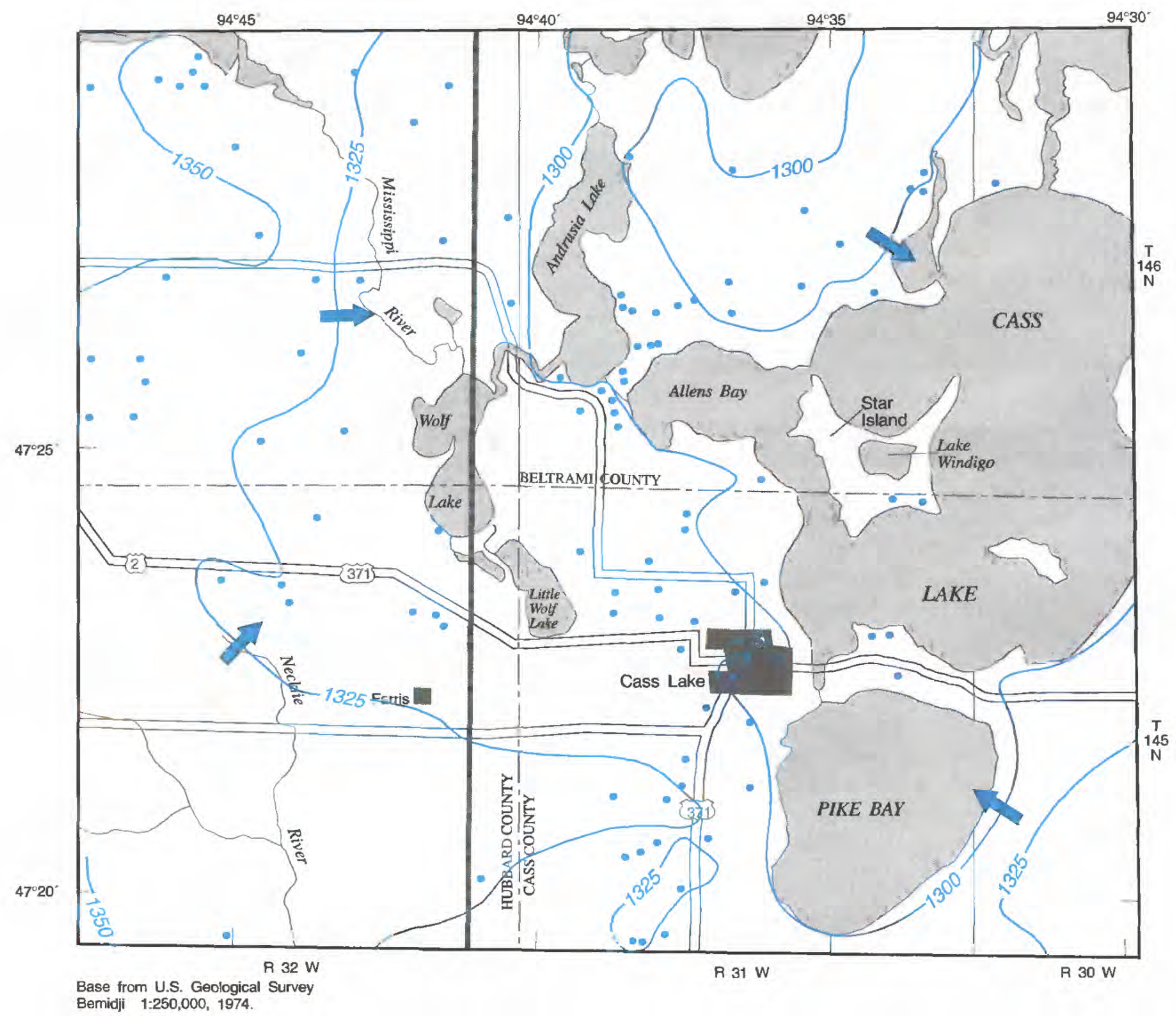

EXPLANATION

Leech Lake Indian Reservation boundary

Study Area

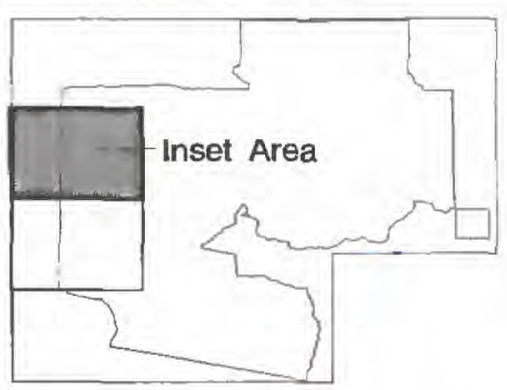

- 1300 - Potentiometric contour--Shows altitude at which water level would have stood in tightly cased wells open to the uppermost aquifer. Interval 25 feet. Datum is sea level

$\Rightarrow$ General direction of ground-water flow

- Well used for control

Figure 25. Potentiometric surface of the uppermost 


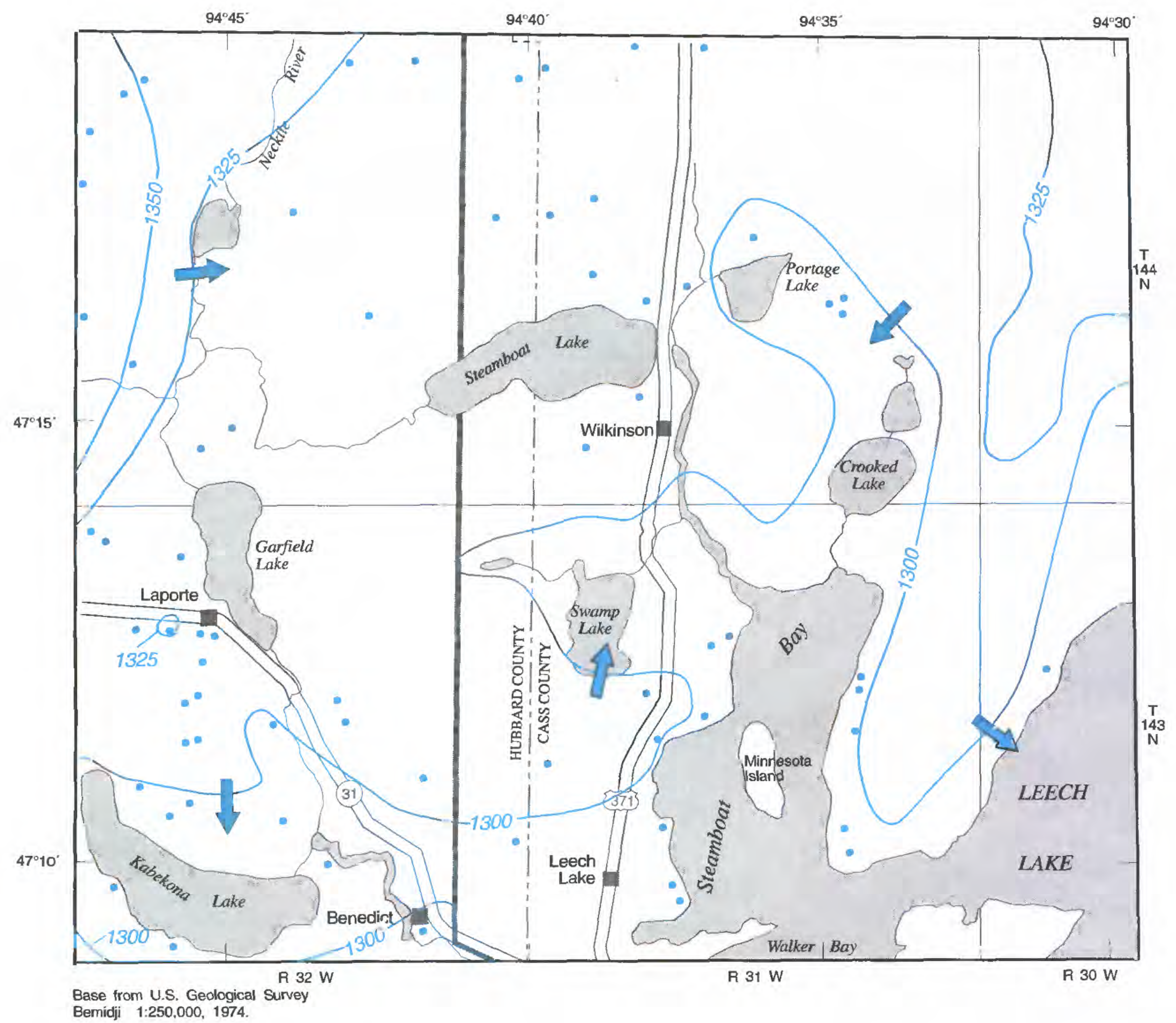

Bemidji 1:250,000, 1974.
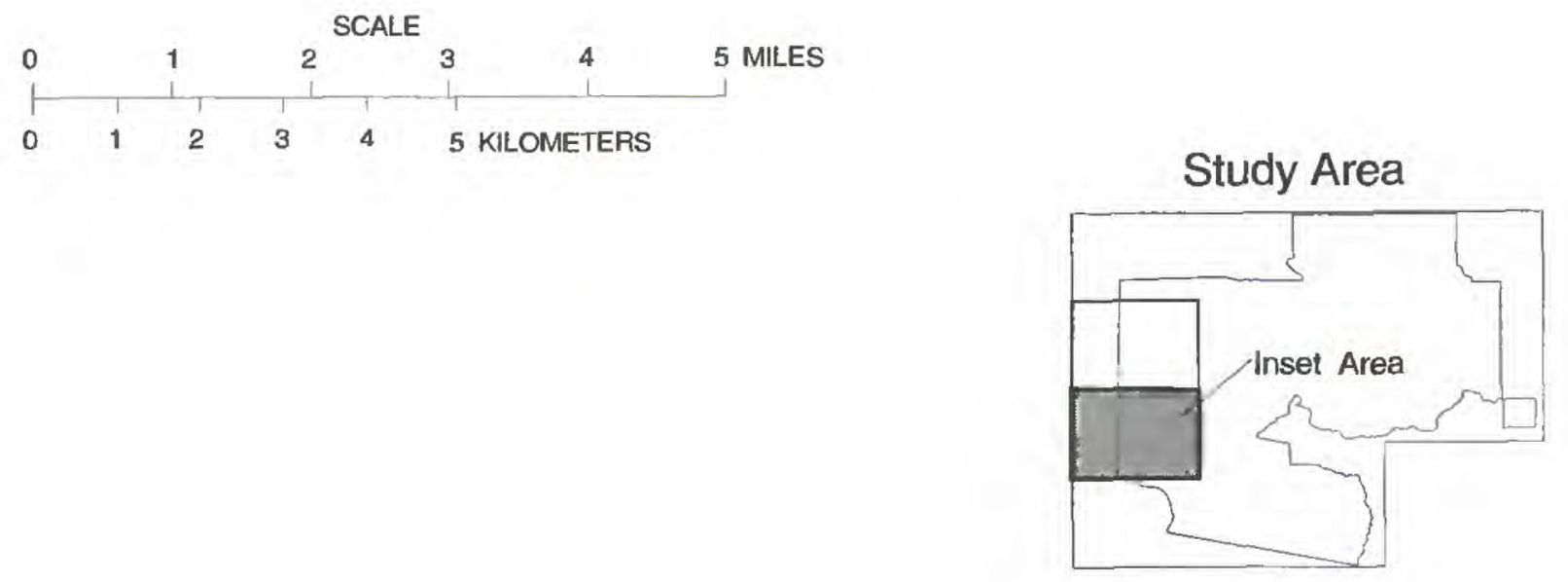

confined aquifer in the vicinity of Cass and Leech Lakes. 


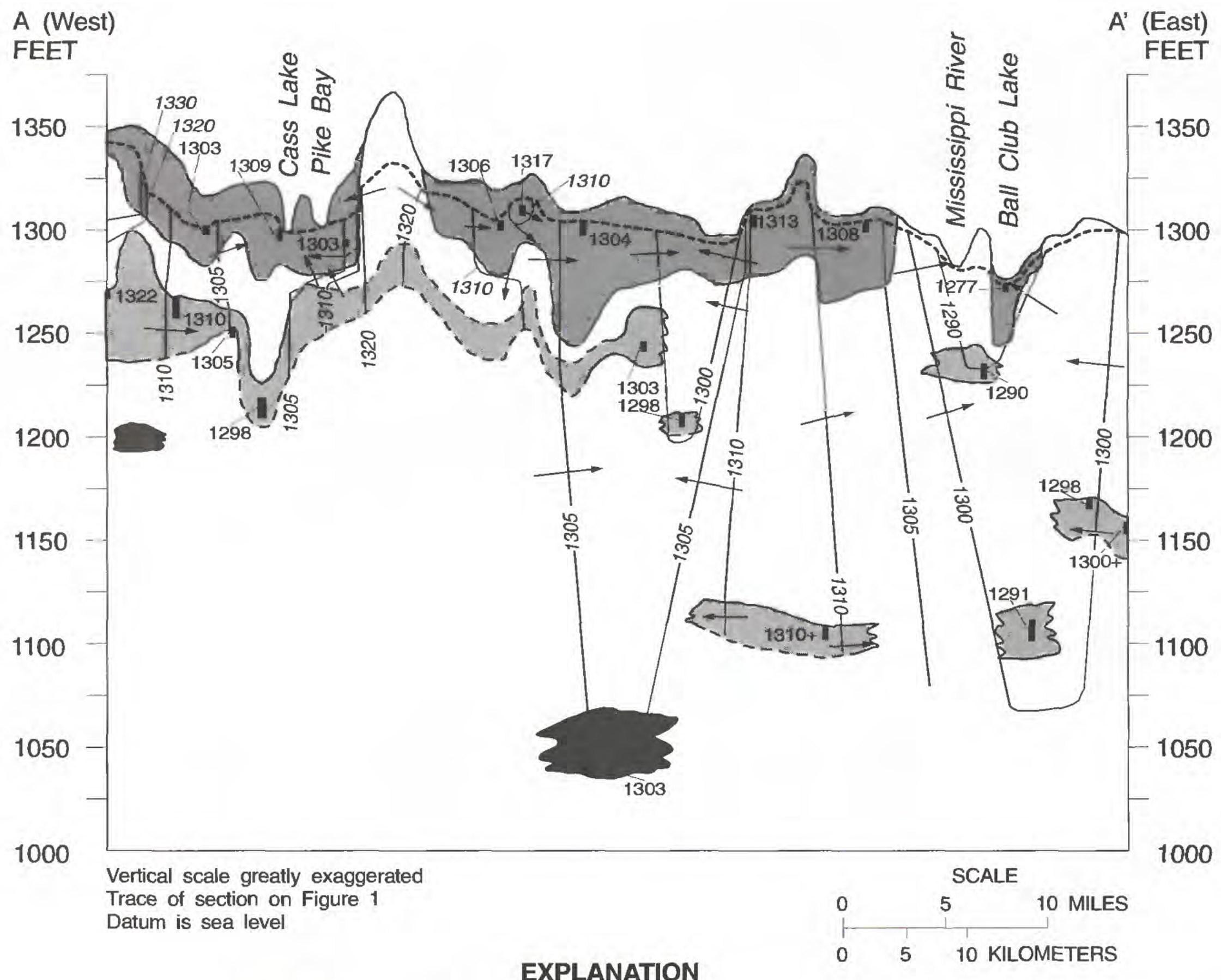

Unconfined aquifer

Uppermost confined aquifer (dashed where inferred) The uppermost confined aquifer is considered as a single hydrogeologic unit in this report. However, the aquifer probably is physically discontinuous in some areas and may consist of several aquifers separated by units of low hydraulic conductivity.

Confined aquifers below uppermost confined aquifer

Confining units, composed of clays and till

Water-table surface

$\longrightarrow$ Generalized direction of ground-water flow

1298 Well screen--Symbol shows interval open to well measured. Number is water level, in feet above sea level.

- 1300 - Isopotential line--Shows altitude at which water level would have stood in tightly cased wells. Interval, in feet, is variable.

Figure 26. Hydrogeologic section showing isopotential lines and generalized direction of ground-water flow, Leech Lake Indian Reservation, Minnesota. 
Water samples were collected from observation wells completed in the unconfined aquifer, and from domestic-supply wells completed in the uppermost confined aquifer. Ground-water samples were collected to (1) determine general ground-water quality, (2) define baseline water-quality data for use in future assessments of long-term trends, (3) determine seasonal changes in water quality, and (4) determine if ground-water quality has been affected by land-use practices.

\section{General Water Quality}

A description of the general water quality of ground water includes selected properties, major and minor ions and constituents, and nutrients (table 2). These properties and constituents affect a water's suitability for various uses.

\section{Selected properties}

Selected properties of water include specific conductance, dissolved solids, $\mathrm{pH}$, alkalinity, and hardness. Specific conductance, $\mathrm{pH}$, and alkalinity are generally determined in the field at the time a water sample is taken.

Specific conductance is a measurement of the ability of water to conduct an electric current. It is expressed in units of $\mu \mathrm{S} / \mathrm{cm}$ (microsiemens per centimeter) at $25^{\circ} \mathrm{C}$. The median specific conductance of water from the uppermost confined aquifer $(519 \mu \mathrm{S} / \mathrm{cm})$ was 40 percent greater than that of water from the unconfined aquifer $(371 \mu \mathrm{S} / \mathrm{cm})$.

Specific conductance is directly related to the concentration of dissolved solids; the greater the concentration of dissolved solids, the higher the specific conductance. High concentrations of dissolved solids in ground water can cause well-screen encrustation and reduced yields to wells. The median concentration of dissolved solids in water from the uppermost confined aquifer $(328 \mathrm{mg} / \mathrm{L})$ was 50 percent greater than that of water from the unconfined aquifer $(218 \mathrm{mg} / \mathrm{L})$.

The $\mathrm{pH}$ of a water sample is a measurement of the activity of hydrogen ions in the water and is expressed in logarithmic units. A pH of 7 is considered neutral. Water with a $\mathrm{pH}$ less than 7 is acidic; water with a $\mathrm{pH}$ greater than 7 is basic. The $\mathrm{pH}$ of distilled water is 5.6. The median $\mathrm{pH}$ of water from the unconfined and uppermost confined aquifers are similar, 7.7 and 7.6, respectively (table 2 ).

The alkalinity of water is the capacity for solutes it contains to react with and to neutralize acid. Alkalinity is produced by dissolved carbon dioxide, bicarbonate, and carbonate and is expressed in terms of an equivalent amount of calcium carbonate. The median alkalinity of water from the uppermost confined aquifer $(290 \mathrm{mg} / \mathrm{L}$ ) is 61 percent greater than that of water from the unconfined aquifer $(180 \mathrm{mg} / \mathrm{L})$.

Hardness is a poorly defined property of water. It is caused by the presence of alkaline earth elements, chiefly calcium and magnesium. Hard water inhibits the lathering of soap cleaning action and causes the formation of encrustations when water is heated. These effects are the result of the formation of insoluble compounds. Hardness is expressed in equivalent concentrations of calcium carbonate. Hardness is classified by Durfor and Becker (1964, p. 27) as: soft, $0-60 \mathrm{mg} / \mathrm{L}$; moderately hard, $61-120 \mathrm{mg} / \mathrm{L}$; hard, 121 $180 \mathrm{mg} / \mathrm{L}$; very hard, more than $180 \mathrm{mg} / \mathrm{L}$. Water from both the unconfined and uppermost confined aquifers in the study area is hard to very hard, averaging 187 and $247 \mathrm{mg} / \mathrm{L}$ as calcium carbonate, respectively.

\section{Major and minor ions and constituents}

Major ions and constituents dissolved from soil and rock make up most of the dissolved solutes in ground water; the remainder comes mostly from constituents dissolved in precipitation. Major ions in water from the unconfined aquifer, in order of decreasing concentrations (median values for the study area) are: calcium ( $54 \mathrm{mg} / \mathrm{L}$ ), silica ( $18 \mathrm{mg} / \mathrm{L}$ ), magnesium (12 $\mathrm{mg} / \mathrm{L})$, sulfate $(6.0 \mathrm{mg} / \mathrm{L})$, sodium $(3.1 \mathrm{mg} / \mathrm{L})$, potassium $(1 \mathrm{mg} / \mathrm{L})$, chloride $(0.8 \mathrm{mg} / \mathrm{L})$, and fluoride $(0.1 \mathrm{mg} / \mathrm{L})$. Major ions in water from the uppermost confined aquifer, in order of decreasing concentrations (median values for the study area) are: calcium (66 $\mathrm{mg} / \mathrm{L})$, silica (20 mg/L), magnesium $(17 \mathrm{mg} / \mathrm{L})$, sodium $(5.6 \mathrm{mg} / \mathrm{L})$, sulfate $(4.1 \mathrm{mg} / \mathrm{L})$, chloride $(3.6 \mathrm{mg} / \mathrm{L})$, potassium $(2 \mathrm{mg} / \mathrm{L})$, and fluoride $(0.3 \mathrm{mg} / \mathrm{L})$.

Metals and other trace constituents are typically present in concentrations less than $1 \mathrm{mg} / \mathrm{L}$ in natural waters. Some of these constituents, such as iron and manganese, commonly are determined when laboratory analyses are conducted and usually are present. Most of the metals and other trace constituents in natural ground water are leached from the soil or dissolved from the underlying bedrock in minute quantities by circulating ground water. Some are present in precipitation. Median concentrations of dissolved iron in water from the unconfined and uppermost confined aquifers were 30 and $860 \mu \mathrm{g} / \mathrm{L}$, respectively. Median concentrations of dissolved manganese in water from both the unconfined and uppermost confined aquifers were 110 $\mu \mathrm{g} / \mathrm{L}$. Sources of iron in well water include minerals in the bedrock such as pyroxenes, amphiboles, hematite, magnetite, and pyrite; and corrosion of iron well casings. Concentrations of iron may be elevated by bacterial activity. Sources of manganese in ground 
Table 2.--Statistical summaries of water-quality data for wells screened in the unconfined and uppermost confined aquifers, Leech Lake Indian Reservation, Minnesota

$[\mathrm{mg} / \mathrm{L}$, milligrams per liter; $\mu \mathrm{g} / \mathrm{L}$, micrograms per liter; $\mu \mathrm{S} / \mathrm{cm}$, microsiemens per centimeter at 25 degrees Celsius; --, not determined; <. less than]

\begin{tabular}{|c|c|c|c|c|c|c|}
\hline Chemical constituent or property & $\begin{array}{l}\text { Number of } \\
\text { samples }\end{array}$ & Mean & $\begin{array}{l}\text { Standard } \\
\text { deviation }\end{array}$ & $\begin{array}{l}\text { Minimum- } \\
\text { maximum }\end{array}$ & Median & $\begin{array}{c}\text { Number of } \\
\text { values less } \\
\text { than } \\
\text { reporting } \\
\text { level }\end{array}$ \\
\hline \multicolumn{7}{|c|}{ Unconfined aquifer } \\
\hline Specific conductance $(\mu \mathrm{S} / \mathrm{cm})$ & 31 & 384 & 164 & $170-180$ & 371 & \\
\hline $\begin{array}{l}\text { Dissolved solids, calculated, } \\
\text { sum of constituents (mg/L) }\end{array}$ & 31 & 227 & 94 & $102-467$ & 218 & 0 \\
\hline $\mathrm{pH}$ (standard units) & 31 & 7.7 & .4 & $7.0-8.5$ & 7.7 & 0 \\
\hline Alkalinity $\left(\mathrm{mg} / \mathrm{L}\right.$ as $\left.\mathrm{CaCO}_{3}\right)$ & 31 & 180 & 77 & $75-380$ & 180 & 0 \\
\hline Hardness $\left(\mathrm{mg} / \mathrm{L}\right.$ as $\mathrm{CaCO}_{3}$ ) & 31 & 187 & 80 & $71-400$ & 190 & 0 \\
\hline Calcium, dissolved ( $\mathrm{mg} / \mathrm{L}$ as $\mathrm{Ca}$ ) & 31 & 54 & 23 & $20-120$ & 54 & 0 \\
\hline Magnesium, dissolved ( $\mathrm{mg} / \mathrm{L}$ as $\mathrm{Mg}$ ) & 31 & 12 & 6.6 & $4.1-30$ & 12 & 0 \\
\hline Sodium, dissolved (mg/L as $\mathrm{Na}$ ) & 31 & 5.7 & 8.1 & $1.0-45$ & 3.1 & 0 \\
\hline Potassium, dissolved ( $\mathrm{mg} / \mathrm{L}$ as $\mathrm{K}$ ) & 31 & 2 & 1 & $.4-5$ & 1 & 0 \\
\hline Sulfate, dissolved ( $\mathrm{mg} / \mathrm{L}$ as $\left.\mathrm{SO}_{4}\right)$ & 31 & 6.3 & 3.9 & $1.0-17$ & 6.0 & 0 \\
\hline Chloride, dissolved (mg/L as $\mathrm{Cl}$ ) & 31 & 8.1 & 19 & $.3-94$ & .8 & 0 \\
\hline Fluoride, dissolved (mg/L as F) & 31 & .1 & .05 & $.1-.3$ & .1 & 0 \\
\hline Silica, dissolved (mg/L as $\mathrm{SiO}_{2}$ ) & 31 & 18 & 5.7 & $5.7-38$ & 18 & \\
\hline $\begin{array}{l}\text { Nitrogen, nitrite plus nitrate, dissolved } \\
(\mathrm{mg} / \mathrm{L} \text { as } \mathrm{N})\end{array}$ & 31 & .58 & .99 & $<.10-4.2$ & $<.10$ & 17 \\
\hline Nitrogen, ammonia, dissolved (mg/L as $\mathrm{N}$ ) & 31 & .08 & .16 & $<.01-.87$ & .03 & 17 \\
\hline Phosphorus, total (mg/L as P) & 31 & .11 & .22 & $<.01-1.1$ & .04 & 17 \\
\hline Phosphorus, ortho dissolved, (mg/L as P) & 31 & .07 & .20 & $<.01-1.1$ & .02 & 17 \\
\hline Boron, dissolved ( $\mu \mathrm{g} / \mathrm{L}$ as $\mathrm{B})$ & 31 & 20 & 20 & $<10 .-100$ & 10 & 12 \\
\hline Iron, dissolved ( $\mu \mathrm{g} / \mathrm{L}$ as $\mathrm{Fe})$ & 31 & 1,200 & 3,800 & $6.0-20,000$ & 30 & 12 \\
\hline Manganese, dissolved ( $\mu \mathrm{g} / \mathrm{L}$ as $\mathrm{Mn})$ & 31 & 250 & 510 & $<1.0-2,800$ & 110 & 12 \\
\hline Carbon, organic dissolved (mg/L as C) & 31 & 4.1 & 6.7 & $.6-38$ & 2.1 & 12 \\
\hline
\end{tabular}

water include minerals in the bedrock, such as biotite and hornblende, and bioaccumulation by plants.

Calcium and bicarbonate are the predominant ions in water from both the unconfined and uppermost confined aquifers. A common graphical technique for presenting water-chemistry data is a Piper diagram. These diagrams permit the representation of common cation and anion compositions (based on milliequivalent-per liter concentrations) of many samples on a single graph. Figure 27 contains Piper diagrams indicating the chemistry of water from wells completed in the unconfined and uppermost confined aquifers. The points representing cation and anion data on the lower triangles are extended to the parallelogram (Freeze and
Cherry, 1979) to show the general type of water indicated by concentrations of cations and anions. Waters in the study area generally are of the calcium bicarbonate type. Calcium and bicarbonate are derived primarily from soil and rock weathering ( $\mathrm{Hem}, 1985)$.

The chemistries of water from the unconfined and from the uppermost confined aquifers are generally similar. Figure 27 shows that common cations and anions plot in the same general areas of the diagram for both aquifers. This similar grouping of data shows that the relative concentrations of major cations and anions in water samples from the unconfined and uppermost confined aquifers are similar, indicating that mixing of water between the aquifers probably occurs. 
Table 2.--Statistical summaries of water-quality data for wells screened in the unconfined and uppermost confined aquifers, Leech Lake Indian Reservation, Minnesota--Continued

\begin{tabular}{|c|c|c|c|c|c|c|}
\hline Chemical constituent or property & $\begin{array}{c}\text { Number of } \\
\text { samples }\end{array}$ & Mean & $\begin{array}{l}\text { Standard } \\
\text { deviation }\end{array}$ & $\begin{array}{l}\text { Minimum- } \\
\text { maximum }\end{array}$ & Median & $\begin{array}{c}\text { Number of } \\
\text { values less } \\
\text { than } \\
\text { reporting } \\
\text { level }\end{array}$ \\
\hline \multicolumn{7}{|c|}{ Uppermost confined aquifer } \\
\hline Specific conductance $(\mu \mathrm{S} / \mathrm{cm})$ & 17 & 503 & 110 & $351-637$ & 519 & 0 \\
\hline $\begin{array}{l}\text { Dissolved solids, calculated, } \\
\text { sum of constituents (mg/L) }\end{array}$ & 17 & 313 & 60 & $210-403$ & 328 & 0 \\
\hline $\mathrm{pH}$ (standard units) & 17 & -- & .2 & 7.4-8.0 & 7.6 & 0 \\
\hline Alkalinity $\left(\mathrm{mg} / \mathrm{L}\right.$ as $\left.\mathrm{CaCO}_{3}\right)$ & 17 & 270 & 66 & $180-380$ & 290 & 0 \\
\hline Hardness (mg/L as $\mathrm{CaCO}_{3}$ ) & 17 & 247 & 79 & $140-370$ & 230 & 0 \\
\hline Calcium, dissolved ( $\mathrm{mg} / \mathrm{L}$ as $\mathrm{Ca}$ ) & 17 & 66 & 20 & $37-95$ & 66 & 0 \\
\hline Magnesium, dissolved ( $\mathrm{mg} / \mathrm{L}$ as $\mathrm{Mg}$ ) & 17 & 20 & 7.9 & $11-40$ & 17 & 0 \\
\hline Sodium, dissolved ( $\mathrm{mg} / \mathrm{L}$ as $\mathrm{Na})$ & 17 & 14 & 17 & $2.6-54$ & 5.6 & 0 \\
\hline Potassium, dissolved ( $\mathrm{mg} / \mathrm{L}$ as $\mathrm{K}$ ) & 17 & 2.2 & .8 & $1-4$ & 2 & 0 \\
\hline Sulfate, dissolved ( $\mathrm{mg} / \mathrm{L}$ as $\left.\mathrm{SO}_{4}\right)$ & 17 & 5.0 & 4.3 & $1.0-14$ & 4.1 & 0 \\
\hline Chloride, dissolved (mg/L as $\mathrm{Cl}$ ) & 17 & 4.5 & 3.2 & $1.3-14$ & 3.6 & 0 \\
\hline Fluoride, dissolved ( $\mathrm{mg} / \mathrm{L}$ as $\mathrm{F}$ ) & 17 & .3 & .1 & $.1-.6$ & .3 & 1 \\
\hline Silica, dissolved (mg/L as $\left.\mathrm{SiO}_{2}\right)$ & 17 & 20 & 3.8 & $12-27$ & 20 & 0 \\
\hline $\begin{array}{l}\text { Nitrogen, nitrite plus nitrate, dissolved } \\
(\mathrm{mg} / \mathrm{L} \text { as } \mathrm{N})\end{array}$ & 17 & .12 & .05 & $<.10-.30$ & $<.10$ & 15 \\
\hline Nitrogen, ammonia, dissolved (mg/L as $\mathrm{N}$ ) & 17 & .24 & .19 & $<.01-.77$ & .20 & 0 \\
\hline Phosphorus, total (mg/L as $\mathrm{P})$ & 17 & .07 & .08 & $<.01-.31$ & .02 & 2 \\
\hline Phosphorus, ortho dissolved, (mg/L as P) & 17 & .05 & .07 & $<.01-.31$ & .02 & 4 \\
\hline Boron, dissolved ( $\mu \mathrm{g} / \mathrm{L}$ as $\mathrm{B})$ & 17 & 43 & 44 & $<10-140$ & 20 & 0 \\
\hline Iron, dissolved ( $\mu \mathrm{g} / \mathrm{L}$ as $\mathrm{Fe})$ & 17 & 1,100 & 940 & $20-3,700$ & 860 & 0 \\
\hline Manganese, dissolved ( $\mu \mathrm{g} / \mathrm{L}$ as $\mathrm{Mn})$ & 17 & 140 & 100 & $20-410$ & 110 & 0 \\
\hline Carbon, organic dissolved (mg/L as $\mathrm{C}$ ) & 17 & 3.1 & 2.1 & $1.3-8.6$ & 2.5 & 0 \\
\hline
\end{tabular}

Differences in the mean concentrations of constituents in waters from the two aquifers vary. The mean concentrations of selected constituents were calculated for 31 wells screened in the unconfined aquifer and for 17 wells screened in the uppermost confined aquifer (table 2). The mean concentrations of dissolved organic carbon, sulfate, and dissolved iron were greater for water from the unconfined aquifer than for water from the uppermost confined aquifer. The mean concentrations of chloride and manganese for water from the unconfined aquifer were nearly double those for water from the uppermost confined aquifer. Most chloride in ground water is dissolved from natural sources. Elevated concentrations of chloride are caused by anthropogenic effects, such as input from highway de-icing salt, fertilizers, and septic systems.

Conversely, the mean concentrations of calcium, potassium, and silica were greater for water from the uppermost confined aquifer than for water from the unconfined aquifer. The mean specific conductance and mean concentrations of alkalinity, dissolved solids, and hardness for water from the uppermost confined aquifer were 31 to 50 percent higher than for water from the unconfined aquifer. The mean concentrations of sodium, fluoride, and boron for water from the uppermost confined aquifer were 2 to 3 times greater than for water from the unconfined aquifer. 


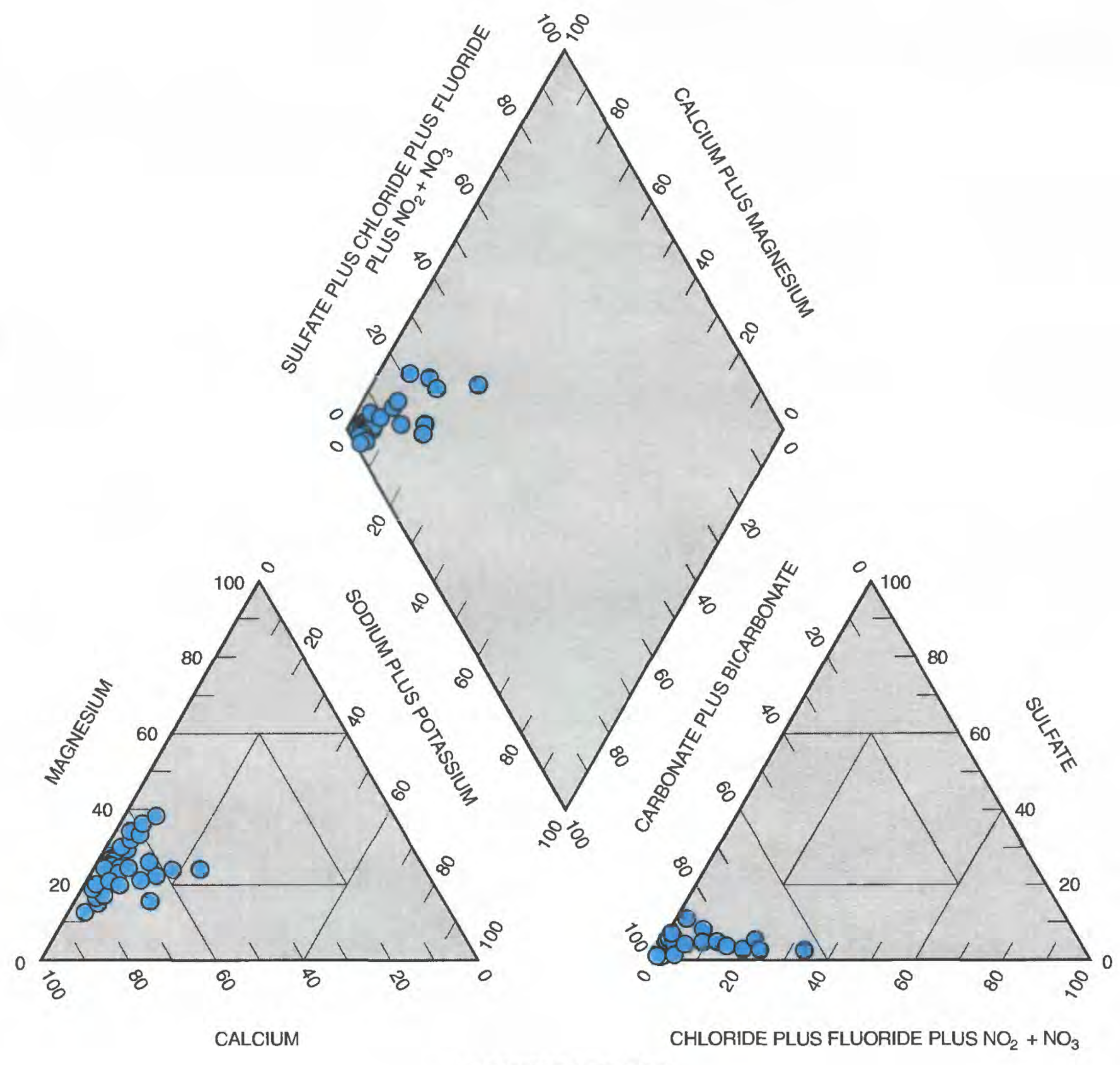

UNCONFINED AQUIFER

Figure 27. Chemical characteristics of water in the unconfined and

These higher concentrations of naturally occurring constituents in waters from the uppermost confined aquifer may occur because of the longer flow paths and longer residence times of water in the confined aquifer as compared to the unconfined aquifer. Longer residence times in the uppermost confined aquifer compared to the unconfined aquifer may reflect (1) the probable discontinuity of the confined aquifer and the low ground-water-flow velocities produced by that discontinuity, and (2) the greater depth of burial that results in longer flow paths. The combined effect is to increase the water-mineral contact time, thereby increasing mineral dissolution and the concentrations of chemical constituents in the ground water.

Differences in the chemical characteristics of waters from the unconfined and uppermost confined aquifers 


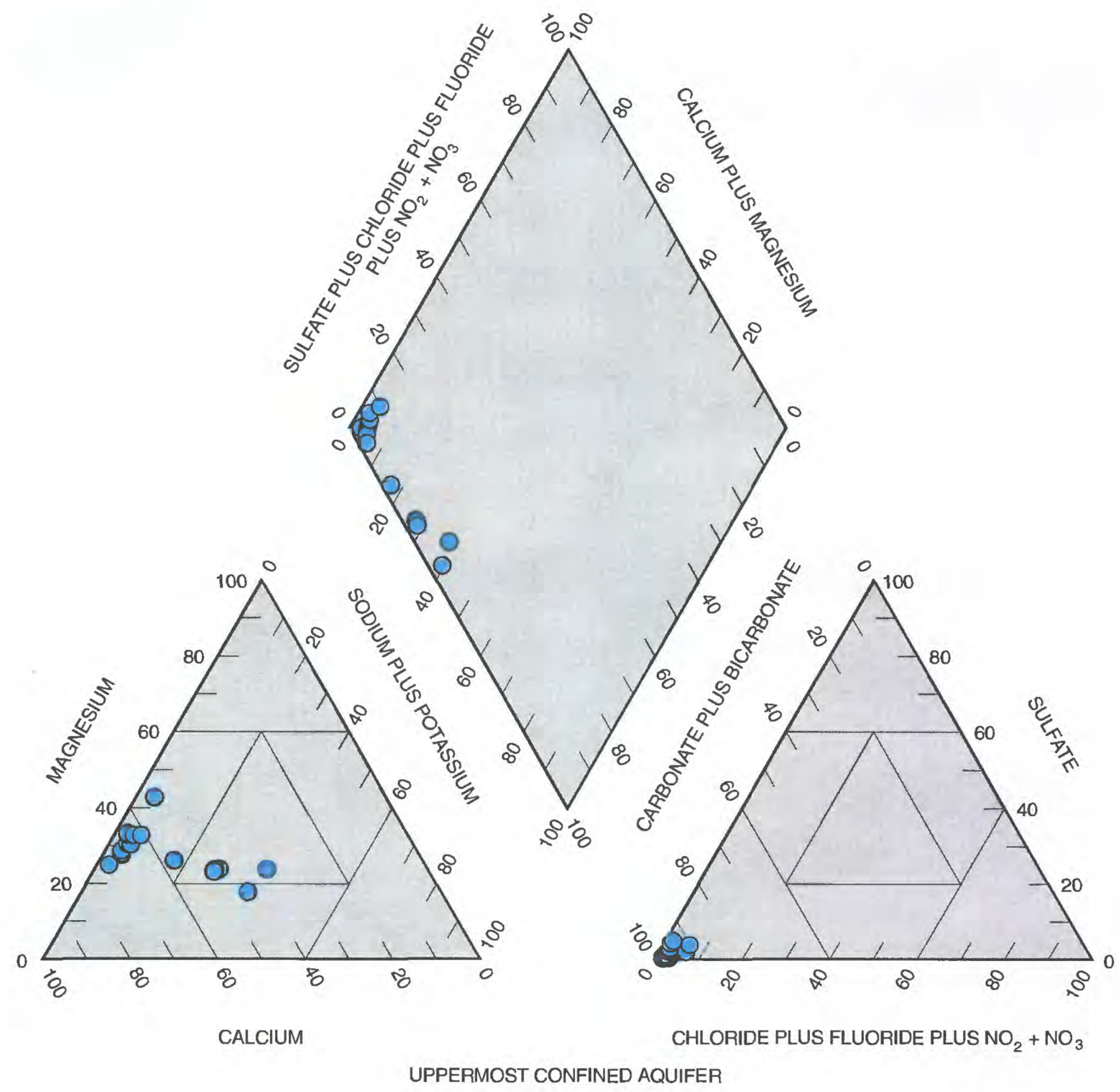

uppermost confined aquifers, Leech Lake Indian Reservation, Minnesota.

can be further illustrated by boxplots (figs. 28-31). A boxplot is a graphical method used to display summary statistics for the distribution of concentrations for a constituent. The ends of the box define the range of the middle 50 percent of the data, or that part of the data between the 25 th and 75 th percentiles. The median value of the data, the 50th percentile, is defined by the line across the box. The vertical lines beyond each end of the box are called whiskers, and show the range of those data that extend 1.5 times the range between the 25 th and 75 th percentiles beyond the ends of the box; the whiskers terminate at the maximum and minimum adjacent values. Data points beyond the whiskers are called outliers because their values differ greatly from the rest of the data. The greater median concentrations of dissolved solids, specific conductance, hardness, and alkalinity in water from the uppermost confined aquifer compared to water from the unconfined aquifer are 

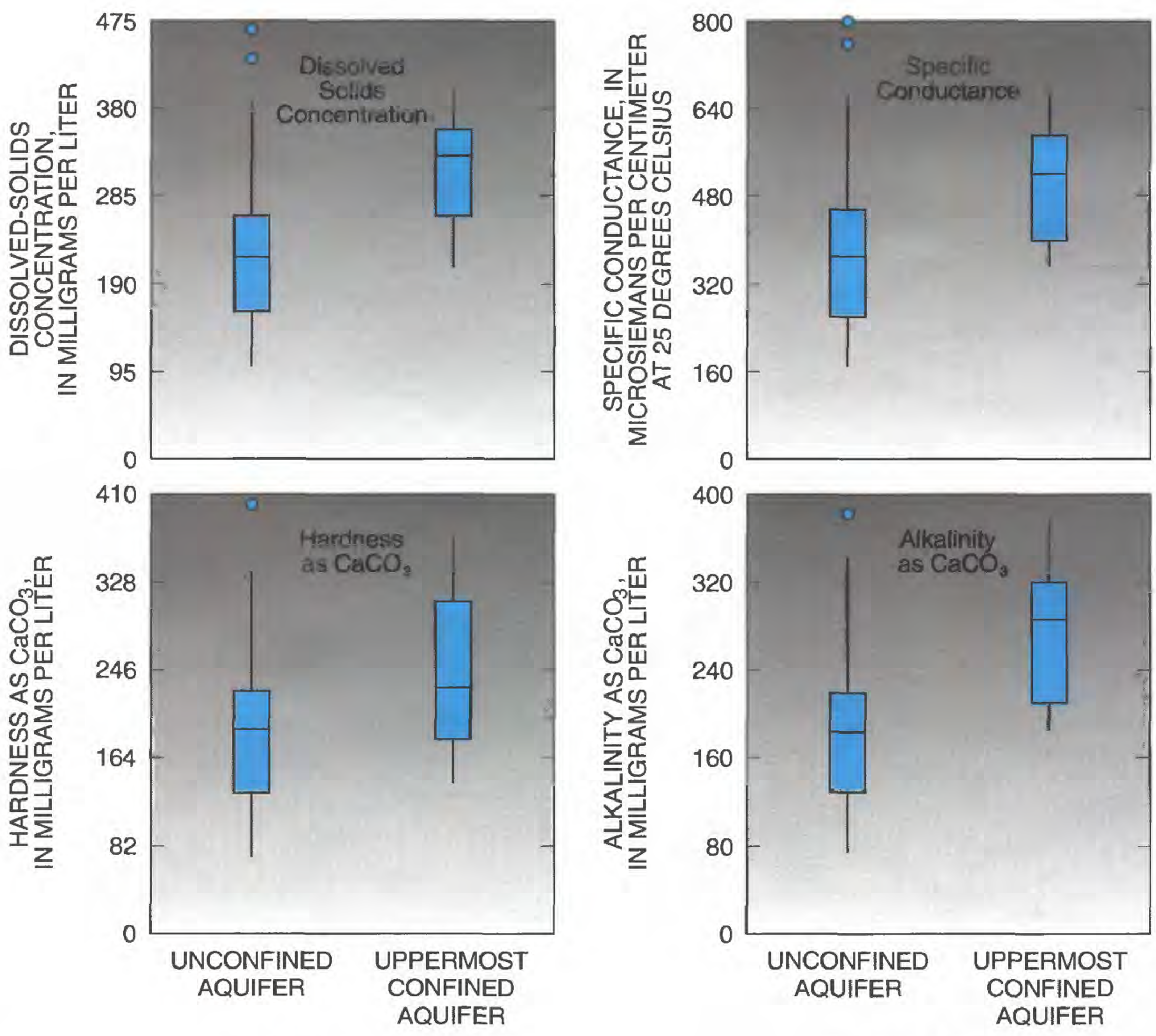

SOURCE OF WATER

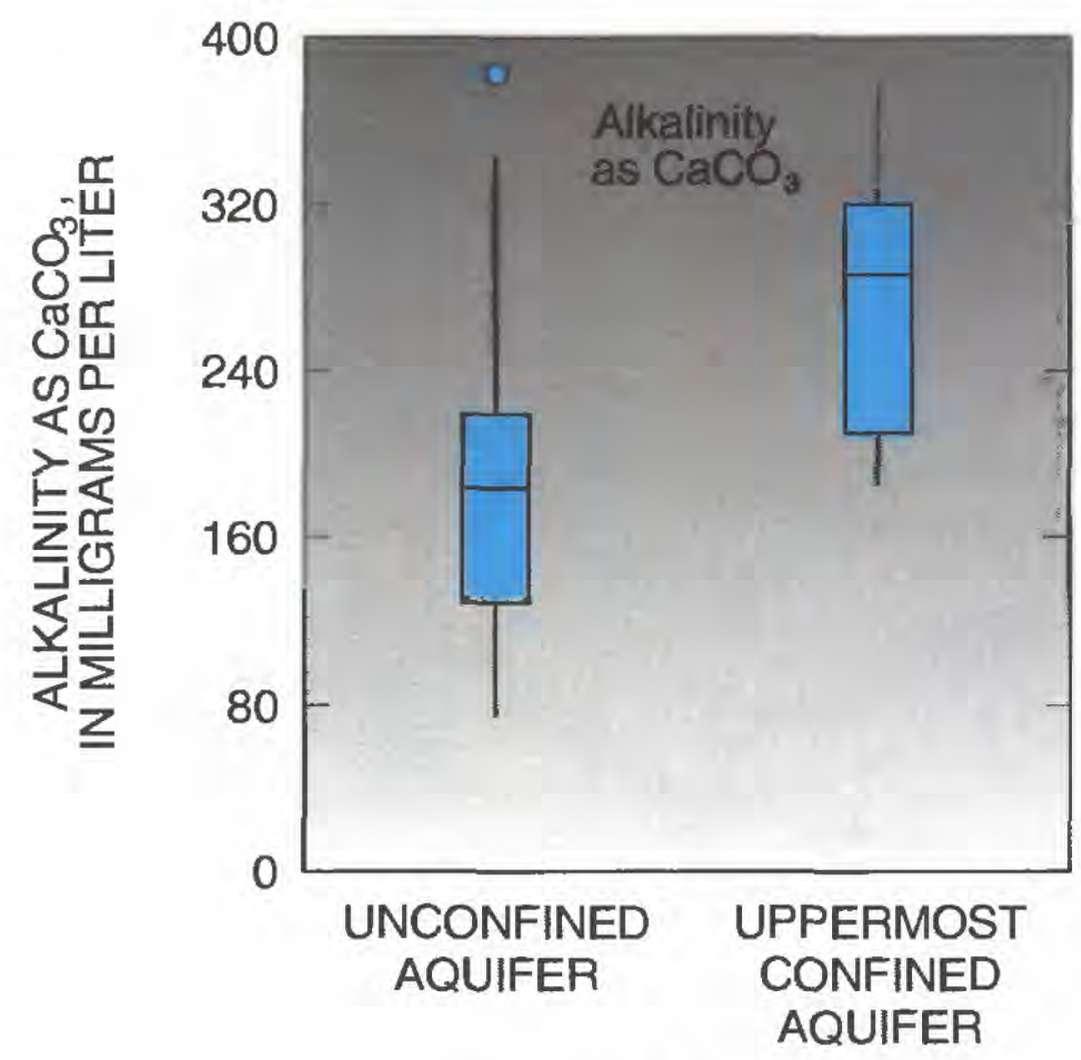

SOURCE OF WATER

\section{EXPLANATION}

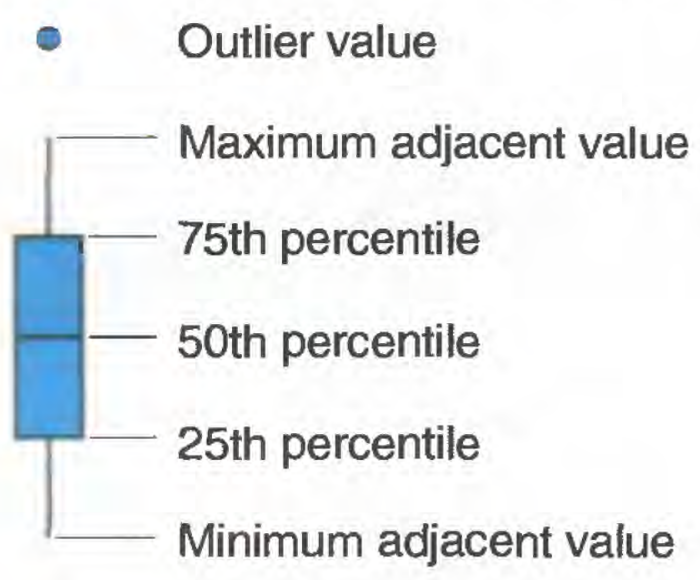

Percentile-Percentage of analyses equal to or less than indicated values.

See page 49 for explanation of maximum and minimum adjacent value

Figure 28. Concentrations of dissolved solids, specific conductance, hardness, and alkalinity in water from the unconfined and uppermost confined aquifers, Leech Lake Indian Reservation, Minnesota. 

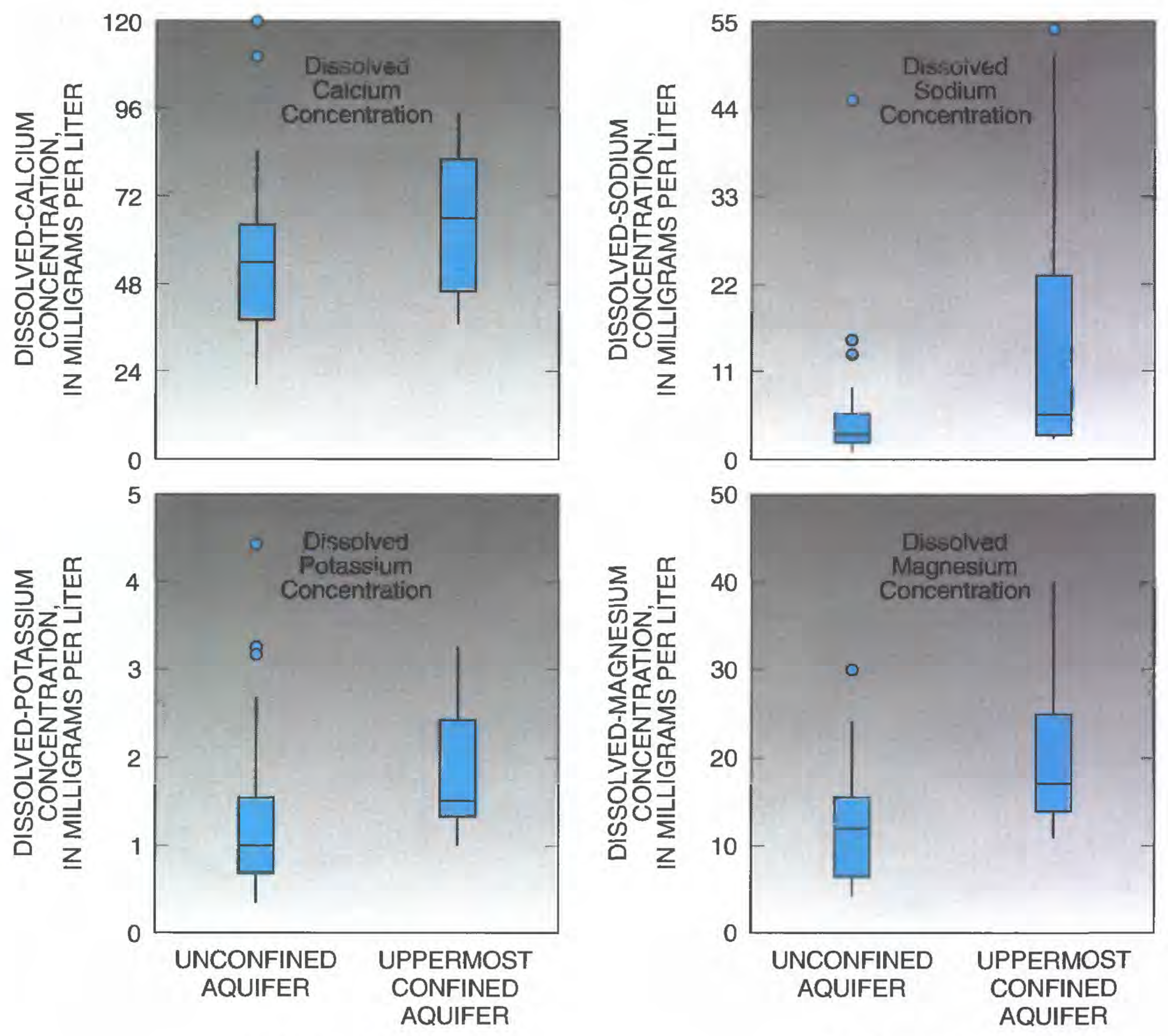

SOURCE OF WATER

SOURCE OF WATER

\section{EXPLANATION}

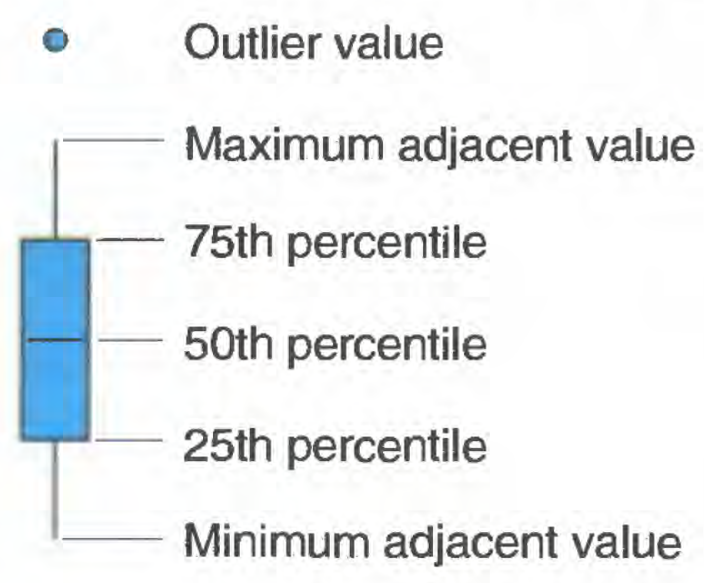

Percentile-Percentage of analyses equal to or less than indicated values.

See page 49 for explanation of maximum and minimum adjacent value

Figure 29. Concentrations of dissolved calcium, dissolved sodium, dissolved potassium, and dissolved magnesium in water from the unconfined and uppermost confined aquifers, Leech Lake Indian Reservation, Minnesota. 

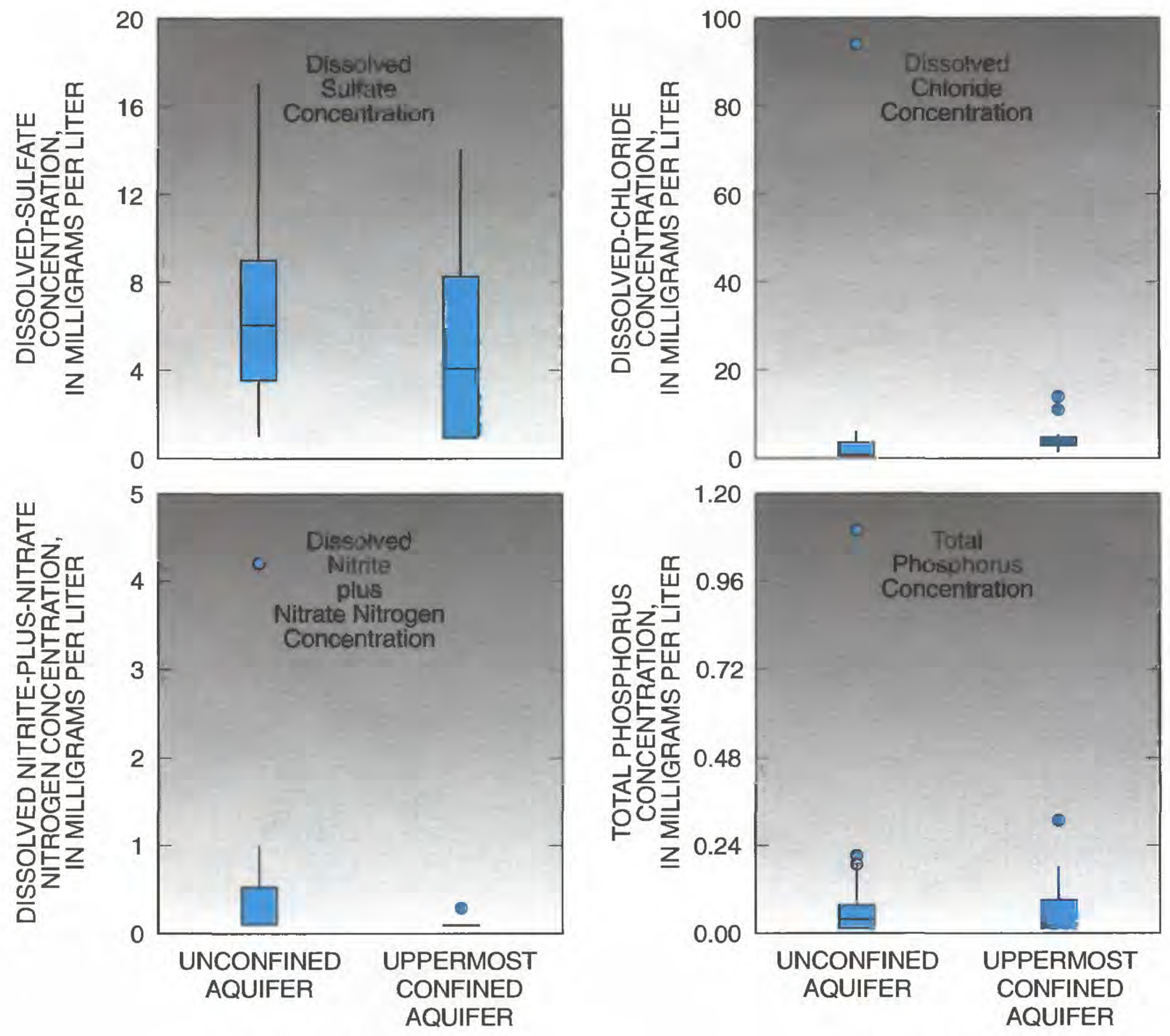

SOURCE OF WATER

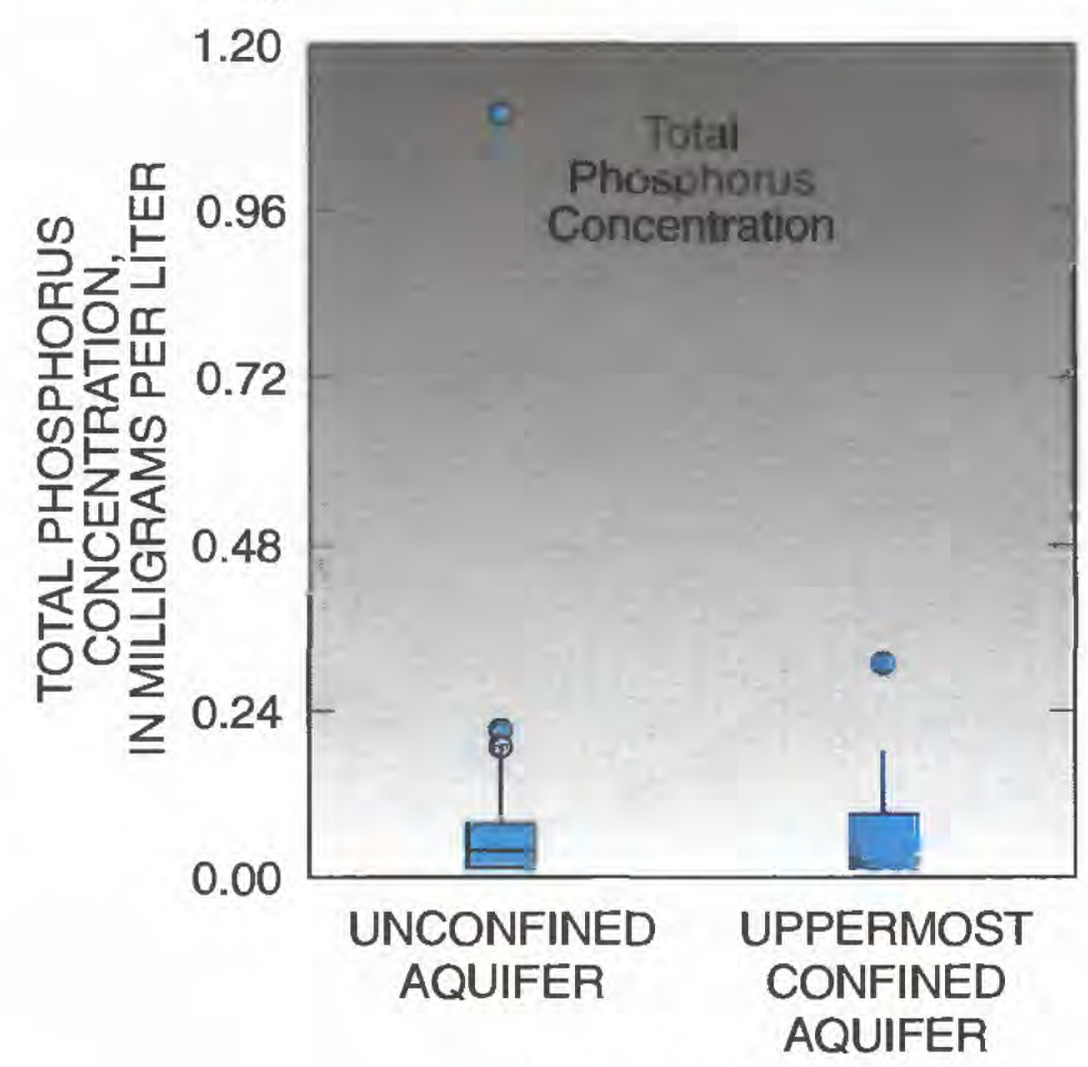

SOURCE OF WATER

\section{EXPLANATION}

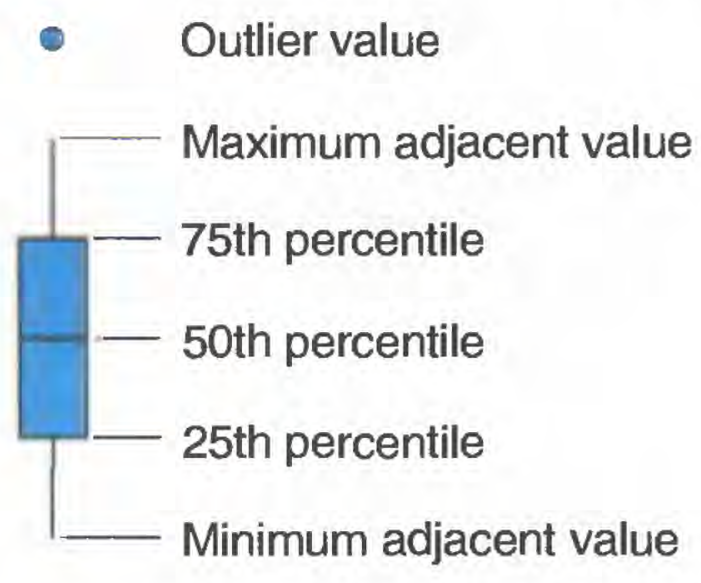

Percentile-Percentage of analyses equal to or less than indicated values.

See page 49 for explanation of maximum and minimum adjacent value

Figure 30. Concentrations of dissolved sulfate, dissolved chloride, dissolved nitrite plus nitrate nitrogen, and total phosphorus in water from the unconfined and uppermost confined aquifers, Leech Lake Indian Reservation, Minnesota. 

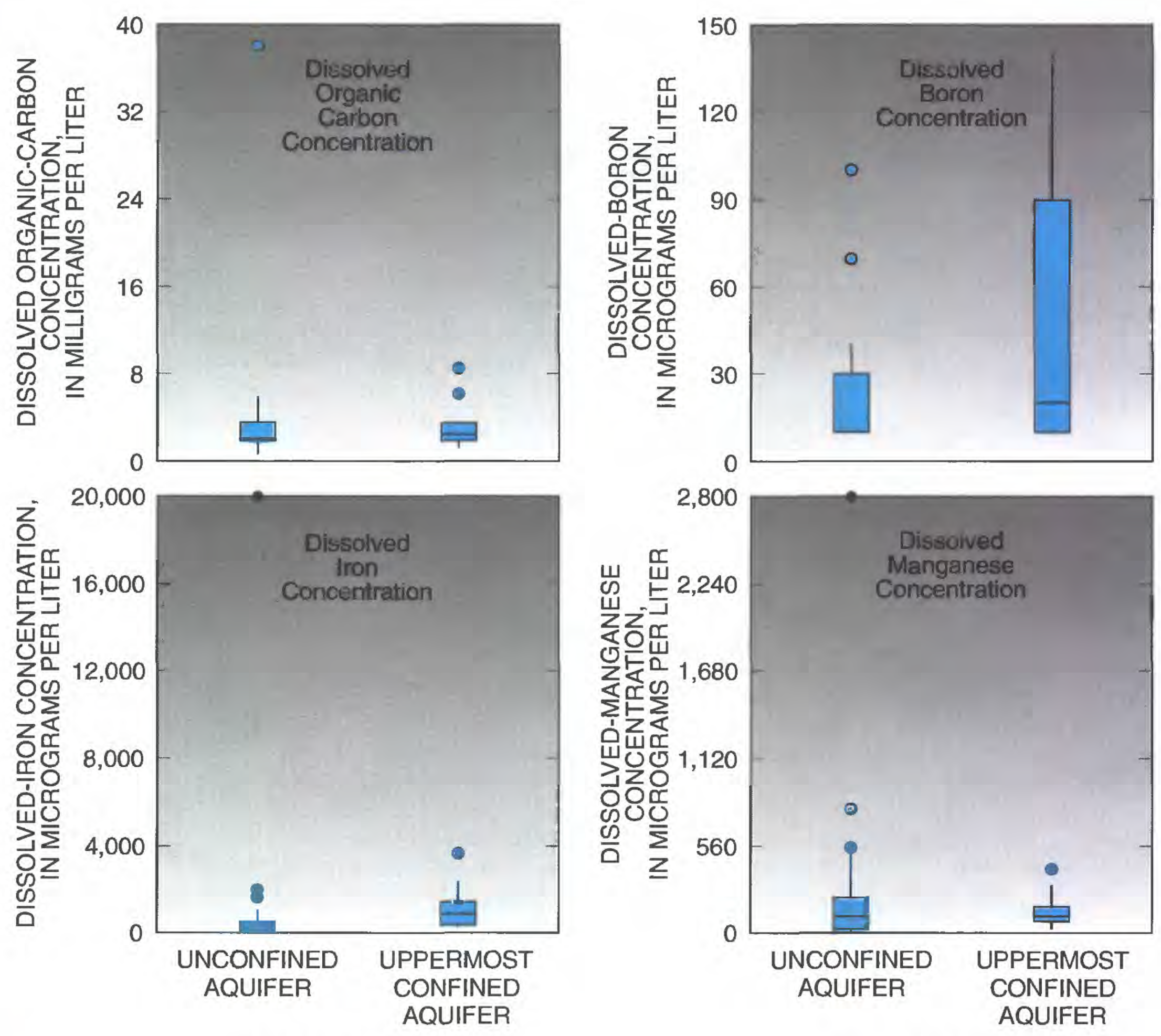

SOURCE OF WATER

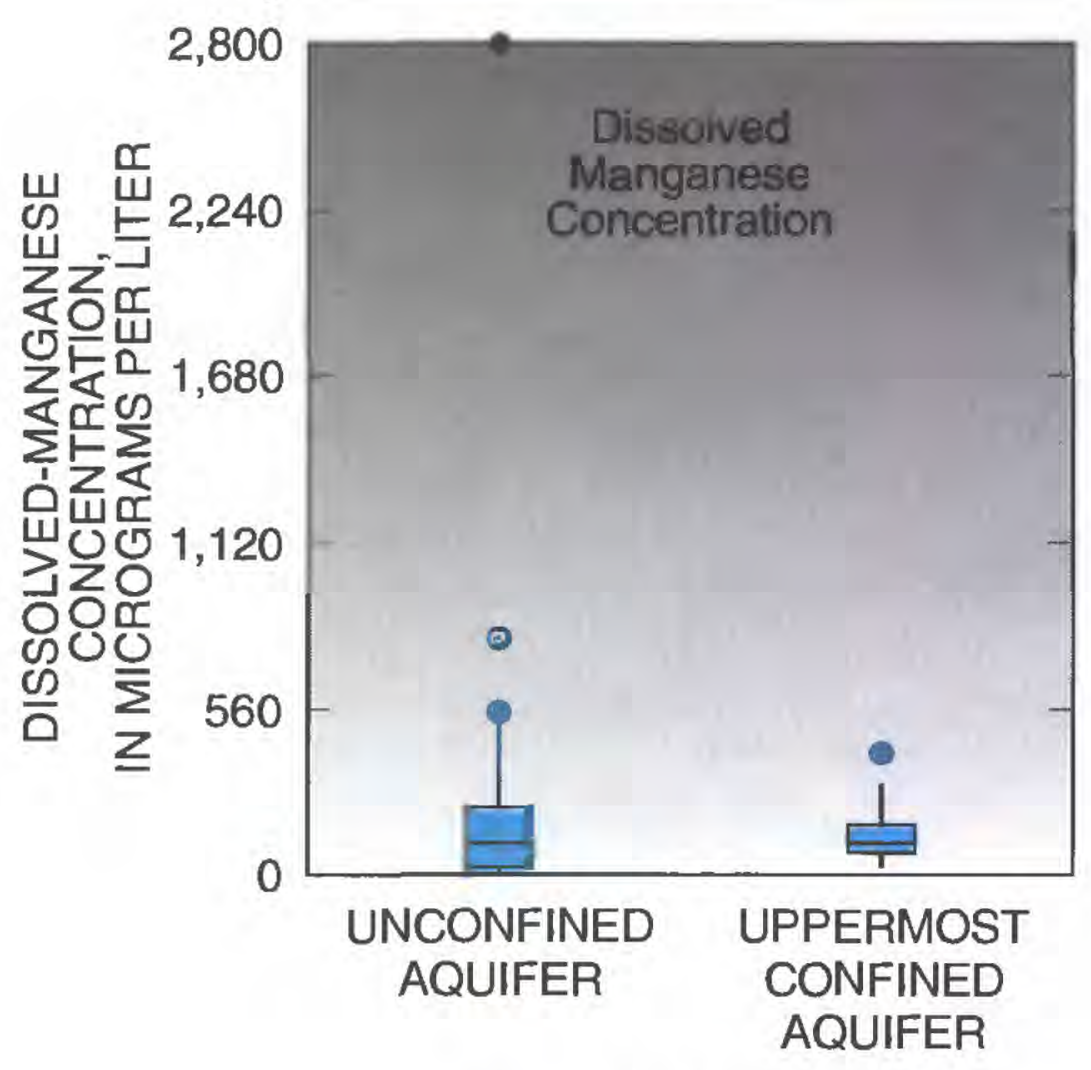

SOURCE OF WATER

\section{EXPLANATION}

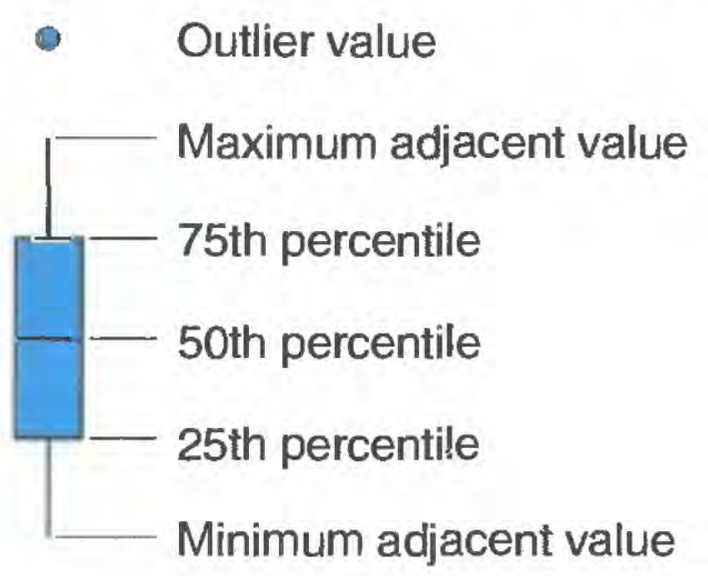

Percentile-Percentage of analyses equal to or less than indicated values.

See page 49 for explanation of maximum and minimum adjacent value

Figure 31. Concentrations of dissolved organic carbon, dissolved boron, dissolved iron, and dissolved manganese in water from the unconfined and uppermost confined aquifers, Leech Lake Indian Reservation, Minnesota. 
illustrated in figure 28. Figure 29 illustrates the greater median concentrations of calcium, sodium, potassium, and magnesium in water from the uppermost confined aquifer compared to water from the unconfined aquifer. The median concentrations of sulfate and total phosphorus in water from the unconfined aquifer are greater than those in water from the uppermost confined aquifer (fig. 30). The median concentration of chloride in water from the uppermost confined aquifer is greater than in water from the unconfined aquifer, but the maximum concentration is greater in water from the unconfined aquifer (fig. 30). The variability in concentrations of nitrite plus nitrate nitrogen and the magnitude of larger values is much greater for water from the unconfined aquifer compared to water from the uppermost confined aquifer (fig. 30 ). The relatively high concentrations of chloride and nitrite plus nitrate nitrogen in water from the unconfined aquifer represented by the larger values are probably caused by human activities at land surface. Human activities at land surface include salting road surfaces (source of chloride) and applying fertilizers (source of nitrite plus nitrate nitrogen). The variability in concentrations of boron is much greater for water from the uppermost confined aquifer than for water from the unconfined aquifer (fig. 31). The magnitude of larger values for concentrations of dissolved organic carbon, iron, and manganese is much greater for water from the unconfined aquifer than for water from the uppermost confined aquifer (fig. 31 ).

The U.S. Environmental Protection Agency (USEPA) has set maximum contaminant levels (MCLs) and secondary maximum contaminant levels (SMCLs) for some constituents in drinking water (USEPA, 1986) (table 3). The MCLs generally are set because elevated concentrations of these constituents may cause adverse health effects. The SMCLs generally are set for aesthetic reasons; elevated concentrations of these constituents may impart an undesirable taste or odor to water. Waters from both the unconfined and uppermost confined aquifers generally are suitable for domestic consumption, crop irrigation, and most other uses. Concentrations of major ions and constituents in water from both aquifers did not exceed the MCLs or SMCLs established by the USEPA for domestic consumption (table 3).

Concentrations of iron and manganese in water from the unconfined and uppermost confined aquifers frequently exceeded the USEPA established SMCL (table 3). The SMCL for iron was exceeded in 29 and 82 percent of the wells sampled for the unconfined and uppermost confined aquifers, respectively. The SMCL for manganese was exceeded in 55 and 88 percent of the wells sampled for the unconfined and uppermost confined aquifers, respectively. Dissolved iron and manganese are essential to plants and animals, but may cause objectionable taste, odors, and staining of plumbing fixtures at high concentrations. High concentrations of these ions do not adversely affect plants, but treatment of the water may be desirable prior to domestic use.

The suitability of water for irrigation commonly is determined by relating conductivity of the water to the sodium-adsorption ratio (SAR), which can be used to classify the water in terms of its sodium and salinity hazards. This classification system was developed by the U.S. Salinity Laboratory (1954). The SAR is determined by the following relation where constituent concentrations are expressed in milliequivalents per liter:

$$
\text { SAR }=\frac{\text { Sodium }}{\sqrt{\frac{(\text { Calcium }+ \text { Magnesium })}{2}}}
$$

A high SAR value indicates that irrigation can destroy soil structure and thereby reduce permeability.

Salinity is directly related to the dissolved solids in water. High salinity concentrations endanger plants through an increase in the osmotic pressure of the soil solution, thereby reducing the ability of roots to absorb water. Waters from the unconfined and uppermost confined aquifers exhibit a potentially low sodium hazard and a low to medium salinity hazard (fig. 32).

\section{Nutrients}

Nutrients include nitrogen and phosphorous species. Nitrogen is found in water principally as nitrate $\left(\mathrm{NO}_{3}\right)$, nitrite $\left(\mathrm{NO}_{2}\right)$, and ammonia $\left(\mathrm{NH}_{4}\right)$. Madison and Brunett (1984) evaluated nitrate concentrations nationwide and determined that concentration ranges of nitrate as nitrogen may indicate differences between human activities and naturally occurring nitrogen in the soil or geologic deposits. Nitrate concentrations less than $3 \mathrm{mg} / \mathrm{L}$ as nitrogen may indicate natural or ambient concentrations from naturally occurring soil nitrogen or geologic deposits. Concentrations larger than $3 \mathrm{mg} / \mathrm{L}$ as nitrogen may indicate effects from human activities. Significant sources of nitrate contamination include septic systems, fertilizers, livestock wastes, and industrial wastes.

The mean concentrations of dissolved nitrogen $\left(\mathrm{NO}_{2}\right.$ $+\mathrm{NO}_{3}$, dissolved) and total phosphorus were about 5 and 1.5 times greater for water from the unconfined aquifer than for water from the uppermost confined aquifer, respectively. Boxplots for concentrations of 
Table 3.--U.S. Environmental Protection Agency recommended limits for selected constituents in ground water and number of wells sampled where water exceeds the limits, Leech Lake Indian Reservation, Minnesota (U.S. Environmental Protection Agency, 1986)

[mg/L, milligrams per liter; $\mu \mathrm{g} / \mathrm{L}$, micrograms per liter]

\begin{tabular}{|c|c|c|c|c|c|c|}
\hline \multirow[b]{2}{*}{ Constituent } & \multirow[b]{2}{*}{$\begin{array}{l}\text { Established or } \\
\text { recommended } \\
\text { limits }\end{array}$} & \multirow[b]{2}{*}{$\begin{array}{c}\text { Source } \\
\text { (see footnote) }\end{array}$} & \multicolumn{2}{|c|}{ Unconfined aquifer } & \multicolumn{2}{|c|}{ Uppermost confined aquifer } \\
\hline & & & $\begin{array}{c}\text { Number of } \\
\text { wells sampled }\end{array}$ & $\begin{array}{l}\text { Number of } \\
\text { wells } \\
\text { exceeding } \\
\text { limits }\end{array}$ & $\begin{array}{c}\text { Number of } \\
\text { wells sampled }\end{array}$ & $\begin{array}{l}\text { Number of } \\
\text { wells } \\
\text { exceeding } \\
\text { limits }\end{array}$ \\
\hline Sodium & $270 \mathrm{mg} / \mathrm{L}$ & 3 & 31 & 0 & 17 & 0 \\
\hline Sulfate & $250 \mathrm{mg} / \mathrm{L}$ & 2 & 31 & 0 & 17 & 0 \\
\hline Chloride & $250 \mathrm{mg} / \mathrm{L}$ & 3 & 31 & 0 & 17 & 0 \\
\hline \multirow[t]{2}{*}{ Fluoride } & $4 \mathrm{mg} / \mathrm{L}$ & 1 & 31 & 0 & 17 & 0 \\
\hline & $2 \mathrm{mg} / \mathrm{L}$ & 2 & 31 & 0 & 17 & 0 \\
\hline Silica & $50 \mathrm{mg} / \mathrm{L}$ & 3 & 31 & 0 & 17 & 0 \\
\hline Dissolved solids & $500 \mathrm{mg} / \mathrm{L}$ & 2 & 31 & 0 & -- & -- \\
\hline $\begin{array}{l}\text { Nitrate (nitrate-plus- } \\
\text { nitrite as } \mathrm{N} \text { ) }\end{array}$ & $10 \mathrm{mg} / \mathrm{L}$ & 1 & 31 & 0 & 17 & 0 \\
\hline Arsenic & $50 \mu \mathrm{g} / \mathrm{L}$ & 1 & 7 & 0 & - & -- \\
\hline Boron & $750 \mu \mathrm{g} / \mathrm{L}$ & 3 & 31 & 0 & 17 & 0 \\
\hline Cadmium & $10 \mu \mathrm{g} / \mathrm{L}$ & 1 & 7 & 0 & -- & -- \\
\hline Chromium & $50 \mu \mathrm{g} / \mathrm{L}$ & 1 & 7 & 0 & -- & -- \\
\hline Copper & $1,000 \mu \mathrm{g} / \mathrm{L}$ & 1 & 7 & 0 & -- & -- \\
\hline Iron & $300 \mu \mathrm{g} / \mathrm{L}$ & 2 & 31 & 9 & 17 & 14 \\
\hline Lead & $50 \mu \mathrm{g} / \mathrm{L}$ & 1 & 7 & 0 & -- & -- \\
\hline Manganese & $50 \mu \mathrm{g} / \mathrm{L}$ & 2 & 31 & 17 & 17 & 15 \\
\hline Mercury & $2 \mu \mathrm{g} / \mathrm{L}$ & 1 & 4 & 0 & -- & -- \\
\hline Zinc & $5,000 \mu \mathrm{g} / \mathrm{L}$ & 2 & 7 & 1 & -- & - \\
\hline $2,4-\mathrm{D}$ & $100 \mu \mathrm{g} / \mathrm{L}$ & 1 & 3 & 0 & -- & -- \\
\hline Silvex & $10 \mathrm{mg} / \mathrm{L}$ & 1 & 3 & 0 & -- & -- \\
\hline
\end{tabular}

1. Maximum contaminant level established by the U.S. Environmental Protection Agency (1986).

2. Secondary maximum contaminant level established by the U.S. Environmental Protection Agency (1986).

3. Arbitrary limit suggested for public, livestock, and irrigation uses by the National Academy of Sciences and National Academy of Engineering (1974).

dissolved nitrogen and total phosphorus are shown in figure 30. The results of the analyses indicate that an elevated concentration (greater than $3 \mathrm{mg} / \mathrm{L}$ ) of dissolved nitrogen was found at only one site, in a well screened in the unconfined aquifer. The unconfined aquifer is closer to land surface and lacks overlying lowpermeability materials that could isolate the aquifer from direct infiltration of recharge and nutrients from sources at or near land surface. Nutrient concentrations greater than natural or ambient levels may result from infiltration of runoff from livestock feedlots, domestic septic systems, and fertilizers. A study conducted by
Detroy and others (1988, p. 18) in Iowa reported that the percentage of water samples collected that had nitrate concentrations greater than $10 \mathrm{mg} / \mathrm{L}$ as nitrogen increased with decreasing well depth; the largest percentage of these samples were collected from the depth interval between 1 and $50 \mathrm{ft}$. Studies conducted by Myette (1984) near Staples, Minn., indicate that concentrations of nitrate and chloride generally are greatest in water sampled from the shallowest part of the surficial aquifer (near the water table). Myette found that vertical mixing generally is minor, limited within the saturated part of the surficial aquifer because of 


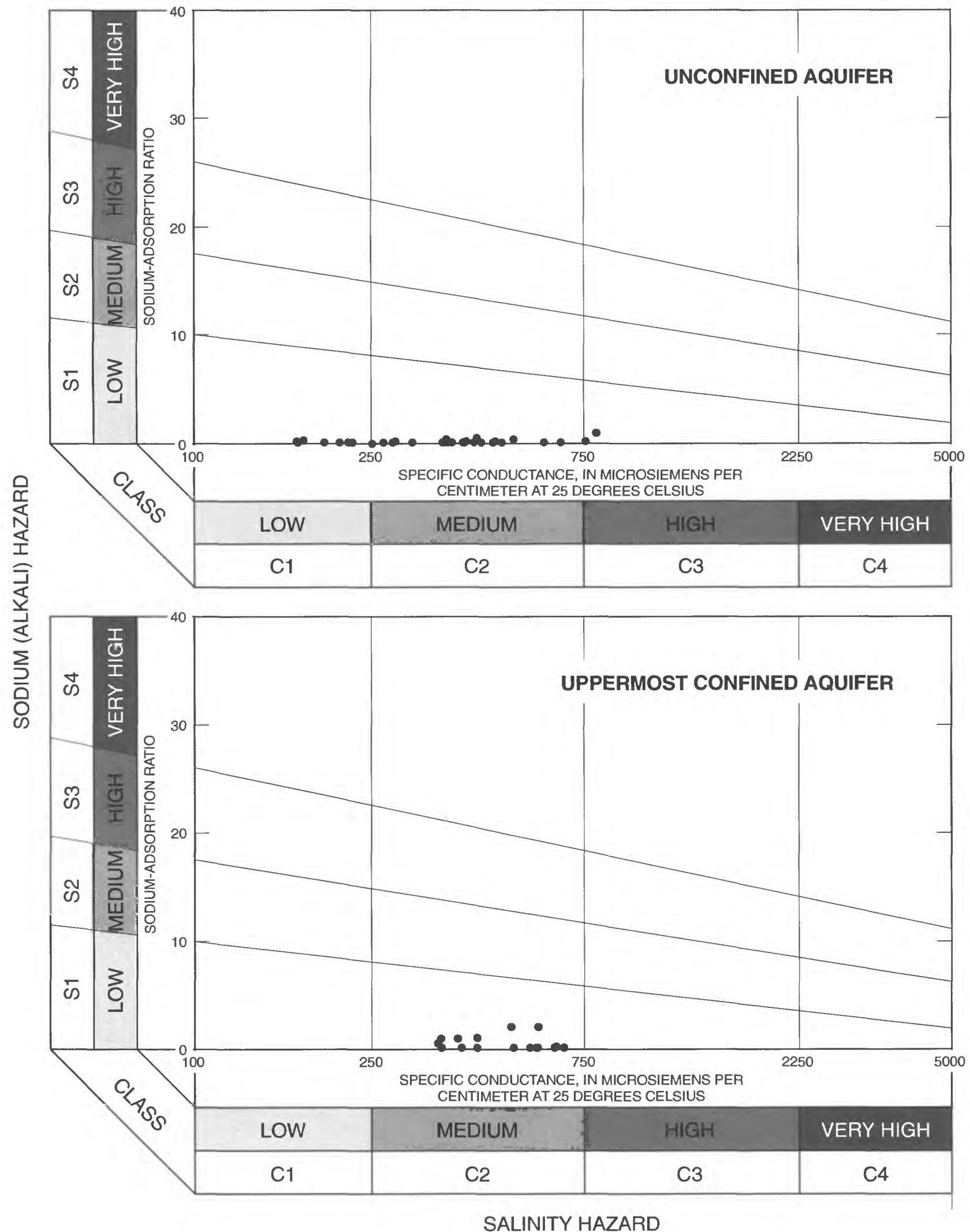

Figure 32. Suitability of water from the unconfined and uppermost confined aquifers for irrigation in terms of sodium and salinity hazards, Leech Lake Indian Reservation, Minnesota. 
anisotropy and the relatively short flow paths in these systems.

None of the water samples collected for this study had concentrations of dissolved nitrogen greater than the MCL established by the USEPA $(10 \mathrm{mg} / \mathrm{L})$ and only one water sample had a concentration greater than 3 $\mathrm{mg} / \mathrm{L}$. Forty-five percent of the water samples collected from wells screened in the unconfined aquifer had concentrations of dissolved nitrogen greater than the detection level $(0.1 \mathrm{mg} / \mathrm{L})$. Only 2 (12 percent) of the samples from wells screened in the uppermost confined aquifer had concentrations exceeding the detection level.

\section{Seasonal Variability in Ground-Water Quality}

Six wells screened in the unconfined aquifer were sampled during each of the four seasons during 1989-90 to determine the effect of seasonal changes on concentrations of chemical constituents (table 4). Seasonal changes in concentrations of chemical constituents are minimal, based on the data from the wells sampled.

\section{Ground-Water Quality Related to Land Use}

Water from wells completed in the unconfined aquifer in residential, recreational, and managed forest land-use areas was analyzed for specific groups of constituents whose possible presence might be related to land-use activities in those areas. Water collected from wells in residential and recreational land-use areas was analyzed for the presence of minor elements (table 5), including arsenic, cadmium, chromium, copper, lead, mercury, zinc, and cyanide. Concentrations of these minor elements did not exceed the MCLs established by the USEPA for domestic consumption in any waters from sampled wells, except for zinc. Concentrations of minor elements other than zinc were equal to or less than $6 \mu \mathrm{g} / \mathrm{L}$ and concentrations of cadmium, mercury, and cyanide were equal to or less than detection levels.

Concentrations of zinc locally exceed the SMCL established by the USEPA for domestic consumption (table 3). Zinc is an essential plant and animal nutrient, but may impart a metallic taste to water at high concentrations. The concentration of zinc in water from one well was $41,000 \mu \mathrm{g} / \mathrm{L}$. A probable source of high zinc concentrations in some wells is galvanized pipe.

Water samples were collected from three wells screened in the unconfined aquifer at managed forest land-use areas where herbicides had previously been applied (Nancy Salminen, U.S. Forest Service, Cass Lake, Minn., written commun., 1989). Water samples were analyzed for organic-acid herbicides, including the phenoxy-acid herbicides 2,4,-D; 2,4-DP; 2,4,5-T; and silvex; the benzoic-acid herbicide dicamba; and the substituted picolinic-acid compound picloram. Organic-acid herbicide concentrations in water collected from wells in managed forest land-use areas were all below detection levels (table 6).

One of the most serious consequences of the urbanization of many areas has been the introduction of man-made organic compounds into the subsurface environment. Some of these compounds have been entering the ground-water system for decades, but awareness of their presence in drinking water supplies did not begin until the mid-1970's when analytical techniques became available to detect their presence. The USEPA has classified 113 compounds, known as priority pollutants, as toxic organic compounds. These compounds are divided into four fractions by gas chromatography/mass spectroscopy analysis: (1) volatile compounds, (2) acidic compounds, (3) baseneutral compounds, and (4) pesticides. Water collected from 3 wells screened in the unconfined aquifer and from one well screened in the uppermost confined aquifer was analyzed for these USEPA priority pollutants (table 7). The concentrations of priority pollutants were below detection levels in water from all sampled wells.

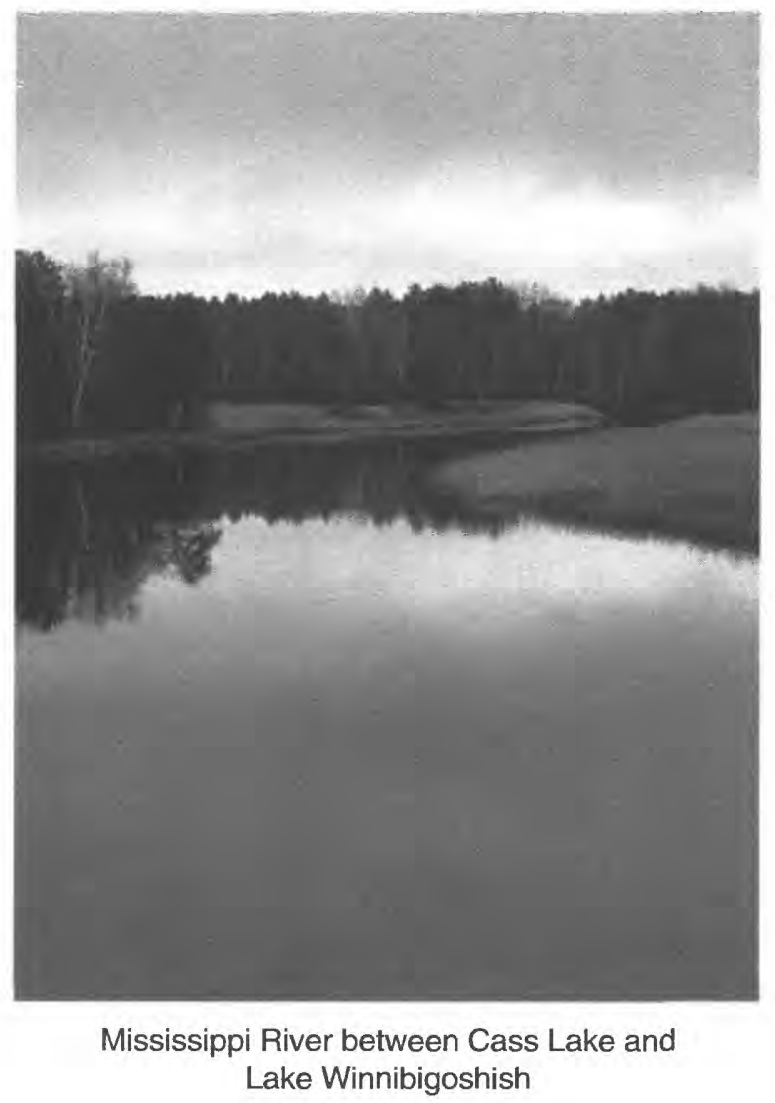




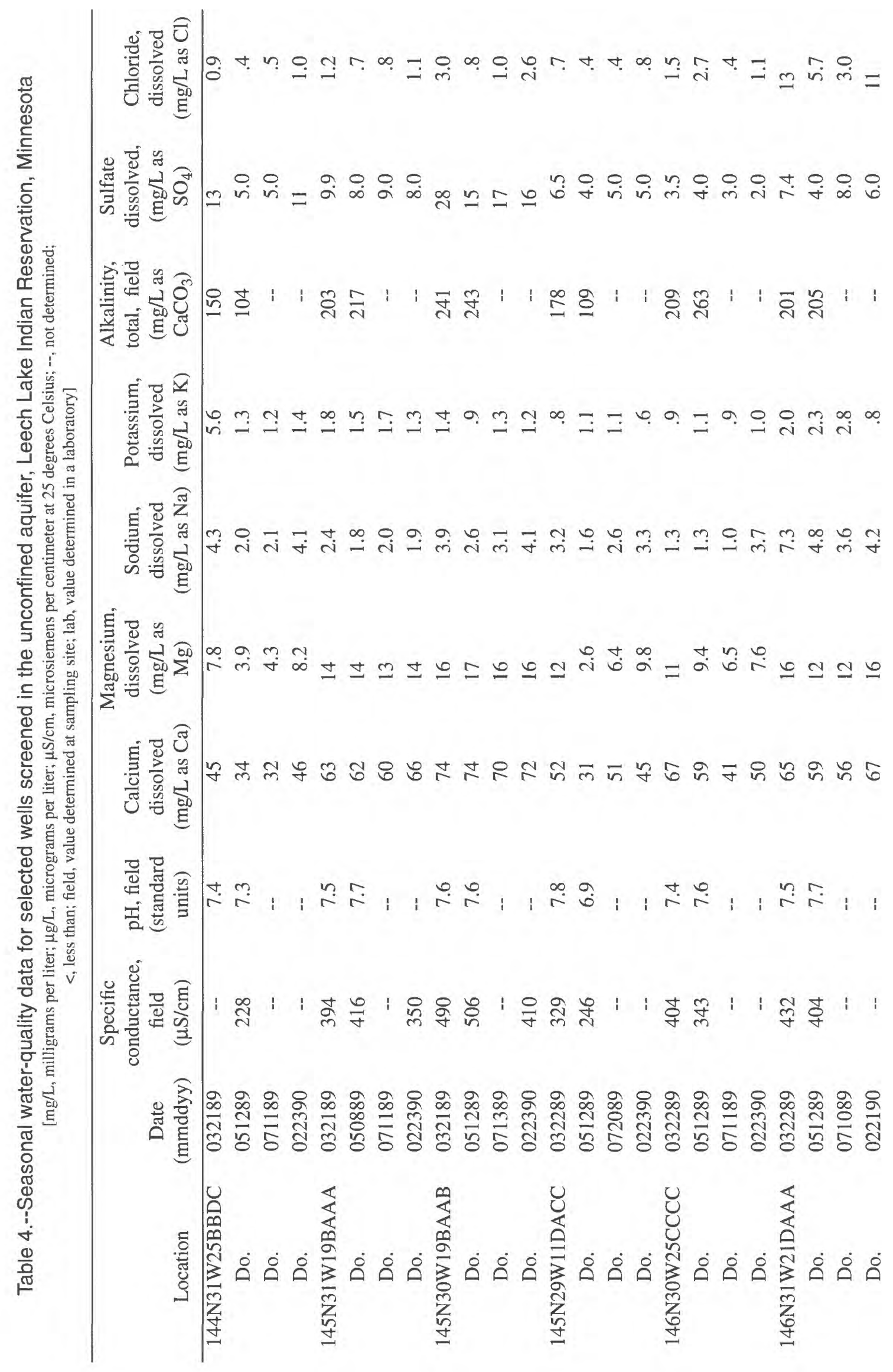




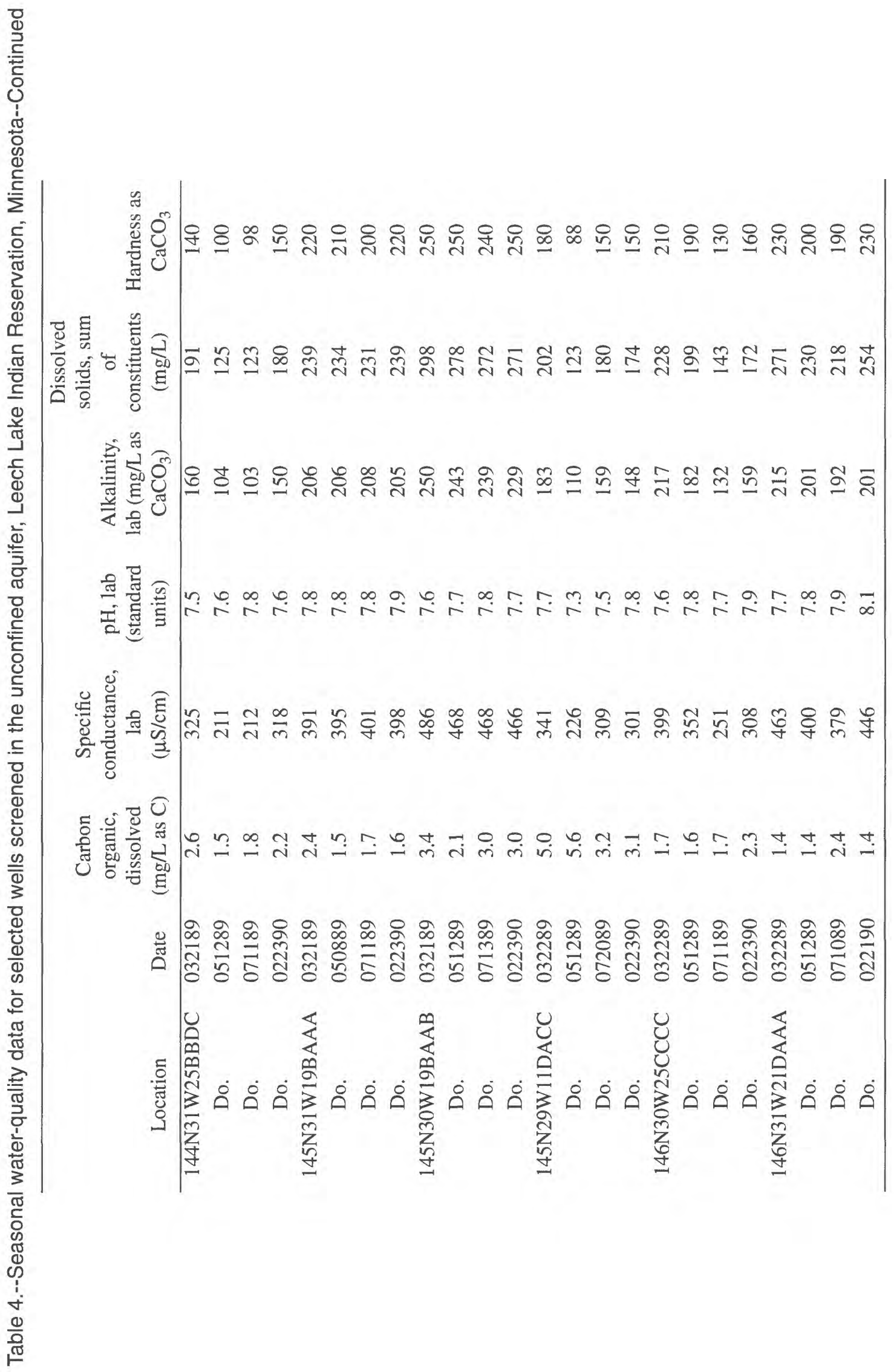




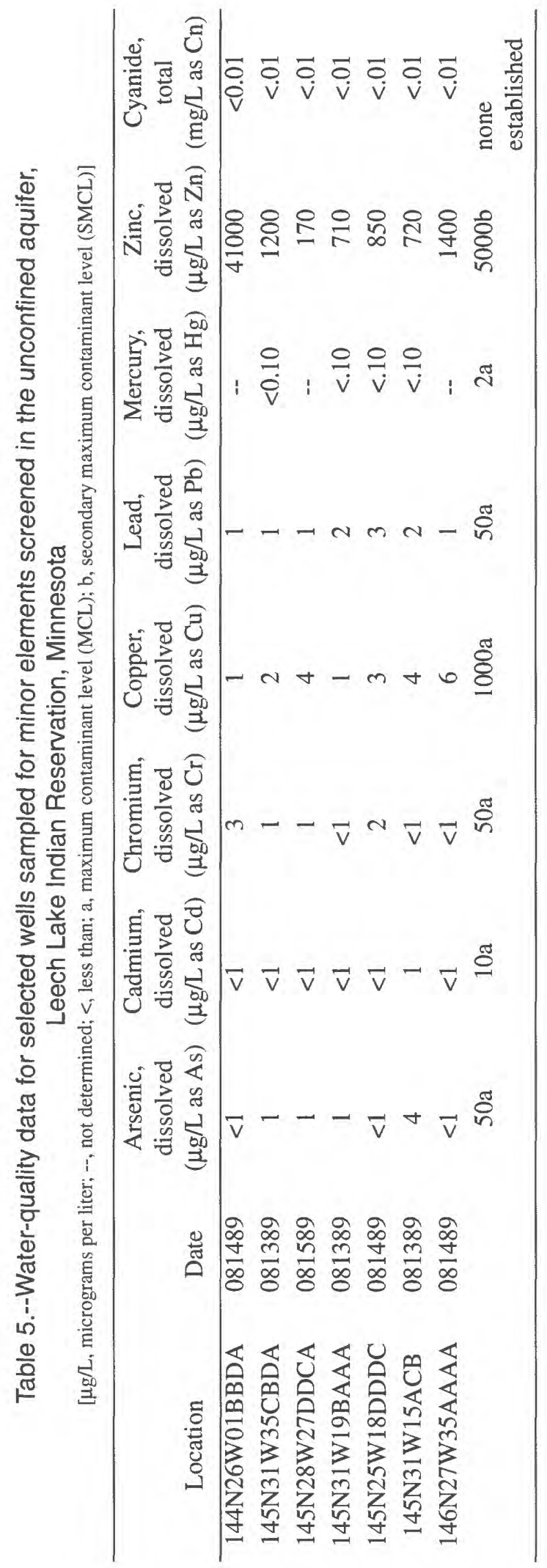


Table 6.--Water-quality data for selected wells sampled for herbicides screened in the unconfined aquifer, Leech Lake Indian Reservation, Minnesota

$[\mu \mathrm{g} / \mathrm{L}$, micrograms per liter; <, less than]

\begin{tabular}{cccccccc}
\hline Location & Date & $\begin{array}{c}2,4-\mathrm{D}, \text { Total } \\
(\mu \mathrm{g} / \mathrm{L})\end{array}$ & $\begin{array}{c}2,4-\mathrm{DP}, \\
\text { total }(\mu \mathrm{g} / \mathrm{L})\end{array}$ & $\begin{array}{c}2,4,5-\mathrm{T}, \\
\text { total }(\mu \mathrm{g} / \mathrm{L})\end{array}$ & $\begin{array}{c}\text { Dicamba, } \\
\text { total }(\mu \mathrm{g} / \mathrm{L})\end{array}$ & $\begin{array}{c}\text { Picloram, } \\
\text { total } \\
(\mu \mathrm{g} / \mathrm{L})\end{array}$ & $\begin{array}{c}\text { Silvex, total } \\
(\mu \mathrm{g} / \mathrm{L})\end{array}$ \\
\hline 145N30W24CDCC & 081489 & $<0.01$ & $<0.01$ & $<0.01$ & $<0.01$ & $<0.01$ & $<0.01$ \\
145N27W19CBCA & 081489 & $<.01$ & $<.01$ & $<.01$ & $<.01$ & $<.01$ & $<.01$ \\
145 N29W08CDCC & 081489 & $<.01$ & $<.01$ & $<.01$ & $<.01$ & $<.01$ & $<.01$ \\
\hline
\end{tabular}

Table 7.--Constituents determined for selected wells sampled for

U.S. Environmental Protection Agency priority pollutants

[Reporting level is the lowest measured concentration of a constituent that may be reliably reported using a given analytical method. The reporting level is set somewhat higher than the detection level; $\mu \mathrm{g} / \mathrm{L}$, micrograms per liter]

\begin{tabular}{lc}
\hline \multicolumn{1}{c}{ Constituent } & Reporting level \\
\hline Benzene $(\mu \mathrm{g} / \mathrm{L})$ & 3.0 \\
Bromoform $(\mu \mathrm{g} / \mathrm{L})$ & 3.0 \\
Carbon tetrachloride $(\mu \mathrm{g} / \mathrm{L})$ & 3.0 \\
Chlorobenzene $(\mu \mathrm{g} / \mathrm{L})$ & 3.0 \\
Chloroethane $(\mu \mathrm{g} / \mathrm{L})$ & 3.0 \\
& \\
2-Chloroethyl vinyl ether $(\mu \mathrm{g} / \mathrm{L})$ & 3.0 \\
Chloroform $(\mu \mathrm{g} / \mathrm{L})$ & 3.0 \\
Chloromethane $(\mu \mathrm{g} / \mathrm{L})$ & 3.0 \\
Dibromochloromethane $(\mu \mathrm{g} / \mathrm{L})$ & 3.0 \\
Dichlorobromomethane $(\mu \mathrm{g} / \mathrm{L})$ & 3.0 \\
& \\
1,2-Dichlorobenzene $(\mu \mathrm{g} / \mathrm{L})$ & 3.0 \\
1,3-Dichlorobenzene $(\mu \mathrm{g} / \mathrm{L})$ & 3.0 \\
1,4-Dichlorobenzene $(\mu \mathrm{g} / \mathrm{L})$ & 3.0 \\
Dichlorodifluoromethane $(\mu \mathrm{g} / \mathrm{L})$ & 3.0 \\
1,2-Dibromoethylene; $\mathrm{EDB}(\mu \mathrm{g} / \mathrm{L})$ & 3.0 \\
& \\
1,1-Dichloroethane $(\mu \mathrm{g} / \mathrm{L})$ & 3.0 \\
1,2-Dichloroethane $(\mu \mathrm{g} / \mathrm{L})$ & 3.0 \\
1,1-Dichloroethylene $(\mu \mathrm{g} / \mathrm{L})$ & 3.0 \\
1,2-trans-Dichloroethylene $(\mu \mathrm{g} / \mathrm{L})$ & 3.0 \\
1,2-Dichloropropane $(\mu \mathrm{g} / \mathrm{L})$ & 3.0 \\
Cis-1,3-Dichloropropene & 3.0 \\
Trans-1,3-Dichloropropene & 3.0 \\
1,3-Dichloropropene $(\mu \mathrm{g} / \mathrm{L})$ & 3.0 \\
Ethylbenzene $(\mu \mathrm{g} / \mathrm{L})$ & 3.0 \\
Methyl bromide $(\mu \mathrm{g} / \mathrm{L})$ & 3.0 \\
Styrene $(\mu \mathrm{g} / \mathrm{L})$ & 3.0 \\
Methylene chloride $(\mu \mathrm{g} / \mathrm{L})$ & \\
1,1,2,2-Tetrachloroethane $(\mu \mathrm{g} / \mathrm{L})$ & \\
& \\
& \\
&
\end{tabular}


Table 7.--Constituents determined for selected wells sampled for U.S. Environmental Protection Agency priority pollutants--Continued

\begin{tabular}{|c|c|}
\hline Constituent & Reporting level \\
\hline Tetrachloroethylene; PCE $(\mu \mathrm{g} / \mathrm{L})$ & 3.0 \\
\hline Toluene $(\mu \mathrm{g} / \mathrm{L})$ & 3.0 \\
\hline 1,1,1-Trichloroethane $(\mu \mathrm{g} / \mathrm{L})$ & 3.0 \\
\hline 1,1,2-Trichloroethane $(\mu \mathrm{g} / \mathrm{L})$ & 3.0 \\
\hline Trichloroethylene; TCE $(\mu \mathrm{g} / \mathrm{L})$ & 3.0 \\
\hline Vinyl chloride $(\mu \mathrm{g} / \mathrm{L})$ & 3.0 \\
\hline Xylenes, mixed $(\mu \mathrm{g} / \mathrm{L})$ & 3.0 \\
\hline 4-Chloro-3-methylphenol ( $\mu \mathrm{g} / \mathrm{L})$ & 30.0 \\
\hline 2-Chlorophenol $(\mu \mathrm{g} / \mathrm{L})$ & 5.0 \\
\hline 2,4-Dichlorophenol $(\mu \mathrm{g} / \mathrm{L})$ & 5.0 \\
\hline 2,4-Dimethylphenol $(\mu \mathrm{g} / \mathrm{L})$ & 5.0 \\
\hline 2,4-Dinitrophenol $(\mu \mathrm{g} / \mathrm{L})$ & 20.0 \\
\hline 4,6-Dinitro-2-methylphenol $(\mu \mathrm{g} / \mathrm{L})$ & 30.0 \\
\hline 2-Nitrophenol $(\mu \mathrm{g} / \mathrm{L})$ & 5.0 \\
\hline 4-Nitrophenol $(\mu \mathrm{g} / \mathrm{L})$ & 30.0 \\
\hline Pentachlorophenol $(\mu \mathrm{g} / \mathrm{L})$ & 30.0 \\
\hline Phenol $(\mu \mathrm{g} / \mathrm{L})$ & 5.0 \\
\hline 2,4,6-Trichlorophenol $(\mu \mathrm{g} / \mathrm{L})$ & 20.0 \\
\hline Acenaphthene $(\mu \mathrm{g} / \mathrm{L})$ & 5.0 \\
\hline Acenaphthylene $(\mu \mathrm{g} / \mathrm{L})$ & 5.0 \\
\hline Anthracene $(\mu \mathrm{g} / \mathrm{L})$ & 5.0 \\
\hline Benzo (a) anthracene $(\mu \mathrm{g} / \mathrm{L})$ & 10.0 \\
\hline Benzo (b) fluoranthene $(\mu \mathrm{g} / \mathrm{L})$ & 10.0 \\
\hline Benzo $(k)$ fluoranthene $(\mu \mathrm{g} / \mathrm{L})$ & 10.0 \\
\hline Benzo $(g, h, i$,$) perylene (\mu g / L)$ & 10.0 \\
\hline Benzo (a) pyrene $(\mu \mathrm{g} / \mathrm{L})$ & 10.0 \\
\hline 4-Bromophenyl phenyl ether $(\mu \mathrm{g} / \mathrm{L})$ & 5.0 \\
\hline Butyl benzyl phthalate $(\mu \mathrm{g} / \mathrm{L})$ & 5.0 \\
\hline bis (2-Chloroethoxy) methane $(\mu \mathrm{g} / \mathrm{L})$ & 5.0 \\
\hline bis (2-Chloroethyl) ether $(\mu \mathrm{g} / \mathrm{L})$ & 5.0 \\
\hline bis (2-Chloroisopropyl) ether ( $\mu \mathrm{g} / \mathrm{L}$ ) & 5.0 \\
\hline 2-Chloronaphthalene $(\mu \mathrm{g} / \mathrm{L})$ & 5.0 \\
\hline 4-Chlorophenyl phenyl ether $(\mu \mathrm{g} / \mathrm{L})$ & 5.0 \\
\hline Chrysene $(\mu \mathrm{g} / \mathrm{L})$ & 10.0 \\
\hline Dibenzo $(a, h)$ anthracene $(\mu \mathrm{g} / \mathrm{L})$ & 10.0 \\
\hline 1,2-Dichlorobenzene $(\mu \mathrm{g} / \mathrm{L})$ & 5.0 \\
\hline 1,3-Dichlorobenzene ( $\mu \mathrm{g} / \mathrm{L})$ & 5.0 \\
\hline 1,4-Dichlorobenzene $(\mu \mathrm{g} / \mathrm{L})$ & 5.0 \\
\hline Diethyl phthalate $(\mu \mathrm{g} / \mathrm{L})$ & 5.0 \\
\hline Dimethyl phthalate $(\mu \mathrm{g} / \mathrm{L})$ & 5.0 \\
\hline
\end{tabular}


Table 7.--Constituents determined for selected wells sampled for U.S. Environmental Protection Agency priority pollutants--Continued

\begin{tabular}{lc}
\multicolumn{1}{c}{ Constituent } & Reporting level \\
\hline Di-n-butyl phthalate $(\mu \mathrm{g} / \mathrm{L})$ & 5.0 \\
2,4-Dinitrotoluene $(\mu \mathrm{g} / \mathrm{L})$ & 5.0 \\
2,6-Dinitrotoluene $(\mu \mathrm{g} / \mathrm{L})$ & 5.0 \\
Di-n-octylphthalate $(\mu \mathrm{g} / \mathrm{L})$ & 10.0 \\
bis $(2-$ Ethylhexyl) phthalate $(\mu \mathrm{g} / \mathrm{L})$ & 5.0 \\
& \\
Fluoranthene $(\mu \mathrm{g} / \mathrm{L})$ & 5.0 \\
Fluorene $(\mu \mathrm{g} / \mathrm{L})$ & 5.0 \\
Hexachlorobenzene $(\mu \mathrm{g} / \mathrm{L})$ & 5.0 \\
Hexachlorobutadiene $(\mu \mathrm{g} / \mathrm{L})$ & 5.0 \\
Hexachlorocyclopentadiene $(\mu \mathrm{g} / \mathrm{L})$ & 5.0 \\
& \\
Hexachloroethane $(\mu \mathrm{g} / \mathrm{L})$ & 5.0 \\
Indeno $(1,2,3-\mathrm{cd})$ pyrene $(\mu \mathrm{g} / \mathrm{L})$ & 10.0 \\
Isophorone $(\mu \mathrm{g} / \mathrm{L})$ & 5.0 \\
Naphthalene $(\mu \mathrm{g} / \mathrm{L})$ & 5.0 \\
Nitrobenzene $(\mu \mathrm{g} / \mathrm{L})$ & 5.0 \\
& \\
n-Nitrosodimethylamine $(\mu \mathrm{g} / \mathrm{L})$ & 5.0 \\
n-Nitrosodi-n-propylamine $(\mu \mathrm{g} / \mathrm{L})$ & 5.0 \\
n-Mitrosodiphenylamine $(\mu \mathrm{g} / \mathrm{L})$ & 5.0 \\
Phenanthrene $(\mu \mathrm{g} / \mathrm{L})$ & 5.0 \\
Pyrene $(\mu \mathrm{g} / \mathrm{L})$ & 5.0 \\
1,2,4-Trichlorobenzene $(\mu \mathrm{g} / \mathrm{L})$ & 5.0 \\
\hline & \\
&
\end{tabular}

\section{Summary and Conclusions}

Aquifers and confining units are present throughout the entire thickness of the glacial drift in the study area, which covers approximately $2,145 \mathrm{mi}^{2}$ and includes parts of Beltrami, Hubbard, Itasca, and Cass Counties in north-central Minnesota. Three hydrogeologic units were defined for this study: (1) unconfined aquifer, (2) uppermost confining unit, and (3) uppermost confined aquifer.

The unconfined aquifer underlies most of the central and north-central parts of the study area. The total area underlain by the aquifer is approximately $655 \mathrm{mi}^{2}$ with the main outwash deposit underlying approximately 560 $\mathrm{mi}^{2}$. The unconfined aquifer generally consists of sand and fine gravel in the western part of the study area and fine to medium sand in the eastern part. Depth to the water table below land surface ranges from 0 to about $60 \mathrm{ft}$. The saturated thickness of the aquifer ranges from 0 to about $105 \mathrm{ft}$. The greatest saturated thicknesses occur in a north-south trending part of the aquifer between Pike Bay (Cass Lake) and Steamboat Bay (Leech Lake). The saturated thickness ranges from 15 to $30 \mathrm{ft}$ over most of the area and exceeds $20 \mathrm{ft}$ over approximately $210 \mathrm{mi}^{2}$. Estimates of horizontal hydraulic conductivity derived from 19 slug tests range from 0.6 to $31 \mathrm{ft} / \mathrm{d}$. The transmissivity of the aquifer ranges from 19 to more than $20,000 \mathrm{ft}^{2} / \mathrm{d}$ and is greatest in the area from west of Cass Lake to Lake Winnibigoshish. Reported well yields of as much as 2,000 gal/min may be possible in some areas, but are generally less than $250 \mathrm{gal} / \mathrm{min}$. Except in the Cass Lake area, the aquifer is not used extensively as a source of water to wells.

The unconfined and uppermost confined aquifers are physically and hydraulically separated by a fine-grained confining unit consisting of till or lake deposits. The thickness of the uppermost confining unit ranges from 3 to $254 \mathrm{ft}$ and is greatest near Jessie Lake in the northeastern part of the study area and southeast of Lake 
Winnibigoshish and generally is least in the western part of the study area.

The uppermost confined aquifer consists of buried deposits of sand and gravel that are bounded above by confining units of till or lake deposits. The altitude of the top of the uppermost confined aquifer ranges from about $1,110 \mathrm{ft}$ southeast of Lake Winnibigoshish to $1,350 \mathrm{ft}$ above sea level in the northwestern part of the study area. The thickness of the aquifer ranges from 5 to about $53 \mathrm{ft}$ and generally is greatest in the southeastern part of the study area. Published values of horizontal hydraulic conductivity for similar buried sand and gravel deposits in Minnesota range from 250 to $750 \mathrm{ft} / \mathrm{d}$. On the basis of specific-capacity data from domestic well logs, the transmissivity of the aquifer ranges from less than $100 \mathrm{ft}^{2} / \mathrm{d}$ in the northeastern and southeastern parts of the study area to about $21,000 \mathrm{ft}^{2} / \mathrm{d}$ near Cass Lake. Well yields of as much as 2,600 $\mathrm{gal} / \mathrm{min}$ are possible in some locations.

Recharge to the ground-water system is predominantly from precipitation that infiltrates to the saturated zone. Hydraulic heads in the aquifers generally are highest in the spring, during maximum recharge from snowmelt and rainfall. Heads generally are lowest in winter, when potential recharge from precipitation is stored at the land surface as snow. An analysis of four hydrographs for observation wells screened in the unconfined aquifer indicated spring recharge amounts during 1989 of 1-4 in.

Discharge from the ground-water system occurs by leakage to streams, lakes and wetlands, evapotranspiration, withdrawals by wells, and underflow to the southeast within the Mississippi River Valley. Streamflow measurements made on the Mississippi, Leech Lake, and Boy Rivers during February 1991 indicated that ground-water discharge to the Mississippi River is greater in the western part of the study area between Cass Lake and Lake Winnibigoshish than in the eastern part downstream from Lake Winnibigoshish.

The general pattern of flow in the ground-water system in the study area may be summarized as follows:

(1) Water enters the ground-water system by infiltration of precipitation and underflow from the west, north, and south.

(2) The predominant regional direction of groundwater flow is to the east and southeast, generally toward the Mississippi River, with a smaller area of flow toward Leech Lake in the southern part of the study area.
(3) Water moves predominantly horizontally through the aquifers, whereas vertical components of flow are significant in confining units.

(4) Water discharges by leakage to surface-water bodies and underflow to the southeast within the Mississippi River Valley.

The general direction of ground-water flow in the unconfined and uppermost confined aquifers is toward the Mississippi River and the three large lakes in the study area, Lake Winnibigoshish and Cass and Leech Lakes. The horizontal hydraulic gradient in the unconfined aquifer is about 10 to $20 \mathrm{ft} / \mathrm{mi}$ west and east of Cass Lake, north and southeast of Lake Winnibigoshish, and near Ball Club Lake. The horizontal hydraulic gradient is less than $10 \mathrm{ft} / \mathrm{mi}$ for the remainder of the study area. Altitude of the hydraulic head in the aquifer ranges from about $1,275 \mathrm{ft}$ near Ball Club Lake to about 1,350 ft northwest of Cass Lake and northeast of Lake Winnibigoshish.

The horizontal hydraulic gradient in the uppermost confined aquifer is about $70 \mathrm{ft} / \mathrm{mi}$ in the southwestern part of the study area, $50 \mathrm{ft} / \mathrm{mi}$ near Ball Club Lake, and 4-8 $\mathrm{ft} / \mathrm{mi}$ for the rest of the area. Hydraulic heads in the aquifer southeast of Ball Club Lake are above landsurface altitude and wells screened in the aquifer in this area will flow.

Downward leakage of water occurs in highland areas where ground water flows vertically through overlying till to the uppermost confined aquifer. Water moves vertically upward from deep to shallow aquifers in areas of regional discharge such as the Mississippi River, Cass Lake, Lake Winnibigoshish, and Leech Lake.

Ground-water samples were collected to (1) determine general ground-water quality, (2) define baseline water-quality data for use in future assessments of long-term trends, (3) determine seasonal changes in water quality, and (4) determine if ground-water quality has been affected by land-use practices. Water samples were collected from 48 wells during July and August of 1989 and during August 1990. Thirty one of the wells were screened in the unconfined aquifer and 17 wells were screened in the uppermost confined aquifer.

Selected properties of water include specific conductance, dissolved solids, $\mathrm{pH}$, alkalinity, and hardness. The median $\mathrm{pH}$ of water from the unconfined and uppermost confined aquifers are similar, 7.7 and 7.6 , respectively. The median specific conductance, median concentration of dissolved solids, and median alkalinity of water from the uppermost confined aquifer are 40,50, and 61 percent greater than for water from the unconfined aquifer, respectively. Water from both 
the unconfined and uppermost confined aquifers is hard to very hard, averaging 187 and $247 \mathrm{mg} / \mathrm{L}$ of calcium carbonate, respectively.

Calcium and bicarbonate are the predominant ions in water from both the unconfined and uppermost confined aquifers. Piper diagrams indicate that the relative concentrations of major cations and anions in water samples from the unconfined and uppermost confined aquifers are similar, indicating that mixing of water between the aquifers probably occurs.

The mean concentrations of chloride, manganese, dissolved organic carbon, sulfate, and dissolved iron were greater for water from the unconfined aquifer than for water from the uppermost confined aquifer. The mean concentrations of chloride and manganese for water from the unconfined aquifer were nearly double those for water from the uppermost confined aquifer.

Conversely, the mean concentrations of calcium, potassium, silica, sodium, fluoride, and boron for water from the uppermost confined aquifer were greater than for water from the unconfined aquifer. These higher concentrations of naturally occurring constituents in waters from the uppermost confined aquifer may occur because of the longer flow paths and longer residence times of water in the uppermost confined aquifer as compared to the unconfined aquifer.

Waters from both the unconfined and uppermost confined aquifers generally are suitable for domestic consumption, crop irrigation, and most other uses. Concentrations of major ions and constituents in water from both aquifers did not exceed MCLs or SMCLs established by the USEPA for domestic consumption. Concentrations of iron and manganese in water from both aquifers, however, frequently exceeded the USEPA established SMCLs. Waters from the unconfined and uppermost confined aquifers exhibit a potentially low sodium hazard and a low to medium salinity hazard for use as irrigation water.

Nutrients include nitrogen and phosphorus species. The mean concentrations of dissolved nitrogen $\left(\mathrm{NO}_{2}+\right.$ $\mathrm{NO}_{3}$, dissolved) and total phosphorus were about 5 and 1.5 times greater for water from the unconfined aquifer than for water from the uppermost confined aquifer, respectively. None of the water samples collected for this study had concentrations of dissolved nitrogen greater than the MCL established by the USEPA ( 10 $\mathrm{mg} / \mathrm{L})$.

Six wells screened in the unconfined aquifer were sampled during each of the four seasons during 198990. Seasonal changes in concentrations of chemical constituents were minimal, based on the data from the wells sampled.

Water from wells completed in the unconfined aquifer in residential, recreational, and managed forest land-use areas was analyzed for specific groups of constituents whose possible presence might be related to land-use activities in those areas. Water collected from wells in residential and recreational land-use areas had concentrations of arsenic, cadmium, chromium, copper, lead, mercury, and cyanide equal to or less than $6 \mu \mathrm{g} / \mathrm{L}$. Concentrations of zinc exceeded the SMCL established by the USEPA for domestic consumption in one well $(41.000 \mu \mathrm{g} / \mathrm{L})$.

Concentrations of organic acid herbicides (2,4-D; 2,4-DP; 2,4,5-T; dicamba; silvex; and picloram) sampled in water from three wells screened in the unconfined aquifer at managed-forest land-use areas were all below detection levels. Concentrations of USEPA priority pollutants in water from three wells screened in the unconfined aquifer and from one well screened in the uppermost confined aquifer also were below detection levels.

\section{References Cited}

Baker, D. G., and Kuenhast, E. A., 1978, Climate of Minnesota Part X, Precipitation normals for 19411970: Minnesota Agricultural Experimentation Station Technical Bulletin 314, 15p.

Baker, D. G., Nelson, W. W., and Kuehnast, E. A., 1979, Climate of Minnesota Part XII, The hydrologic cycle and soil and water: Minnesota Agricultural Experimentation Station Technical Bulletin 322, $23 \mathrm{p}$.

Bouwer, Herman, 1989, The Bouwer and Rice slug test-an update: Ground Water, v. 27, p. 304-309.

Bouwer, Herman, and Rice, R. C., 1976, A slug test for determining hydraulic conductivity of unconfined aquifers with completely or partially penetrating wells: Water Resources Research, v. 12, p. 423428.

Delin, G. N., 1986, Hydrogeology of confined-drift aquifers near the Pomme De Terre and Chippewa Rivers, Western Minnesota: U.S. Geological Survey Water Resources Investigations Report 864098, $90 \mathrm{p}$. 
Detroy, M.G., Hunt, P.K.B., and Holub, M.A., 1988, Ground-water-quality-monitoring program in Iowa; nitrate and pesticides in shallow aquifers: U.S. Geological Survey Water-Resources Investigations Report 88-4123, 31 p.

Durfor, C. N., and Becker, E., 1964, Public water supplies of the 100 largest cities in the United States, 1962: U.S. Geological Survey WaterSupply Paper 1812, 364 p.

Fishman, M. J., and Friedman, L. C., 1985, Methods for determination of inorganic substances in water and fluvial sediments: U.S. Geological Survey OpenFile Report 85-495, 709 p.

Freeze, R. A., and Cherry, J. A., 1979, Groundwater: Prentice-Hall, Inc., Englewood Cliffs, New Jersey, 604 p.

Heath, R. C., 1983, Basic ground-water hydrology: U.S. Geological Survey Water-Supply Paper 2220, 84p.

Helgesen, J. O., 1977, Ground-water appraisal of the Pineland Sands area, central Minnesota: U.S. Geological Survey Water-Resources Investigations Report 77-102, 49 p.

Hem, J. D., 1985, Study and interpretation of the chemical characteristics of natural waters: U.S. Geological Survey Water-Supply Paper 2245, $263 \mathrm{p}$.

Hobbs, H. G., and Goebel, J. E., 1982, Geologic Map of Minnesota, Quaternary Geology: Minnesota Geological Survey State Map Series S-1, 1 sheet, scale 1:500,000.

Lindholm, G. F., Helgesen, J. O., and Ericson, D. W., 1976, Water resources of the Big Fork River watershed, north-central Minnesota: U.S. Geological Survey Hydrologic Investigation Atlas HA-549, 2 sheets.

Lindholm, G. F., Oakes, E. L., Ericson, D. W., and Helgesen, J. O., 1972, Water resources of the Crow Wing River watershed, central Minnesota: U.S. Geological Survey Hydrologic Investigation Atlas HA- 380,4 sheets.

Lohman, S. W., 1972, Ground-water hydraulics: U.S. Geological Survey Professional Paper 708, 70 p.
Madison, R. J., and Brunett, J. O., 1984, Overview of the occurrence of nitrate in ground water of the United States, in National Water Summary 1984--WaterQuality Issues: U.S. Geological Survey WaterSupply Paper 2275, p. 93-103.

Meyer, R. R., 1963, A chart relating well diameter, specific capacity, and the coefficients of transmissibility and permeability, in Bentall, Ray, compiler, Methods of determining permeability, transmissibility, and drawdown: U.S. Geological Survey Water-Supply Paper 1536-I, p. 338-340.

Miller, R. T., 1982, Appraisal of the Pelican River sandplain aquifer, Western Minnesota: U.S. Geological Survey Open-File Report 82-347, 40 p.

Myette, C. F., 1984, Ground-water-quality appraisal of sand-plain aquifers in Hubbard, Morrison, Otter Tail, and Wadena Counties, Minnesota: U.S. Geological Survey Water-Resources Investigations Report 84-4080, 49 p.

National Academy of Sciences and National Academy of Engineering, 1974, Water Quality criteria, 1972: U.S. Government Printing Office, Washington, D.C.

Oakes, E. L., and Bidwell, L. E., 1968, Water Resources of the Mississippi Headwaters watershed, northcentral Minnesota: U.S. Geological Survey Hydrologic Investigation Atlas HA-278, 4 sheets.

Prudic, D. E., 1982, Hydraulic conductivity of a finegrained till, Cattaraugus County, New York: Ground Water, v. 20, no. 2, p. 194-204.

Rasmussen, W. C., and Andreasen, G. G., 1959, Hydrologic budget of the Beaver Dam Creek Basin, Maryland: U.S. Geological Survey WaterSupply Paper 1472, 106 p.

Sims, P. K., 1970, Geologic Map of Minnesota: Minnesota Geological Survey Miscellaneous Map Series, Map M-1, 1 sheet, scale 1:1,000,000.

Stark, J. R., Busch, J. P., and Deters, M. H., 1991, Hydrogeology and water quality of glacial-drift aquifers in the Bemidji-Bagley area, Beltrami, Clearwater, Cass, and Hubbard Counties, Minnesota: U.S. Geological Survey Water Resources Investigation 89-4136, 135 p.

U.S. Environmental Protection Agency, 1986, Quality criteria for water 1986: EPA-440/5-86-001. 
U.S. Salinity Laboratory, 1954, Diagnosis and improvement of saline and alkali soils: U.S. Department of Agriculture Handbook 60, 160 p.

Wershaw, R. L., Fishman, M. J., Grabbe, R. R., and Lowe, L. E., 1983, Methods for the determination of organic substances in water and fluvial sediments: U.S. Geological Survey Open-File Report 82-1004, 173 p.

Wright, H. E., Jr., 1972, Quaternary History of Minnesota: in P.K. Sims and G.B. Morey, eds., Geology of Minnesota: A Centennial Volume, Minnesota Geological Survey, p. 515-547.

Wright, H. E., Jr., 1973, Tunnel valleys, glacial surges, and subglacial hydrology of the Superior Lobe, Minnesota: in The Wisconsin Stage: Geological Society of America Memoir 136, p. 251-276.

Wright, H. E., Jr., Matsch, C. L., and Cushing, E. J., 1973, Superior and Des Moines Lobes: in The Wisconsin Stage: Geological Society of America Memoir 136, p. 153-185.

Wright, H. E., Jr., and Ruhe, R. V., 1965, Glaciation of Minnesota and Iowa, in H.E. Wright and D.G. Frey, eds., The Quaternary of the United States, University Press, Princeton, New Jersey, p. 29-41. 
Supplemental Information 
Table 8.--Selected data from commercial driller's logs of wells in the study area, Leech Lake Indian Reservation, Minnesota

[gal/min, gallon per minute; ft. foot; hr, hour; in., inch; ft/d, feet per day]

\begin{tabular}{|c|c|c|c|c|c|c|c|}
\hline Location & $\begin{array}{l}\text { Pumping } \\
\text { rate } \\
\text { (gal/min) }\end{array}$ & $\begin{array}{l}\text { Drawdown } \\
(\mathrm{ft})\end{array}$ & $\begin{array}{c}\text { Specific } \\
\text { capacity } \\
(\mathrm{gal} / \mathrm{min} / \mathrm{ft})\end{array}$ & $\begin{array}{l}\text { Pumping } \\
\text { time } \\
\text { (hr) }\end{array}$ & $\begin{array}{l}\text { Well } \\
\text { diameter } \\
\text { (in.) }\end{array}$ & $\begin{array}{l}\text { Well screen } \\
\text { length } \\
(\mathrm{ft})\end{array}$ & $\begin{array}{c}\text { Hydraulic } \\
\text { conductivity } \\
\text { per unit of } \\
\text { screen } \\
\text { length } \\
\text { (ft/d) }\end{array}$ \\
\hline 141N28W14DBBB & 60 & 17 & 3.53 & 7.0 & 4.00 & 8.0 & 112 \\
\hline 141N30W11ABBA1 & 10 & 2.0 & 5.00 & 1.0 & 4.00 & 4.0 & 282 \\
\hline 141N31W01BADC & 10 & 1.8 & 5.56 & 1.5 & 4.00 & 9.0 & 142 \\
\hline $142 \mathrm{~N} 30 \mathrm{~W} 17 \mathrm{BCBC}$ & 20 & 3.0 & 6.67 & 2.0 & 4.00 & 9.0 & 175 \\
\hline 142N30W17CACA1 & 20 & 7.5 & 2.67 & 2.0 & 4.00 & 9.0 & 70 \\
\hline $142 \mathrm{~N} 30 \mathrm{~W} 36 \mathrm{CBC}$ & 5 & 12 & 0.42 & 2.0 & 4.00 & 4.5 & 22 \\
\hline $142 \mathrm{~N} 31 \mathrm{~W} 28 \mathrm{DBBD}$ & 10 & 21.2 & 0.47 & 2.0 & 4.00 & 9.0 & 12 \\
\hline 143N29W24CDCDB & 20 & 6.8 & 2.94 & 1.2 & 4.00 & 8.0 & 84 \\
\hline 143N29W26CDDB3 & 12 & 11.6 & 1.03 & 1.5 & 4.00 & 4.0 & 60 \\
\hline 143N31W14BDCD & 8 & 18 & 0.44 & 2.0 & 2.00 & 8.0 & 14 \\
\hline $143 \mathrm{~N} 31 \mathrm{~W} 23 \mathrm{BBAB}$ & 12 & 4.0 & 3.00 & 1.0 & 4.00 & 4.0 & 169 \\
\hline 143N32W07DAADD & 11 & 5.0 & 2.20 & 1.0 & 4.00 & 8.0 & 62 \\
\hline 143N32W36DBCAB & 500 & 46 & 10.87 & 3.0 & 10.00 & 26.0 & 55 \\
\hline 144N28W21DBAA & 10 & 27 & 0.37 & 2.0 & 2.00 & 12.0 & 8 \\
\hline 144N31W04BBBB & 25 & 8.0 & 3.13 & 2.0 & 4.00 & 4.5 & 164 \\
\hline 144N31W06BCC & 12 & 40 & 0.30 & 1.0 & 4.00 & 8.0 & 8 \\
\hline 144N31W21CBBB & 12 & 3.7 & 3.24 & 1.0 & 4.00 & 4.0 & 182 \\
\hline $144 \mathrm{~N} 31 \mathrm{~W} 23 \mathrm{CBCC}$ & 20 & 14 & 1.43 & 2.0 & 4.00 & 9.0 & 37 \\
\hline 145N25W23CADD & 15 & 50 & 0.30 & 2.0 & 4.00 & 8.0 & 9 \\
\hline $145 \mathrm{~N} 25 \mathrm{~W} 31 \mathrm{BABB}$ & 20 & 47.5 & 0.42 & 2.0 & 4.00 & 8.0 & 12 \\
\hline 145N25W31DABB & 14 & 226 & 0.06 & 2.0 & 4.00 & 8.0 & 2 \\
\hline 145N26W05ACDB & 31 & 15.2 & 2.20 & 1.0 & 6.00 & 8.0 & 59 \\
\hline 145N26W21DDAD & 20 & 71.5 & 0.28 & 2.0 & 4.00 & 9.0 & 7 \\
\hline 145N28W29BDBD & 10 & 4.2 & 2.38 & 1.5 & 4.00 & 13.0 & 42 \\
\hline 145N28W30ABBAB & 11 & 7.0 & 1.57 & 1.0 & 4.00 & 4.0 & 88 \\
\hline 145N28W30BADBD & 12 & 4.3 & 2.79 & 2.3 & 4.00 & 4.0 & 166 \\
\hline $145 \mathrm{~N} 31 \mathrm{~W} 04 \mathrm{BCBC}$ & 20 & 10.2 & 1.96 & 1.0 & 2.00 & 13.0 & 37 \\
\hline $145 \mathrm{~N} 31 \mathrm{~W} 08 \mathrm{CCCB}$ & 170 & 5.4 & 31.48 & 6.0 & 6.00 & 13.0 & 458 \\
\hline 145N3IW08DAACD & 20 & 7.7 & 2.60 & 1.0 & 4.00 & 4.0 & 146 \\
\hline $145 \mathrm{~N} 31 \mathrm{~W} 09 \mathrm{CDCD}$ & 8 & 20.5 & 0.39 & 2.0 & 4.00 & 4.0 & 23 \\
\hline 145N31W21AAAB1 & 20 & 9.0 & 2.22 & 2.0 & 4.00 & 4.5 & 116 \\
\hline $145 \mathrm{~N} 31 \mathrm{~W} 21 \mathrm{AABA}$ & 20 & 13.5 & 1.48 & 2.0 & 4.00 & 4.5 & 60 \\
\hline 145N31W21DADDA & 20 & 12.5 & 1.60 & 2.0 & 4.00 & 9.0 & 42 \\
\hline $145 \mathrm{~N} 31 \mathrm{~W} 29 \mathrm{DABC}$ & 6 & 93 & 0.06 & 1.0 & 2.00 & 9.0 & 2 \\
\hline 145N32W03BBDBD & 10 & 12 & 0.83 & 1.0 & 2.00 & 4.0 & 51 \\
\hline $145 \mathrm{~N} 32 \mathrm{~W} 09 \mathrm{ACl}$ & 10 & 5.0 & 2.00 & 1.0 & 2.00 & 4.0 & 90 \\
\hline 145N32W09ACAAB & 300 & 61.5 & 4.88 & 24.0 & 8.00 & 25.0 & 49 \\
\hline
\end{tabular}


Table 8.--Selected data from commercial driller's logs of wells in the study area, Leech Lake Indian Reservation, Minnesota--Continued

\begin{tabular}{|c|c|c|c|c|c|c|c|}
\hline Location & $\begin{array}{l}\text { Pumping } \\
\text { rate } \\
\text { (gal } / \mathrm{min} \text { ) }\end{array}$ & $\begin{array}{l}\text { Drawdown } \\
\text { (ft) }\end{array}$ & $\begin{array}{c}\text { Specific } \\
\text { capacity } \\
(\mathrm{gal} / \mathrm{min} / \mathrm{ft})\end{array}$ & $\begin{array}{l}\text { Pumping } \\
\text { time (hr) }\end{array}$ & $\begin{array}{l}\text { Well } \\
\text { diameter } \\
\text { (in.) }\end{array}$ & $\begin{array}{l}\text { Well screen } \\
\text { length } \\
\text { (ft) }\end{array}$ & $\begin{array}{c}\text { Hydraulic } \\
\text { conductivity } \\
\text { per unit of } \\
\text { screen } \\
\text { length } \\
\text { (ft/d) }\end{array}$ \\
\hline 146N25W08DDDD & 10 & 4.7 & 2.13 & 2.0 & 2.00 & 12.0 & 46 \\
\hline 146N26W 18CDDC2 & 15 & 3.0 & 5.00 & 2.0 & 4.00 & 8.0 & 147 \\
\hline $146 \mathrm{~N} 27 \mathrm{~W} 03 \mathrm{DCA}$ & 15 & 23 & 0.65 & 1.0 & 4.00 & 5.0 & 20 \\
\hline 146N27W13DDDD & 10 & 6.0 & 1.67 & 1.0 & 4.00 & 36.0 & 11 \\
\hline $146 \mathrm{~N} 27 \mathrm{~W} 25 \mathrm{DABB}$ & 8 & 6.0 & 1.33 & 2.0 & 4.00 & 7.0 & 45 \\
\hline $146 \mathrm{~N} 27 \mathrm{~W} 25 \mathrm{DBAC}$ & 10 & 3.0 & 3.33 & 1.3 & 2.00 & 9.0 & 92 \\
\hline $146 \mathrm{~N} 29 \mathrm{~W} 35 \mathrm{AB}$ & 35 & 42 & 0.83 & 6.0 & 6.00 & 10.0 & 20 \\
\hline 146N30W07CDC & 20 & 2.3 & 8.70 & 2.0 & 4.00 & 4.0 & 511 \\
\hline 146N30W22BCCBA & 8 & 7.0 & 1.14 & 2.0 & 2.00 & 8.0 & 37 \\
\hline 146N30W22BDDDC & 20 & 5.6 & 3.57 & 1.0 & 4.00 & 8.0 & 101 \\
\hline 146N30W22DBABB & 20 & 6.1 & 3.28 & 2.0 & 4.00 & 9.0 & 86 \\
\hline 146N31W20DCDB & 20 & 2.2 & 9.09 & 1.2 & 4.00 & 8.0 & 186 \\
\hline 146N3 IW20DDBB & 10 & 1.5 & 6.67 & 40.0 & 6.00 & 4.0 & 449 \\
\hline 146N31W29AABD & 8 & 53 & 0.15 & 2.0 & 2.00 & 4.0 & 10 \\
\hline 146N31W29CBDA & 10 & 1.3 & 7.69 & 1.2 & 4.00 & 9.0 & 195 \\
\hline 146N31W30DADC & 10 & 5.0 & 2.00 & 0.83 & 6.00 & 4.0 & 73 \\
\hline 146N32W09AAB & 12 & 8.0 & 1.50 & 1.0 & 2.00 & 4.0 & 69 \\
\hline 147N25W14BCAD & 10 & 42 & 0.24 & 1.0 & 2.00 & 8.0 & 7 \\
\hline 147N26W01CADA1 & 20 & 1.0 & 20.00 & 2.0 & 4.00 & 8.0 & 589 \\
\hline 147N26W01CADC & 30 & 10 & 3.00 & 1.0 & 4.00 & 9.0 & 75 \\
\hline 147N26W08AADA2 & 20 & 8.0 & 2.50 & 2.0 & 4.00 & 9.0 & 65 \\
\hline $147 \mathrm{~N} 32 \mathrm{~W} 20 \mathrm{BAC}$ & 5 & 62 & 0.08 & 2.0 & 2.00 & 4.0 & 5 \\
\hline 147 N32W30CCB & 13 & 12 & 1.08 & 1.0 & 2.00 & 4.0 & 66 \\
\hline $148 \mathrm{~N} 25 \mathrm{~W} 24 \mathrm{DBAC}$ & 12 & 7.0 & 1.71 & 1.0 & 4.00 & 4.0 & 96 \\
\hline 148N26W26DCDD & 1 & 76.1 & 0.01 & 2.0 & 4.00 & 8.0 & 0.3 \\
\hline 148N27W17BACC & 10 & 29 & 0.34 & 1.0 & 2.00 & 8.0 & 10 \\
\hline $148 \mathrm{~N} 27 \mathrm{~W} 28 \mathrm{BCAB}$ & 20 & 18 & 1.11 & 2.0 & 4.00 & 9.0 & 29 \\
\hline $148 \mathrm{~N} 32 \mathrm{~W} 22 \mathrm{ABD}$ & 6 & 35 & 0.17 & 1.0 & 4.00 & 5.0 & 180 \\
\hline
\end{tabular}


Table 9.--Baseline water-quality data for wells screened in the unconfined aquifer,

Leech Lake Indian Reservation, Minnesota

[mg/L, milligrams per liter; $\mu \mathrm{g} / \mathrm{L}$, micrograms per liter; $\mu \mathrm{S} / \mathrm{cm}$ microsiemens per centimeter at 25 degrees Celsius; --, not determined; <, less than; field, value determined at sampling site; lab, value determined in a laboratory]

\begin{tabular}{|c|c|c|c|c|c|c|}
\hline Location & Date & $\begin{array}{c}\text { Specific } \\
\text { conductance, } \\
\text { field }(\mu S / \mathrm{cm})\end{array}$ & $\begin{array}{c}\mathrm{pH}, \text { field } \\
\text { (standard units) }\end{array}$ & $\begin{array}{c}\text { Calcium, } \\
\text { dissolved } \\
\text { (mg/L as } \mathrm{Ca} \text { ) }\end{array}$ & $\begin{array}{c}\text { Magnesium, } \\
\text { dissolved } \\
\text { (mg/L as } \mathrm{Mg} \text { ) }\end{array}$ & $\begin{array}{c}\text { Sodium } \\
\text { dissolved } \\
(\mathrm{mg} / \mathrm{L} \text { as } \mathrm{Na})\end{array}$ \\
\hline $144 \mathrm{~N} 28 \mathrm{~W} 27 \mathrm{CCBB}$ & 071989 & -- & -- & 67 & 13 & 13 \\
\hline $144 \mathrm{~N} 31 \mathrm{~W} 25 \mathrm{BBDC}$ & 071189 & -- & -- & 32 & 4.3 & 2.1 \\
\hline 144N27W05CABA & 072089 & -- & -- & 51 & 14 & 2.7 \\
\hline 144N26W01BBDA & 072089 & 889 & 7.2 & 120 & 24 & 8.9 \\
\hline $144 \mathrm{~N} 30 \mathrm{~W} 01 \mathrm{ABAB}$ & 072089 & -- & -- & 80 & 30 & 5.9 \\
\hline $145 \mathrm{~N} 28 \mathrm{~W} 34 \mathrm{CCAC}$ & 071989 & -- & -- & 40 & 6.7 & 4.4 \\
\hline $145 \mathrm{~N} 31 \mathrm{~W} 35 \mathrm{CBDA}$ & 071189 & -- & -- & 24 & 8.0 & 1.6 \\
\hline $145 \mathrm{~N} 27 \mathrm{~W} 36 \mathrm{CBAA}$ & 072089 & -- & -- & 52 & 7.3 & 13 \\
\hline 145N28W27DDCA & 071989 & -- & -- & 55 & 12 & 15 \\
\hline $145 \mathrm{~N} 30 \mathrm{~W} 24 \mathrm{CDCC}$ & 071289 & -- & -- & 48 & 4.4 & 2.2 \\
\hline $145 \mathrm{~N} 27 \mathrm{~W} 19 \mathrm{CBCA}$ & 071989 & -- & -- & 36 & 4.1 & 2.1 \\
\hline 145N31W19BAAA & 071189 & -- & -- & 60 & 13 & 2.0 \\
\hline $145 \mathrm{~N} 30 \mathrm{~W} 19 \mathrm{BAAB}$ & 071389 & -- & -- & 70 & 16 & 3.1 \\
\hline 145N25W18DDDC & 072089 & 917 & 7.6 & 84 & 24 & 45 \\
\hline $145 \mathrm{~N} 31 \mathrm{~W} 15 \mathrm{ACB}$ & 071289 & -- & -- & 110 & 16 & 3.1 \\
\hline $145 \mathrm{~N} 31 \mathrm{~W} 18 \mathrm{BABD}$ & 071189 & - & - & 60 & 14 & 2.1 \\
\hline $145 \mathrm{~N} 29 \mathrm{~W} 08 \mathrm{CDCC}$ & 071289 & - & - & 69 & 14 & 2.1 \\
\hline 145N31W08DAAC & 082290 & - & 7.8 & 59 & 13 & 5.4 \\
\hline 145N29W11DACC & 072089 & - & -- & 51 & 6.4 & 2.6 \\
\hline $145 \mathrm{~N} 29 \mathrm{~W} 09 \mathrm{ACAC}$ & 071289 & - & -- & 56 & 12 & 3.1 \\
\hline 145N27W04DCCC & 071989 & - & -- & 21 & 5.3 & 6.3 \\
\hline 146N29W31DBDB & 071989 & - & - & 24 & 6.1 & 1.3 \\
\hline $146 \mathrm{~N} 29 \mathrm{~W} 33 \mathrm{BCDB}$ & 071289 & - & -- & 49 & 15 & 3.3 \\
\hline 146N27W35AAAA & 071889 & -- & -- & 54 & 23 & 7.5 \\
\hline 146N30W34BBBB & 071189 & - & - & 34 & 5.9 & 2.5 \\
\hline $146 \mathrm{~N} 30 \mathrm{~W} 25 \mathrm{CCCC}$ & 071189 & -- & -- & 41 & 6.5 & 1.0 \\
\hline $146 \mathrm{~N} 31 \mathrm{~W} 29 \mathrm{CBBB}$ & 071189 & - & -- & 66 & 18 & 4.8 \\
\hline 146N31W21DAAA & 071089 & - & -- & 56 & 12 & 3.6 \\
\hline 147N31W22DCCC & 071089 & -- & - & 62 & 16 & 2.9 \\
\hline 147N27W14DACC & 071889 & - & -- & 20 & 5.1 & 3.8 \\
\hline 148N27W35BAAD & 071889 & -- & -- & 36 & 12 & 1.8 \\
\hline
\end{tabular}


Table 9.--Baseline water-quality data for wells screened in the unconfined aquifer, Leech Lake Indian Reservation, Minnesota--Continued

\begin{tabular}{|c|c|c|c|c|c|c|}
\hline Location & Date & $\begin{array}{l}\text { Potassium, } \\
\text { dissolved } \\
\text { (mg/L as K) }\end{array}$ & $\begin{array}{l}\text { Alkalinity, total, } \\
\text { field }(\mathrm{mg} / \mathrm{L} \text { as } \\
\left.\mathrm{CaCO}_{3}\right)\end{array}$ & $\begin{array}{c}\text { Sulfate, } \\
\text { dissolved } \\
\left(\mathrm{mg} / \mathrm{L} \text { as } \mathrm{SO}_{4}\right)\end{array}$ & $\begin{array}{l}\text { Chloride, } \\
\text { dissolved } \\
(\mathrm{mg} / \mathrm{L} \text { as } \mathrm{Cl})\end{array}$ & $\begin{array}{l}\text { Fluoride, } \\
\text { dissolved } \\
\text { (mg/L as F) }\end{array}$ \\
\hline 144N28W27CCBB & 071989 & 1.9 & -- & 6.0 & 40 & 0.1 \\
\hline 144N31W25BBDC & 071189 & 1.2 & -- & 5.0 & .5 & .1 \\
\hline 144N27W05CABA & 072089 & .5 & -- & 4.0 & .6 & .1 \\
\hline 144N26W01BBDA & 072089 & 5.3 & - & 16 & 15 & .2 \\
\hline 144N30W01ABAB & 072089 & 3.2 & -- & 3.0 & .5 & .1 \\
\hline 145N28W34CCAC & 071989 & 1.2 & - & 11 & 6.2 & .1 \\
\hline 145N31W35CBDA & 071189 & 1.8 & - & 1.0 & 0.8 & .1 \\
\hline $145 \mathrm{~N} 27 \mathrm{~W} 36 \mathrm{CBAA}$ & 072089 & 3.8 & - & 6.0 & 19 & .1 \\
\hline 145N28W27DDCA & 071989 & .7 & - & 11 & 25 & .1 \\
\hline $145 \mathrm{~N} 30 \mathrm{~W} 24 \mathrm{CDCC}$ & 071289 & .4 & -- & 1.0 & .7 & .2 \\
\hline $145 \mathrm{~N} 27 \mathrm{~W} 19 \mathrm{CBCA}$ & 071989 & 1.3 & -- & 2.0 & .7 & .1 \\
\hline 145N31W19BAAA & 071189 & 1.7 & - & 9.0 & .8 & .1 \\
\hline 145N30W19BAAB & 071389 & 1.3 & - & 17.0 & 1.0 & .1 \\
\hline 145N25W18DDDC & 072089 & 1.0 & -- & 9.0 & 94 & .1 \\
\hline $145 \mathrm{~N} 31 \mathrm{~W} 15 \mathrm{ACB}$ & 071289 & 1.2 & -- & 6.0 & .7 & .1 \\
\hline 145N31W18BABD & 071189 & .9 & -- & 4.0 & .8 & .1 \\
\hline $145 \mathrm{~N} 29 \mathrm{~W} 08 \mathrm{CDCC}$ & 071289 & .6 & -- & 3.0 & .5 & .2 \\
\hline 145N31W08DAAC & 082290 & 3.9 & 184 & 9.1 & 2.4 & .3 \\
\hline 145N29W11DACC & 072089 & 1.1 & -- & 5.0 & .4 & .1 \\
\hline 145N29W09ACAC & 071289 & .7 & -- & 9.0 & .5 & .1 \\
\hline 145N27W04DCCC & 071989 & 2.1 & -- & 4.0 & 1.8 & .1 \\
\hline 146N29W31DBDB & 071989 & 6 & -- & 1.0 & .3 & .1 \\
\hline $146 \mathrm{~N} 29 \mathrm{~W} 33 \mathrm{BCDB}$ & 071289 & 1.1 & -- & 5.0 & .5 & .1 \\
\hline 146N27W35AAAA & 071889 & 1.1 & -- & 6.0 & 27 & .1 \\
\hline 146N30W34BBBB & 071189 & .4 & -- & 6.0 & .4 & .1 \\
\hline $146 \mathrm{~N} 30 \mathrm{~W} 25 \mathrm{CCCC}$ & 071189 & .9 & -- & 3.0 & .4 & .1 \\
\hline $146 \mathrm{~N} 31 \mathrm{~W} 29 \mathrm{CBBB}$ & 071189 & 1.9 & -- & 8.0 & 4.0 & .1 \\
\hline 146N31W21DAAA & 071089 & 2.8 & -- & 8.0 & 3.0 & .1 \\
\hline 147N31W22DCCC & 071089 & 1.5 & -- & 6.0 & .9 & .1 \\
\hline 147N27W14DACC & 071889 & .9 & -- & 9.0 & 1.0 & .1 \\
\hline 148N27W35BAAD & 071889 & .5 & -- & 3.0 & 1.0 & .1 \\
\hline
\end{tabular}


Table 9.--Baseline water-quality data for wells screened in the unconfined aquifer, Leech Lake Indian Reservation, Minnesota--Continued

\begin{tabular}{|c|c|c|c|c|c|c|}
\hline Location & Date & $\begin{array}{l}\text { Silica, dissolved } \\
\left(\mathrm{mg} / \mathrm{L} \text { as } \mathrm{SiO}_{2}\right)\end{array}$ & $\begin{array}{c}\text { Nitrogen, } \\
\mathrm{NO}_{2}+\mathrm{NO}_{3} \text {, } \\
\text { dissolved } \\
(\mathrm{mg} / \mathrm{L} \text { as } \mathrm{N})\end{array}$ & $\begin{array}{c}\text { Nitrogen, } \\
\text { ammonia, } \\
\text { dissolved, }(\mathrm{mg} / \mathrm{L} \\
\text { as } \mathrm{N})\end{array}$ & $\begin{array}{c}\text { Phosphorus, } \\
\text { total } \\
\text { (mg/L as } \mathrm{P} \text { ) }\end{array}$ & $\begin{array}{c}\text { Phosphorus } \\
\text { ortho, } \\
\text { dissolved, (mg/L } \\
\text { as } \mathrm{P})\end{array}$ \\
\hline 144N28W27CCBB & 071989 & 11 & 0.460 & 0.12 & 0.02 & $<0.01$ \\
\hline 144N3IW25BBDC & 071189 & 16 & $<.10$ & $<.01$ & .01 & .02 \\
\hline 144N27W05CABA & 072089 & 24 & $<.10$ & .02 & .08 & .06 \\
\hline 144N26W01BBDA & 072089 & 38 & $<.10$ & .87 & .16 & .40 \\
\hline $144 \mathrm{~N} 30 \mathrm{~W} 01 \mathrm{ABAB}$ & 072089 & 22 & $<.10$ & .24 & .01 & .02 \\
\hline $145 \mathrm{~N} 28 \mathrm{~W} 34 \mathrm{CCAC}$ & 071989 & 17 & .57 & .02 & .05 & .04 \\
\hline $145 \mathrm{~N} 31 \mathrm{~W} 35 \mathrm{CBDA}$ & 071189 & 14 & $<.10$ & .06 & .05 & .05 \\
\hline $145 \mathrm{~N} 27 \mathrm{~W} 36 \mathrm{CBAA}$ & 072089 & 13 & $<.10$ & .02 & .02 & .03 \\
\hline 145N28W27DDCA & 071989 & 22 & 2.9 & $<.01$ & .07 & .07 \\
\hline $145 \mathrm{~N} 30 \mathrm{~W} 24 \mathrm{CDCC}$ & 071289 & 16 & $<.10$ & .05 & .02 & .01 \\
\hline $145 \mathrm{~N} 27 \mathrm{~W} 19 \mathrm{CBCA}$ & 071989 & 16 & $<.10$ & .03 & .70 & .04 \\
\hline 145N31W19BAAA & 071189 & 19 & .14 & .03 & .03 & .02 \\
\hline $145 \mathrm{~N} 30 \mathrm{~W} 19 \mathrm{BAAB}$ & 071389 & 20 & $<.10$ & .04 & $<.01$ & $<.01$ \\
\hline 145N25W18DDDC & 072089 & 21 & .16 & .03 & .03 & $<.01$ \\
\hline $145 \mathrm{~N} 31 \mathrm{~W} 15 \mathrm{ACB}$ & 071289 & 29 & $<.10$ & .14 & .01 & $<.01$ \\
\hline 145N31W18BABD & 071189 & 19 & 1.0 & .03 & .02 & .02 \\
\hline $145 \mathrm{~N} 29 \mathrm{~W} 08 \mathrm{CDCC}$ & 071289 & 19 & .37 & .02 & .05 & .03 \\
\hline 145N31W08DAAC & 082290 & 21 & 4.2 & .02 & 1.1 & 1.1 \\
\hline 145N29W11DACC & 072089 & 18 & $<.10$ & .02 & .21 & .02 \\
\hline 145N29W09ACAC & 071289 & 18 & $<.10$ & .02 & .01 & .02 \\
\hline 145N27W04DCCC & 071989 & 5.7 & 2.3 & .04 & .07 & .02 \\
\hline 146N29W31DBDB & 071989 & 15 & .86 & .01 & .09 & .04 \\
\hline $146 \mathrm{~N} 29 \mathrm{~W} 33 \mathrm{BCDB}$ & 071289 & 14 & $<.10$ & .05 & $<.01$ & .01 \\
\hline 146N27W35AAAA & 071889 & 20 & 2.3 & .03 & .05 & .04 \\
\hline 146N30W34BBBB & 071189 & 18 & $<.10$ & $<.01$ & .04 & .02 \\
\hline $146 \mathrm{~N} 30 \mathrm{~W} 25 \mathrm{CCCC}$ & 071189 & 10 & .11 & $<.01$ & .01 & .01 \\
\hline $146 \mathrm{~N} 31 \mathrm{~W} 29 \mathrm{CBBB}$ & 071189 & 18 & $<.10$ & .30 & .03 & .01 \\
\hline 146N31W21DAAA & 071089 & 16 & .30 & .02 & $<.01$ & $<.01$ \\
\hline 147N31W22DCCC & 071089 & 20 & $<.10$ & .04 & .05 & .03 \\
\hline 147N27W14DACC & 071889 & 19 & $<.10$ & .07 & .18 & .03 \\
\hline 148N27W35BAAD & 071889 & 22 & .78 & .02 & .17 & .03 \\
\hline
\end{tabular}


Table 9.--Baseline water-quality data for wells screened in the unconfined aquifer, Leech Lake Indian Reservation, Minnesota--Continued

\begin{tabular}{|c|c|c|c|c|c|c|}
\hline Location & Date & $\begin{array}{c}\text { Boron, dissolved } \\
(\mu \mathrm{g} / \mathrm{L} \text { as } \mathrm{B})\end{array}$ & $\begin{array}{l}\text { Iron, dissolved } \\
(\mu \mathrm{g} / \mathrm{L} \text { as } \mathrm{Fe})\end{array}$ & $\begin{array}{c}\text { Manganese, } \\
\text { dissolved } \\
(\mu \mathrm{g} / \mathrm{L} \text { as } \mathrm{Mn})\end{array}$ & $\begin{array}{c}\text { Carbon, organic } \\
\text { dissolved } \\
(\mathrm{mg} / \mathrm{L} \text { as } \mathrm{C})\end{array}$ & $\begin{array}{c}\text { Specific } \\
\text { conductance, } \\
\text { lab }(\mu \mathrm{S} / \mathrm{cm})\end{array}$ \\
\hline 144N28W27CCBB & 071989 & $<10$ & 8 & 160 & 2.0 & 521 \\
\hline $144 \mathrm{~N} 31 \mathrm{~W} 25 \mathrm{BBDC}$ & 071189 & $<10$ & 33 & 170 & 1.8 & 212 \\
\hline 144N27W05CABA & 072089 & 20 & 10 & 50 & 2.0 & 361 \\
\hline 144N26W01BBDA & 072089 & 40 & 8100 & 280 & 38 & 756 \\
\hline 144N30W01ABAB & 072089 & 20 & 1900 & 110 & 1.7 & 610 \\
\hline $145 \mathrm{~N} 28 \mathrm{~W} 34 \mathrm{CCAC}$ & 071989 & 10 & 260 & 510 & 2.7 & 283 \\
\hline $145 \mathrm{~N} 31 \mathrm{~W} 35 \mathrm{CBDA}$ & 071189 & 10 & 1800 & 220 & 11 & 196 \\
\hline $145 \mathrm{~N} 27 \mathrm{~W} 36 \mathrm{CBAA}$ & 072089 & 30 & 890 & 550 & 3.6 & 368 \\
\hline 145N28W27DDCA & 071989 & 40 & 12 & $<1$ & 1.0 & 431 \\
\hline $145 \mathrm{~N} 30 \mathrm{~W} 24 \mathrm{CDCC}$ & 071289 & 20 & 550 & 190 & 10 & 279 \\
\hline $145 \mathrm{~N} 27 \mathrm{~W} 19 \mathrm{CBCA}$ & 071989 & $<10$ & 490 & 340 & 4.5 & 227 \\
\hline 145N31W19BAAA & 071189 & $<10$ & 15 & 45 & 1.7 & 401 \\
\hline $145 \mathrm{~N} 30 \mathrm{~W} 19 \mathrm{BAAB}$ & 071389 & $<10$ & 62 & 50 & 3.0 & 468 \\
\hline 145N25W18DDDC & 072089 & 100 & 160 & 790 & 4.9 & 800 \\
\hline $145 \mathrm{~N} 31 \mathrm{~W} 15 \mathrm{ACB}$ & 071289 & 70 & 20000 & 2800 & 3.5 & 665 \\
\hline $145 \mathrm{~N} 31 \mathrm{~W} 18 \mathrm{BABD}$ & 071189 & 30 & 22 & 230 & 2.2 & 405 \\
\hline $145 \mathrm{~N} 29 \mathrm{~W} 08 \mathrm{CDCC}$ & 071289 & $<10$ & 6 & 20 & 1.8 & 441 \\
\hline 145N31W08DAAC & 082290 & 30 & 12 & 4 & 2.1 & 408 \\
\hline 145N29W11DACC & 072089 & $<10$ & 65 & 84 & 3.2 & 309 \\
\hline 145N29W09ACAC & 071289 & $<10$ & 25 & 130 & 1.6 & 363 \\
\hline 145N27W04DCCC & 071989 & $<10$ & 10 & 19 & 1.1 & 176 \\
\hline 146N29W31DBDB & 071989 & 20 & 11 & 14 & 6 & 171 \\
\hline 146N29W33BCDB & 071289 & 20 & 49 & 440 & 1.6 & 371 \\
\hline $146 \mathrm{~N} 27 \mathrm{~W} 35 \mathrm{AAAA}$ & 071889 & 10 & 6 & 30 & 1.9 & 474 \\
\hline 146N30W34BBBB & 071189 & $<10$ & 31 & 38 & 1.3 & 222 \\
\hline $146 \mathrm{~N} 30 \mathrm{~W} 25 \mathrm{CCCC}$ & 071189 & $<10$ & 7 & 4 & 1.7 & 251 \\
\hline $146 \mathrm{~N} 31 \mathrm{~W} 29 \mathrm{CBBB}$ & 071189 & 10 & 1600 & 220 & 5.7 & 490 \\
\hline 146N31W21DAAA & 071089 & 30 & 13 & 3 & 2.4 & 379 \\
\hline 147N31W22DCCC & 071089 & 10 & 12 & 11 & 3.4 & 425 \\
\hline 147N27W14DACC & 071889 & $<10$ & 1100 & 160 & 4.2 & 170 \\
\hline $148 \mathrm{~N} 27 \mathrm{~W} 35 \mathrm{BAAD}$ & 071889 & 30 & 19 & 21 & 2.0 & 266 \\
\hline
\end{tabular}


Table 9.--Baseline water-quality data for wells screened in the unconfined aquifer, Leech Lake Indian Reservation, Minnesota--Continued

\begin{tabular}{|c|c|c|c|c|c|}
\hline Location & Date & $\begin{array}{c}\text { pH lab (standard } \\
\text { units) }\end{array}$ & $\begin{array}{c}\text { Alkalinity lab } \\
\left(\mathrm{mg} / \mathrm{L} \text { as } \mathrm{CaCO}_{3}\right)\end{array}$ & $\begin{array}{l}\text { Dissolved } \\
\text { solids, sum of } \\
\text { constituents } \\
(\mathrm{mg} / \mathrm{L})\end{array}$ & $\begin{array}{l}\text { Hardness as } \\
\mathrm{CaCO}_{3}\end{array}$ \\
\hline $144 \mathrm{~N} 28 \mathrm{~W} 27 \mathrm{CCBB}$ & 071989 & 7.4 & 187 & 266 & 220 \\
\hline 144N31W25BBDC & 071189 & 7.8 & 103 & 123 & 98 \\
\hline 144N27W05CABA & 072089 & 7.7 & 190 & 211 & 190 \\
\hline 144N26W01BBDA & 072089 & 7.1 & 382 & 467 & 400 \\
\hline $144 \mathrm{~N} 30 \mathrm{~W} 01 \mathrm{ABAB}$ & 072089 & 7.6 & 343 & 353 & 320 \\
\hline $145 \mathrm{~N} 28 \mathrm{~W} 34 \mathrm{CCAC}$ & 071989 & 7.6 & 124 & 164 & 130 \\
\hline $145 \mathrm{~N} 31 \mathrm{~W} 35 \mathrm{CBDA}$ & 071189 & 7.3 & 96 & -- & 93 \\
\hline $145 \mathrm{~N} 27 \mathrm{~W} 36 \mathrm{CBAA}$ & 072089 & 7.0 & 148 & 205 & 160 \\
\hline 145N28W27DDCA & 071989 & 7.9 & 164 & 252 & 190 \\
\hline $145 \mathrm{~N} 30 \mathrm{~W} 24 \mathrm{CDCC}$ & 071289 & 7.4 & 145 & -- & 140 \\
\hline $145 \mathrm{~N} 27 \mathrm{~W} 19 \mathrm{CBCA}$ & 071989 & 7.1 & 116 & 133 & 110 \\
\hline 145N31W19BAAA & 071189 & 7.8 & 208 & 231 & 200 \\
\hline 145N30W19BAAB & 071389 & 7.8 & 239 & 272 & 240 \\
\hline 145N25W18DDDC & 072089 & 7.5 & 256 & 433 & 310 \\
\hline 145N31W15ACB & 071289 & 7.2 & 338 & 392 & 340 \\
\hline 145N31W18BABD & 071189 & 7.7 & 212 & 233 & 210 \\
\hline $145 \mathrm{~N} 29 \mathrm{~W} 08 \mathrm{CDCC}$ & 071289 & 7.9 & 235 & 251 & 230 \\
\hline 145N31W08DAAC & 082290 & 7.7 & 183 & 246 & 200 \\
\hline 145N29W11DACC & 072089 & 7.5 & 159 & 180 & 150 \\
\hline 145N29W09ACAC & 071289 & 8.3 & 184 & 210 & 190 \\
\hline 145N27W04DCCC & 071989 & 8.5 & 75 & 102 & 74 \\
\hline 146N29W31DBDB & 071989 & 8.3 & 84 & 103 & 85 \\
\hline 146N29W33BCDB & 071289 & 8.2 & 189 & 202 & 180 \\
\hline 146N27W35AAAA & 071889 & 7.9 & 190 & 263 & 230 \\
\hline 146N30W34BBBB & 071189 & 7.9 & 110 & 133 & 110 \\
\hline $146 \mathrm{~N} 30 \mathrm{~W} 25 \mathrm{CCCC}$ & 071189 & 7.7 & 132 & 143 & 130 \\
\hline $146 \mathrm{~N} 31 \mathrm{~W} 29 \mathrm{CBBB}$ & 071189 & 7.6 & 252 & 274 & 240 \\
\hline 146N31W21DAAA & 071089 & 7.9 & 192 & 218 & 190 \\
\hline 147N31W22DCCC & 071089 & 7.7 & 226 & 245 & 220 \\
\hline 147N27W14DACC & 071889 & 7.3 & 76 & 106 & 71 \\
\hline 148N27W35BAAD & 071889 & 8.2 & 134 & 160 & 140 \\
\hline
\end{tabular}




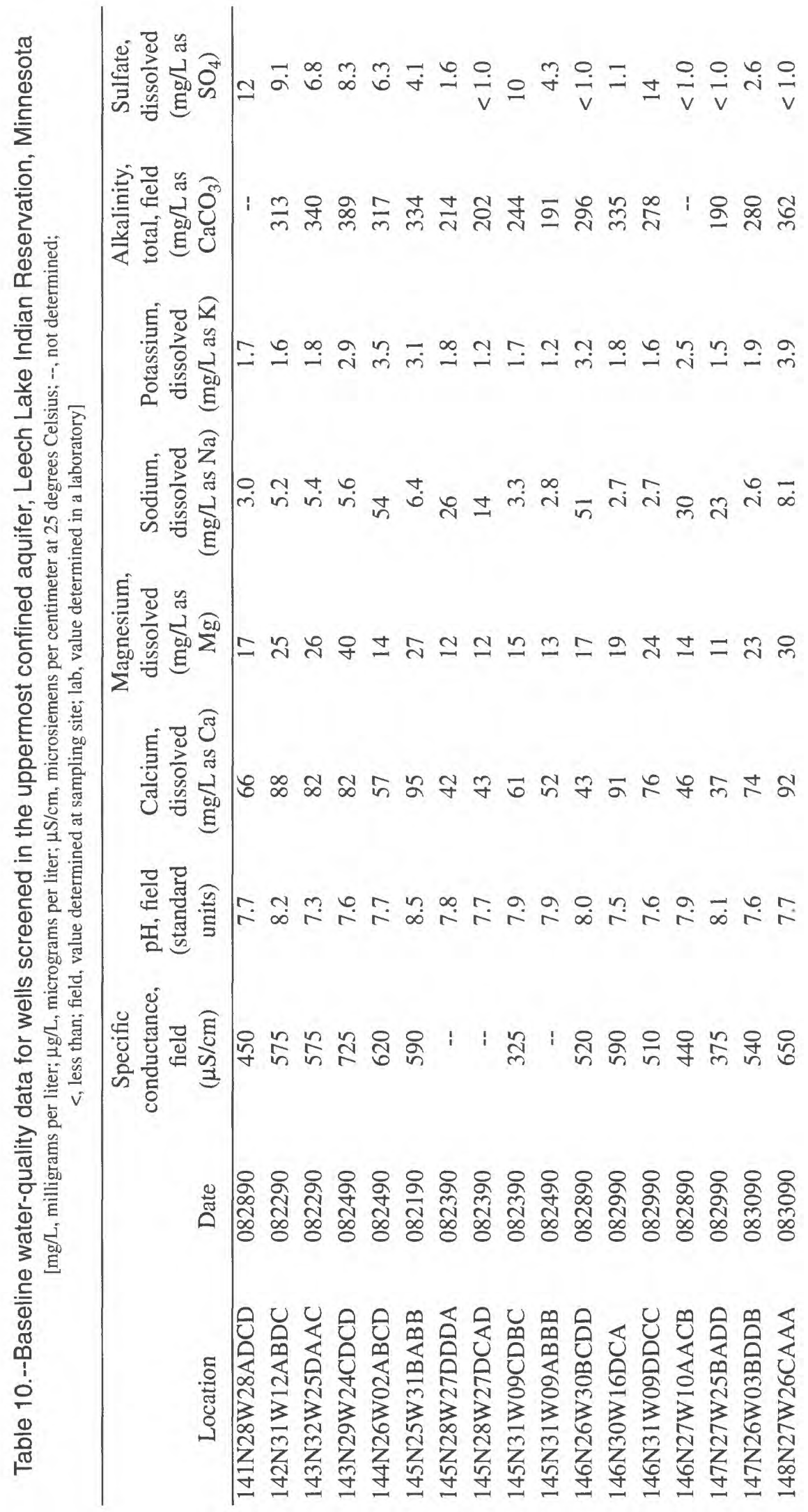




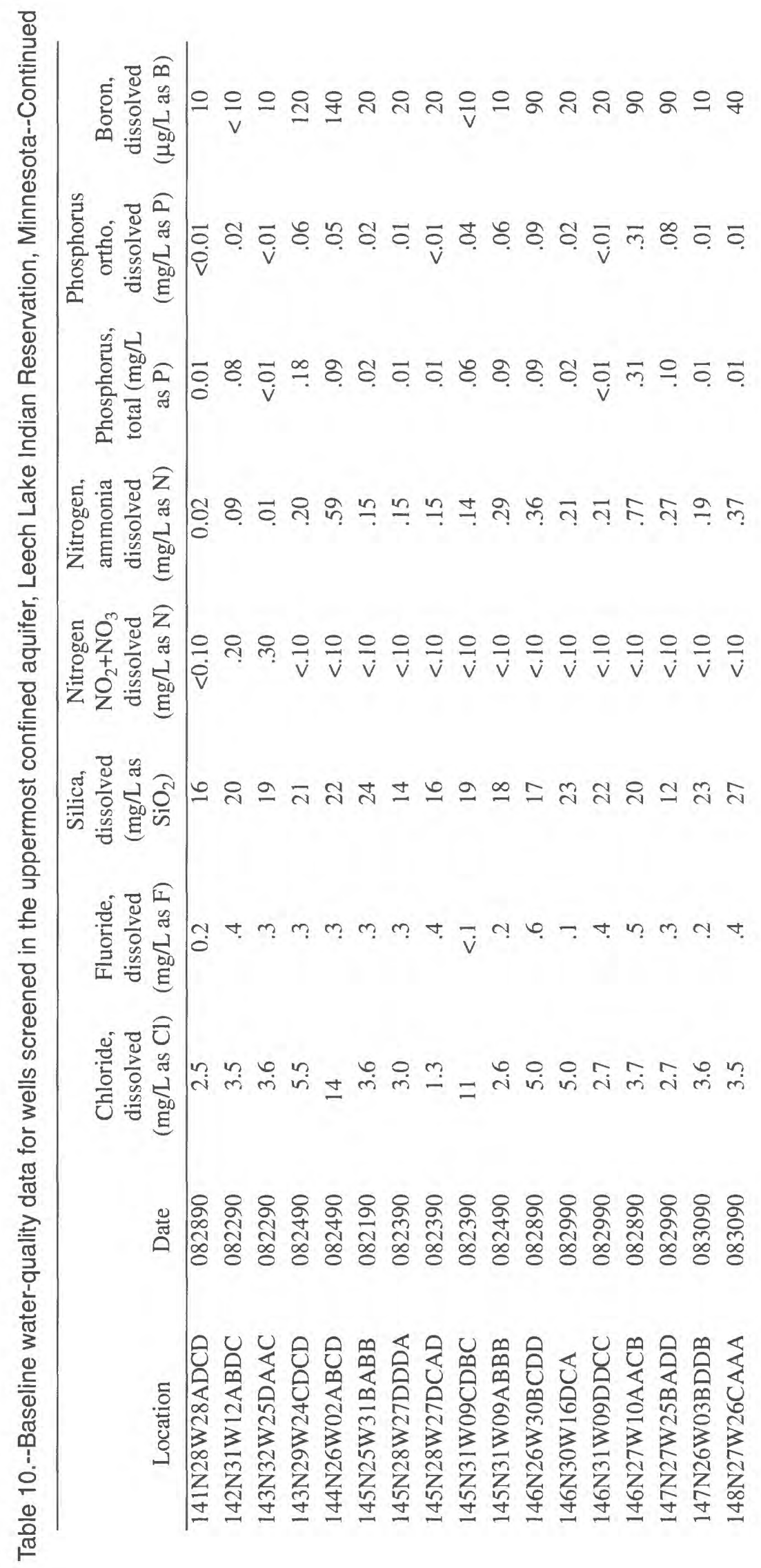




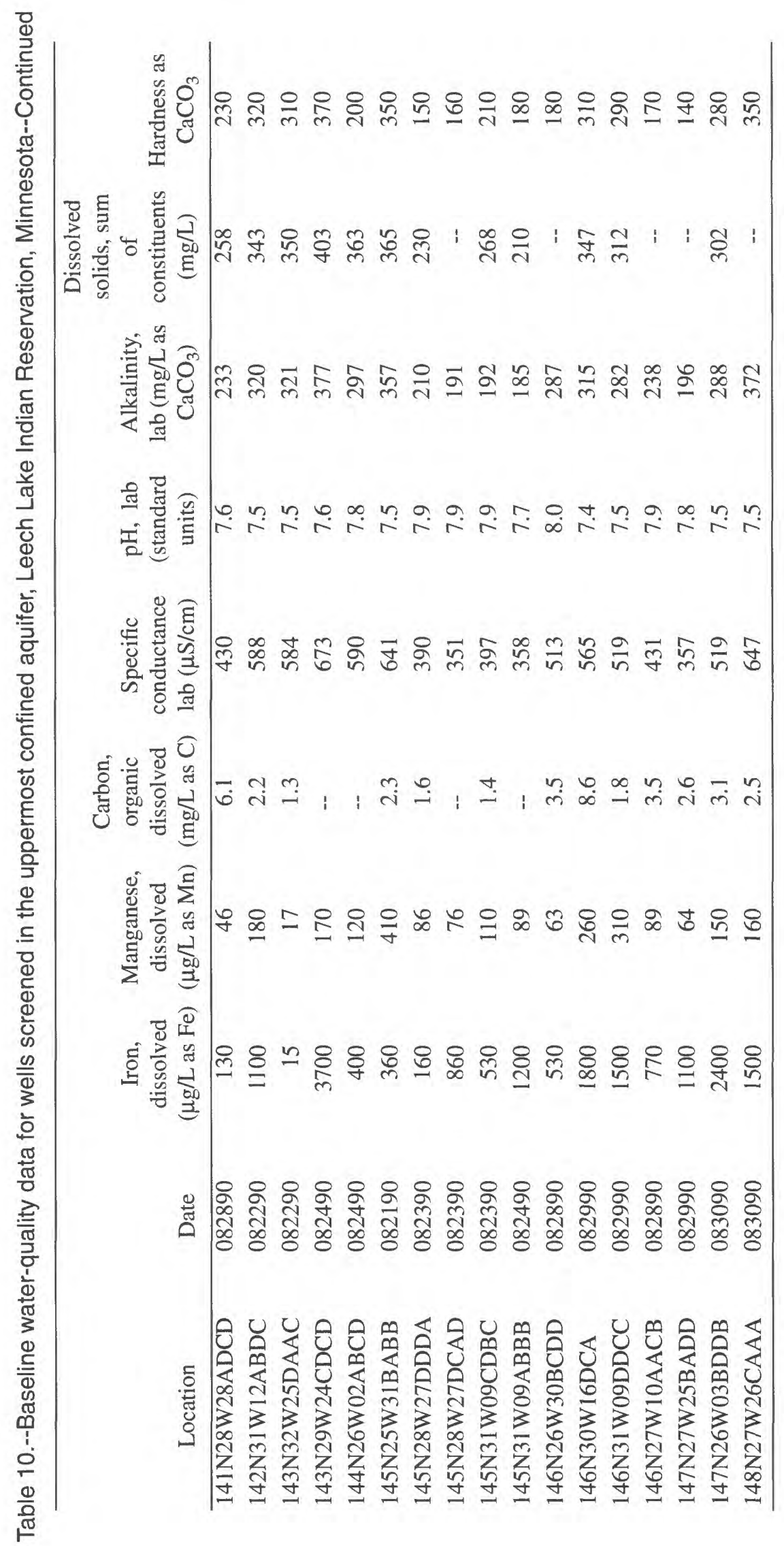

